\title{
Beta Measurements at Department of Energy Facilities
}
L. A. Rathbun
K. L. Swinth
D. L. Haggard

August 1987

Prepared for

the U.S. Department of Energy

Assistant Secretary for

Environment, Safety, and Health

under Contract DE-AC06-76RLO 1830

Pacific Northwest Laboratory

Operated for the U.S. Department of Energy

by Battelle Memorial Institute 


\title{
DISCLAIMER
}

This report was prepared as an account of work sponsored by an agency of the United States Government. Neither the United States Government nor any agency thereof, nor Battelle Mernorial Institute, nor any of their employees, makes any warranty, expressed or implied, or assumes any legal liability or responsibility for the accuracy, completeness, or usefulness of any information, apparatus, product, or process disclosed, or represents that its use would not infringe privately owned rights. Reference herein to any specific commercial product, process, or service by trade name, trademark, manufacturer, or otherwise, does not necessarily constitute or imply its endorsement, recommendation, or favoring by the United States Government of any agency thereof, or Battelle Memorial Institute. The views and opinions of authors expressed herein do not necessarly state or reflect those of the United States Government or any agency thereof, or Battelle Memorial Institute.

\author{
PACIFIC NORTHWEST LABORATORY \\ operated by \\ BATTELLE MEMORIAL INSTITUTE \\ for the \\ UNITED STATES DEPARTMENT OF ENERGY \\ under Contract DE-AC06-76RLO 1830
}

Printed in the United States of America

Available from

National Technical Information Service

United States Department of Commerce

5285 Port Royal Road

Springfield, Virginia 22161

NTIS Price Codes

Microfiche A01

Printed Copy

$\begin{array}{lr}\text { Pages } & \begin{array}{r}\text { Price } \\ \text { Codes }\end{array} \\ 001-025 & \text { A02 } \\ 026-050 & \text { A03 } \\ 051-075 & \text { A04 } \\ 076-100 & \text { A05 } \\ 101-125 & \text { A06 } \\ 126-150 & \text { A07 } \\ 151-175 & \text { A08 } \\ 176-200 & \text { A09 } \\ 201-225 & \text { A010 } \\ 226-250 & \text { A011 } \\ 251-275 & \text { A012 } \\ 276-300 & \text { A013 }\end{array}$


BETA MEASUREMENTS AT DEPARTMENT

OF ENERGY FACILITIES
L. A. Rathbun
K. L. Swinth
D. L. Haggard

August 1987

Prepared for

the U.S. Department of Energy

Assistant Secretary for

Envircnment, Safety, and Hea 1 th

under Contract DE-ACO6-76RLO 1830

Pacific Northwest Laboratory

Richland, Washington 99352 


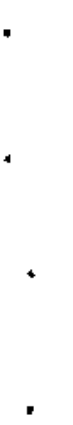

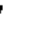


FOREWORD

This report presents measured beta dose rates and spectra at U.S. Department of Energy (DOE) facilities. This and the companion report, "Characteristics of Beta Detection and Dose Measurement at Department of Energy Facilities" (Mulvehill et al. 1987), present information to characterize the beta fields and protection practices at DOE facilities.

Beta measurements are technically difficult, and innovative efforts must be expended to improve their accuracy. The most important problem is that the beta dosimetry and instrumentation used are highiy dependent on energy, angular incidence, and source geometry. Many health protection specialists believe that beta exposures are adequately controlled because beta-to-photon ratios are assumed to be low. This assumption is not always valid as the data in this report indicate. Significant beta doses exist where personnel are exposed to mixed fission products; for example, chemical reprocessing plants, reactor accidents, or where uranium metals or powders are processed. Consequentiy, accurate measurements of beta fields are important to effect proper control of beta exposures to workers.

This report is part of an effort to increase the DOE awareness of this technically difficult area of radiation protection. Findings and recommendations for improvements are noted. A cooperative effort among the various DOE contractors is needed to improve upon the present situation, and your comments and suggestions will be welcomed.

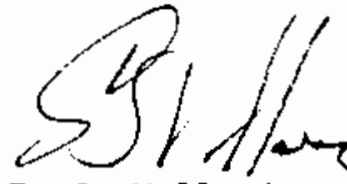

E. J. Vallario

Acting Director

Radiological Controls Division

Office of Nuclear Safety

U.S. Department of Energy 


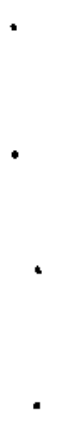

,

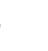

. 
SUMMARY

BACKGROUND

As part of a program to upgrade beta measurements at U.S. Department of Energy (DDE) facilities, Pacific Northwest Laboratory (PNL) performed a twostep process to characterize the current beta measurement practices at DOE facilities. First, PNL issued a survey questionnaire on beta measurement practices to DOE facilities, the results of which have been documented. (a) Second, PNL measured beta doses and spectra at seven selected DOE facilities and compared selected measurement techniques in the facility environment. This report documents the results of the radiation field measurements and the comparison of measurement techniques at the seven facilities.

Data collected by PNL included beta dose and spectral measurements at seven DOE facilities that had high beta-to-gamma ratios. The measurement systems used were a silicon surface barrier spectrometer, a plastic scintillator spectrometer, and a multielement beta dosimeter. Other dosimeters and survey meters representative of those used at DOE facilities or under development were also used for comparison.

Field spectra were obtained under two distinct conditions. In the first case, silicon- and scintillation-based spectrometer systems were used under laboratory conditions where high beta-to-gamma dose ratios made the beta spectra easier to observe and analyze. In the second case, beta spectrometers were taken into actual production and maintenance areas of DOE facilities. Some of the facilities had large quantities of unshieided uranium in various forms leading to high beta-to-gamma dose ratios. However, where fission products were found or where uranium was shielded, low beta-to-gamma dose ratios made beta spectra difficult to interpret. Low-energy (1ess than $200 \mathrm{keV}$ ) beta fields caused additional difficulties in interpretation due to the nonlinear energy response of the beta spectrometers at low energies.

(a) Mulvehill, J. M., L. W. Brackenbush, K. L. Swinth, and E. J. Vallario. 1987. Characteristics of Beta Detection and Dose Measurements at Department of Energy Facilities. PNL-5960, Pacific Northwest Laboratory, Richland, Washington. 
At facilities where mixed fission products are present, handling and control procedures to limit internal exposures and exposure to penetrating radiations are also effective in controlling beta dose rates to workers. At facilities where large amounts of uranium $\left({ }^{234} \mathrm{Th}-{ }^{234 \mathrm{~m}_{\mathrm{Pa}} \text { and }}{ }^{231} \mathrm{Th}\right)$ are handled in the metal form, the observed beta dose rates were higher.

Analyses of beta and gamma spectra showed that ${ }^{234} \mathrm{Th}-{ }^{234 \mathrm{~m}} \mathrm{~Pa},{ }^{231} \mathrm{Th}$, ${ }^{137} \mathrm{Cs}$, and ${ }^{90} \mathrm{Sr} /{ }^{90} \mathrm{Y}$ were the major nuclides contributing to beta doses at the facilities visited. Beta doses from other fission products and ${ }^{60}$ Co were also measured, but the potential for exposure was less significant.

Because of superior handling and control procedures at facilities with mixed fission products, beta dose rates to those workers were lower than beta dose rates to workers at facilities where unshielded ${ }^{234} \mathrm{Th}-{ }^{234 m} \mathrm{~Pa}$ and ${ }^{231} \mathrm{Th}$ existed. In the latter facilities, rapid accumulation of black uraniumdecay product dust on the outside of workers' gloves (leather gloves worn for mechanical protection) and the opportunity for glove interiors to become contaminated made dose rates to the hands potentially large. Dose rates greater than $800 \mathrm{mrad} / \mathrm{h}$ were measured inside one glove.

The beta dose rates determined with five different commercial survey meters were typically slightly lower than the accepted values from spectral measurements when the center of the entrance window was taken as the reference point and correction factors were applied for energy and geometry. However, if a single correction factor was used without consideration of beta energies or geometry, measured beta doses could be in error by a factor of 2 . In extreme instances, the measured doses could be two orders of magnitude lower than the actual doses.

\section{CONCLUSIONS}

The analysis of the measurements and comparison of measurement techniques led to the following five major conclusions:

- Beta survey meters should be calibrated for beta energies and detector-source geometries similar to those encountered in the facility. 
- The best results from survey meters were obtained when the center of the sensitive volume was used as the reference point. However, such a reference point is not useful when measured dose rates are required near $(<5 \mathrm{~cm})$ the source.

- Tests of a prototype beta-plus-gamma dose rate meter developed at the Idaho National Engineering Laboratory (INEL) showed superior performance based on agreement with our standard techniques.

- Doses measured by many dosimeters used at DOE facilities were only one-half of the doses measured by PNL's eight-element dosimeter.

- When a thin window covered the beta measuring element of a tested dosimeter, the response was much closer ( $80 \%$ to $90 \%$ ) to that of PNL eight-element dosimeter, provided that an appropriate algorithm was used to resolve the dose components.

\section{RECOMMENDATIONS}

Based on the results of the site measurements and the analysis of measurement techniques, the following list of recommendations was developed.

- The INEL prototype beta-plus-gamma dose rate meter should be further developed.

- Further studies of detector response at energies below $200 \mathrm{keV}$ should be undertaken to determine the degree of detector nonlinearity and its influence on dose calculations.

- Studies are needed on the influence of backscatter from detectors and detector windows on beta spectra and beta dose calculations.

- Further studies should be performed on the eight-element dosimeters to determine their response in mixed fields dominated by low-energy photons.

- A dosimeter similar to the eight-element unit, but using stacked elements should be developed. This would eliminate the concern about the spatial response of the present multielement dosimeter and permit the study of spatial variations in radiation fields. 
- Dosimeters used in beta fields at DOE facilities should have a thin window (less than $20 \mathrm{mg} / \mathrm{cm}^{2}$ ) over the beta element.

- Conventional $235 \mathrm{mg} / \mathrm{cm}^{2}$ TLDs should be replaced by thin TLDs $\left(17 \mathrm{mg} / \mathrm{cm}^{2}\right)$ in dosimeters used to monitor beta exposures.

- Dosimeters should be caljbrated to beta energies similar to those encountered in the work areas. Yttrium-90 calibrations provide a beta spectrum with too high an average energy for many applications.

- The influence of source geometry and source-detector distance on measurements should be known for each instrument used in a facility. Whenever possible, measurements should be made to determine the correction factors.

- Personnel should be trained to use correction factors for source energy, source geometry, and source-to-detector distance on dose rate measurements.

- The variation in response of instruments with beta energy and angle of incidence should be documented.

- A modified ionization chamber instrument with a large-area, shallow chamber should be available for beta-dose-rate measurements.

- Workers who handle uranium metat products and associated processing materials should be made aware of the potentially high contact beta dose rates.

- Radiation protection procedures should be improved for workers in facilities where uranium decay products present beta dose problems. Contamination control, protective clothing, and dosimeter placement should be addressed. 


\section{ACKNOWLEDGMENTS}

The authors would like to acknowledge the cooperation of the health physics staff at the various DOE sites who permitted us to make measurements at their facilities. Their comments and assistance will serve to improve beta programs at all DOE facilities. The efforts of $M$. Cross in report assembly and of $S$. Ennor in report editing are gratefully acknowledged. 
. 


\section{CONTENTS}

FOREWORD

SUMMARY

\section{v}

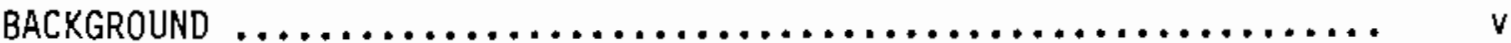

CONCLUSIONS $\ldots \ldots \ldots \ldots \ldots \ldots \ldots \ldots \ldots \ldots \ldots \ldots \ldots \ldots \ldots \ldots \ldots \ldots \ldots \ldots \ldots$

RECOMMENDATIONS $\ldots \ldots \ldots \ldots \ldots \ldots \ldots \ldots \ldots \ldots \ldots \ldots \ldots \ldots \ldots \ldots \ldots \ldots \ldots \ldots \ldots \ldots$

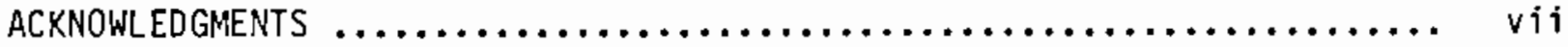

1.0 INTRODUCTION $\ldots \ldots \ldots \ldots \ldots \ldots \ldots \ldots \ldots \ldots \ldots \ldots \ldots \ldots \ldots \ldots \ldots \ldots$

2.0 METHODOLOGY $\ldots \ldots \ldots \ldots \ldots \ldots \ldots \ldots \ldots \ldots \ldots \ldots \ldots \ldots \ldots \ldots \ldots \ldots \ldots \ldots$

2.1 MEASUREMENT SYStEMS $\ldots \ldots \ldots \ldots \ldots \ldots \ldots \ldots \ldots \ldots \ldots \ldots \ldots \ldots \ldots$

2.1.1 Silicon Surface Barrier Spectrometer System ......... 4

2.1.2 Plastic Scintillator Beta Spectrometer ........... 5

2.1.3 Germanium Spectrometer .................... 6

2.1.4 Multielement Beta Dosimeter .................. 7

2.1 .5 0ther Measurement Devices .................... 10

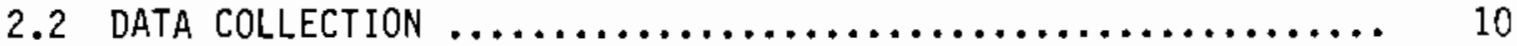

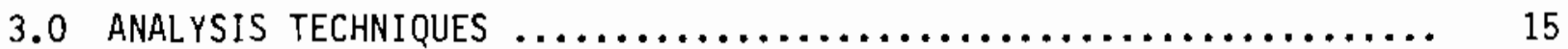

3. I SILICON AND PLASTIC SCINTILLATOR DETECTORS $\ldots \ldots \ldots \ldots \ldots \ldots \ldots$

3.1.1 Beta Detection and Response $\ldots \ldots \ldots \ldots \ldots \ldots \ldots \ldots \ldots$

3.1.2 Photon Response ......................... 19

3.1.3 Average Beta Energies ...................... 19

3.1 .4 Dose Calculations $\ldots \ldots \ldots \ldots \ldots \ldots \ldots \ldots \ldots \ldots \ldots \ldots . \ldots \ldots$

3.1 .5 Calibration $\ldots \ldots \ldots \ldots \ldots \ldots \ldots \ldots \ldots \ldots \ldots \ldots \ldots \ldots \ldots \ldots$

3.2 PACIFIC NORTHWEST LABORATORY MULTIELEMENT DOSIMETER . ....... 22

3.2.1 Thermoluminescent Chip Readout and Dose .......... 22 


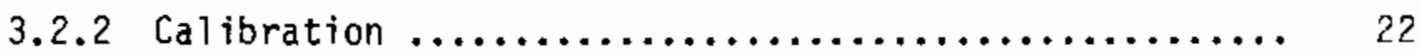

3.3 COMMERCIAL DOSIMETERS AND OTHER DOSIMETERS $\ldots \ldots \ldots \ldots \ldots \ldots .24$

3.4 SURVEY METERS $\ldots \ldots \ldots \ldots \ldots \ldots \ldots \ldots \ldots \ldots \ldots \ldots \ldots \ldots \ldots \ldots \ldots \ldots \ldots \ldots \ldots, 25$

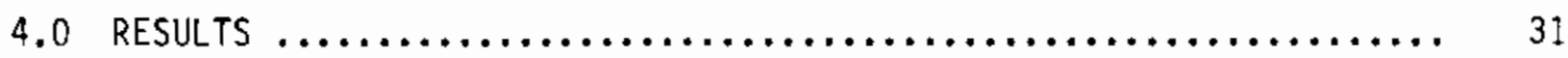

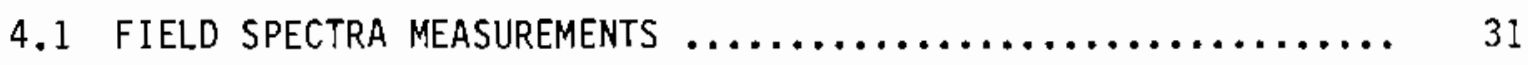

4.1.1 Site A: Separations Facility .................. 31

4.1.2 Site B: Fuel Fabrication Facility ............... 37

4.1 .3 Site $C:$ Separations Facility ................... 39

4.1.4 Site $\mathrm{D}$ : Uranium Facility $\ldots \ldots \ldots \ldots \ldots \ldots \ldots \ldots \ldots, 56$

4.1 .5 Site E: Uranium Facility $\ldots \ldots \ldots \ldots \ldots \ldots \ldots \ldots \ldots, 56$

4.1.6 Site F: Laboratory and Fuel Processing Facility .... 58

4.1.7 Site $G:$ Plutonium Production Reactor ............ 62

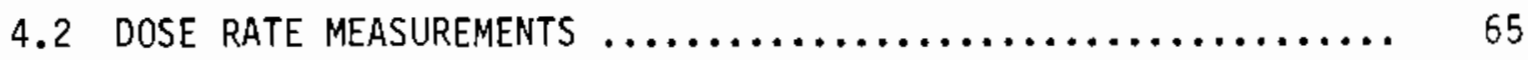

4.2.1 Site A: Separations Facility $\ldots \ldots \ldots \ldots \ldots \ldots \ldots \ldots, 65$

4.2.2 Site B: Fuel Fabrication Facility .............. 67

4.2 .3 Site $C$ : Separations Facility .................... 69

4.2.4 Site D: Uranium Facility $\ldots \ldots \ldots \ldots \ldots \ldots \ldots \ldots, 70$

4.2.5 Site E: Uranium Facility $\ldots \ldots \ldots \ldots \ldots \ldots \ldots \ldots \ldots \ldots \ldots \ldots \ldots \ldots, 71$

4.2.6 Site F: Laboratory and Fuel Processing Facility .... 73

4.2.7 Site G: Plutonium Production Reactor .............. 75

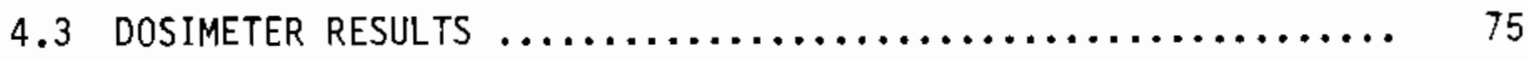

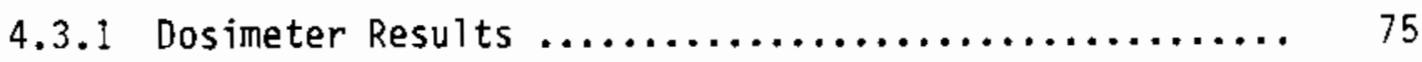

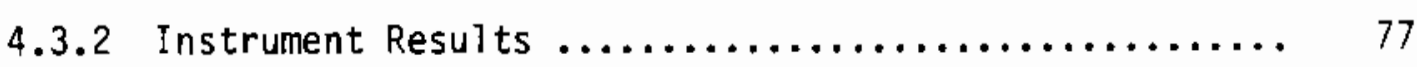

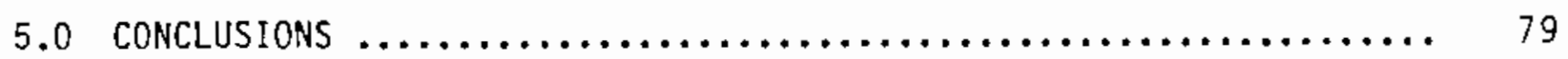

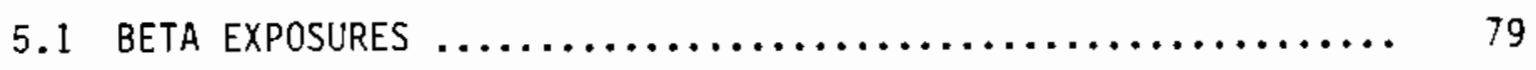




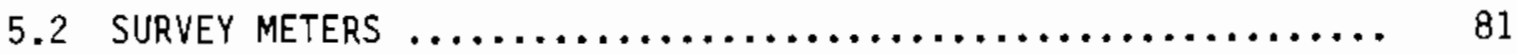

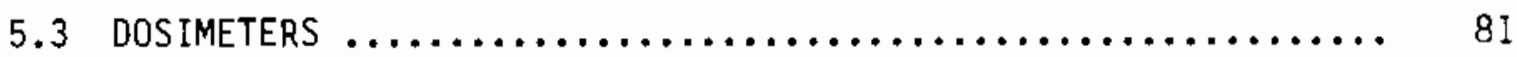

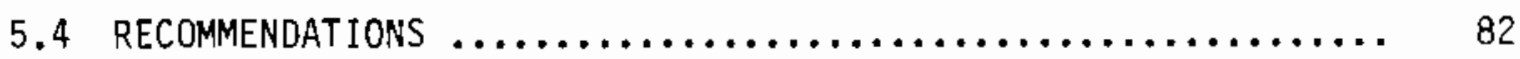

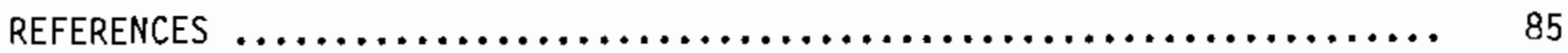




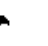

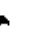

. 
FIGURES

1 Equipment Arrangement for Beta and Photon Spectrometers $\ldots . . \ldots \ldots$... 3

2 Cesium-137 Beta and Conversion Electron Spectrum Collected

with a Siticon Surface Barrier Spectrometer .................... 4

3 Backscatter of Electrons from Selected Materials ............... 6

4 Eight-Element Dosimeter $\ldots \ldots \ldots \ldots \ldots \ldots \ldots \ldots \ldots \ldots \ldots \ldots \ldots \ldots, 8$

5 Surface Barrier Detector and Liquid Sample $\ldots \ldots \ldots \ldots \ldots \ldots, 12$

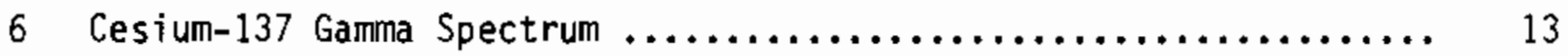

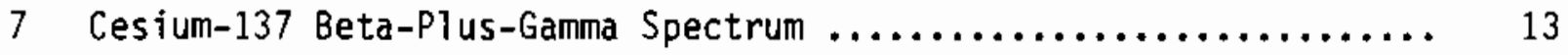

8 Comparative Detector Responses to Laboratory Beta Sources ....... 17

9 Examples of Beta-Ray Spectra, Illustrating the Wide

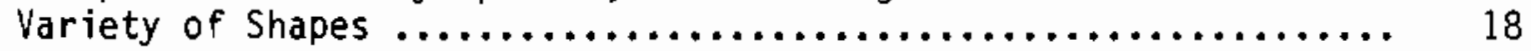

10 Reversed Biassed Silicon Junction Beta Dosimeter ............... 20

11 Beta Spectrum for the First Process Sample at $30 \mathrm{~cm} \ldots \ldots . . . . . .32$

12 Beta-PIus-Gamma Spectrum for the First Process Sample

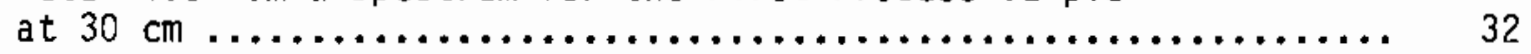

13 Beta Spectrum for the First Waste Sample at $30 \mathrm{~cm} \ldots \ldots \ldots \ldots . . . . .33$

14 Beta-Plus-Gamma Spectrum for the First Waste Sample at $30 \mathrm{~cm} \ldots . .33$

15 Combined Beta-Plus-Gamma Spectrum from the Second Process

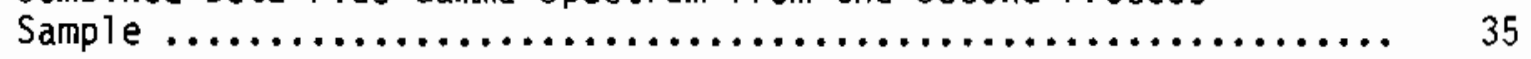

16 Beta-0niy Spectrum from the Second Process Sample ............. 35

17 Germanium Photon Spectrum from the Second Process Sample ........ 36

18 Beta-Plus-Ganma Spectrum from the Second Waste Sample $\ldots . . . \ldots . .36$

19 Beta-Only Spectrum from the Second Waste Sample $\ldots \ldots \ldots \ldots \ldots \ldots . . . .637$

20 Beta-Plus-Gamma Spectrum for the 1.25\%-Enriched Fuel Element ..... 38

21 Gamma Spectrum for the 1.25\%-Enriched Fuel Element $\ldots \ldots \ldots \ldots \ldots . .38$

22 Beta Spectrum for the 1.25\%-Enriched Fuel Element .............. 39 
23 Germanium Gamma Spectrum for the 1.25\%-Enriched Fuel Element .... 40

24 Germanium Gamma Spectrum for the 0.95\%-Enriched Fuel Element .... 40

25 Beta-Plus-Gamma Spectrum for the Sample from Tank 105AW ........ 41

26 Beta Spectrum for the Sample from Tank 105AW .............. 42

27 Beta-Plus-Gamma Spectrum for the Sample from Tank 107AN ........ 43

28 Beta Spectrum for the Sample from Tank 107 AN .............. 43

29 Beta-Plus-Gamma Spectrum for the Sample from Tank 105AN ........ 44

30 Beta Spectrum for the Sample from Tank 105AN ............... 45

31 Beta-PTus-Ganma Spectrum for the Sample from Tank $102 A Z \ldots \ldots \ldots .45$

32 Beta Spectrum for the Sample from Tank $102 A Z \ldots \ldots \ldots \ldots \ldots \ldots$

33 Gamma Spectrum for the Sample from Tank 105 AN77 ........... 46

34 Beta-Plus-Gamma Spectrum for the Sample from Tank 105AN154 ..... 47

35 Beta Spectrum for the Sample from Tank 105 AN154 ............. 47

36 Beta Spectrum for the Sample from Tank 104 AN272 ............ 48

37 Beta-Plus-Gamma Spectrum for the Sample from Tank 104AN272 ..... 48

38 Beta-Plus-Gamma Spectrum for the Sample from Tank 102AW ....... 49

39 Beta-Oniy Spectrum for the Sample from Tank 102AW ........... 50

40 Beta Spectrum for the End Cut from a Uranium Billet .......... 51

41 Beta Spectrum for the Top of a Uranium Electrode Pour ......... 51

42 Beta Spectrum at $1 \mathrm{~m}$ from a Charge Makeup Crucible ........... 5 ?

43 Beta Spectrum at $1.9 \mathrm{~cm}$ from a Charge Makeup Crucible ......... 5 ?

44 Corrected Beta Spectrum at $1.9 \mathrm{~cm}$ from a Charge Makeup Crucible .. 53

45 Germanium Gamma Spectrum for an End Cut from a Uranium Billet .... 54

46 Germanium Gamma Spectrum for a Fresh Cast. Electrode .......... 54

47 Germanium Gamma Spectrum for an Arc Melt Cast ............. 55

48 Germanium Gamma Spectrum for a Charge Makeup Crucible ......... 55 
49 Beta Spectrum $15 \mathrm{~cm}$ Above a Uranium Crucible $\ldots \ldots \ldots \ldots \ldots \ldots \ldots . .65$

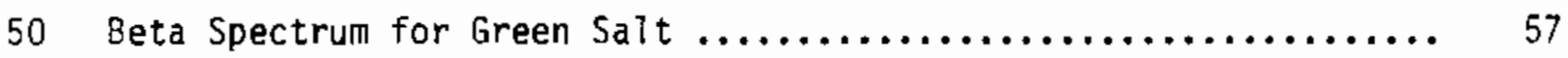

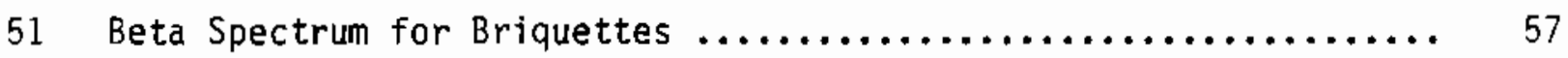

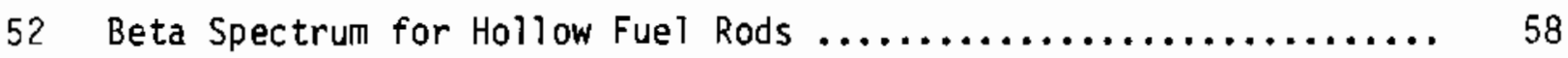

53 Beta Spectrum for a Graphite Crucible at $0.6 \mathrm{~cm} \ldots \ldots . . . . . . . .59$

54 Beta Spectrum for the Outside of a Used Glove ................ 59

55 Beta Spectrum for the Inside of a Used Glove $\ldots \ldots \ldots \ldots . . . \ldots . .60$

56 Beta Spectrum for a Briquette at $0.6 \mathrm{~cm}$ from the Detector ....... 60

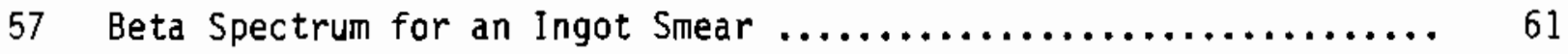

58 Beta Spectrum for a Fuel Element at $0.6 \mathrm{~cm}$ from the Detector ..... 61

59 Beta Spectrum for a Contaminated Soil Sample .................. 62

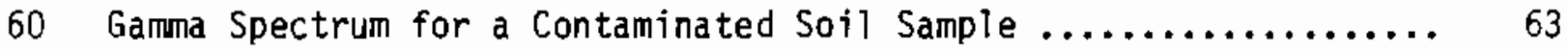

61 Beta Spectrum at $60 \mathrm{~cm}$ from a BTister Port .................. 63

62 Gamma Spectrum at $60 \mathrm{~cm}$ from a Blister Port .................. 64

63 Beta-Plus-Gamma Spectrum for FueT-Tube Caps $\ldots \ldots \ldots \ldots \ldots \ldots \ldots .64$

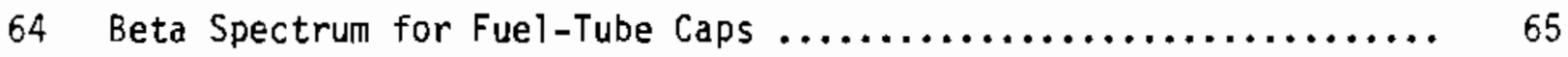




\section{TABLES}

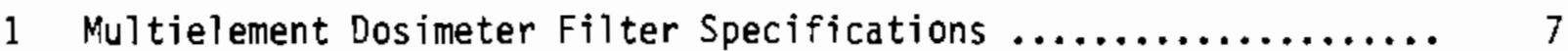

2 Characteristics of Beta CaTibration Sources .................. 23

3 Calibration Factors for Two-E]ement Dosimeters ................ 25

4 Measured Factor for How Much a LiF TLD Would Underestimate the Actual Beta Dose Relative to the PTB $90 \mathrm{Sr} / 90$ Dose ........... 26

5 Calibration Factors for Survey Instruments $\ldots \ldots \ldots \ldots \ldots \ldots \ldots . . .28$

6 Examples of "Cutie Pie" (Instrument C) Correction Factors

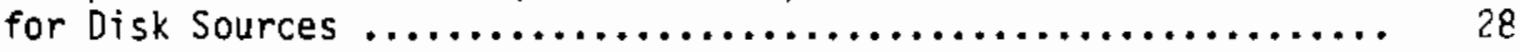

7 Examples of "Cutie Pie" (Instrument C) Correction Factors

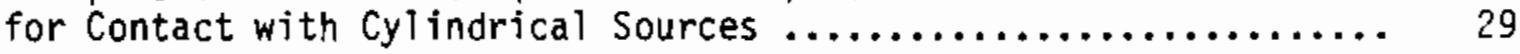

8 Site A Beta Dose Rates Measured with Spectrometers

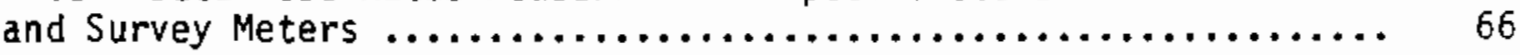

9 Site B Dose Rates from a $0.95 \%$-Enriched Fuel Element ............ 68

10 Site $B$ Dose Rates from a $1.25 \%$-Enriched Fuel Element ........... 68

II Dose Rates in Various Locations in the Uranium Fuel Fabrication Facility ....................................... 69

12 Site C Dose Rates for Waste Tank Samples Measured with CP "C" .... 70

13 Site D Beta Dose Rates Measured with Spectrometers

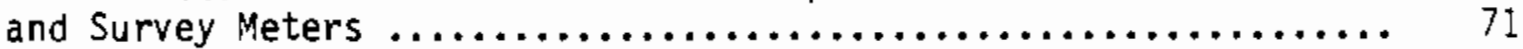

14 Field Site E Beta Dose Rates Measured with Spectrometers

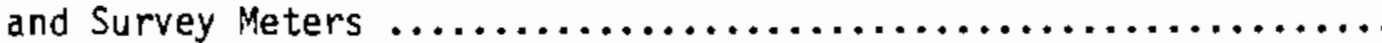

25 Second Site E Beta Dose Rates Measured with Spectrometer and Survey Meter $. . . \ldots \ldots \ldots \ldots \ldots \ldots \ldots \ldots \ldots \ldots \ldots \ldots \ldots, 73$

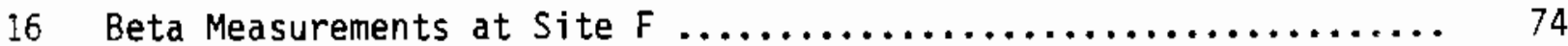

17 Response of Dosimeters to Beta Radiation at Department of Facilities .......................................... 76

18 Response of Instruments to Beta Radiation at Department of Energy Facitities 


\subsection{INTRODUCTION}

Health physicists and health physics researchers need a good working knowledge of the beta spectra encountered by personnel at U.S. Department of Energy ( $D O E$ ) facilities to ensure that personnel dosimeters and survey instruments are properly calibrated, designed, and used. Such information is important for the accurate measurements of personnel beta doses. In many cases, health physicists have assumed low beta-to-gamma ratios. Thus, beta (nonpenetrating) doses have not been considered the limiting factor in radiation exposures because permissible skin doses are three times the whole body limit. Plant modifications, inspections, maintenance, and repair may require workers to enter radiation environments where beta-to-gamma ratios are large. Then accurate monitoring of the dose equivalent to the skin and lens of the eye from beta radiation requires use of techniques different from those used in routine monitoring of the whole body dose equivalent.

In order to improve beta measurement capabilities at DOE facilities, one must first characterize the current practices. The characterization must include an assessment of current measurement practices and an assessment of the beta spectra and dose rates encountered at facilities. As the first step in characterization, a questionnaire was issued to survey the beta measurement practices at DOE facilities, and the survey results were analyzed (Mulvehili et a 1. 1987). The second step involved onsite measurements and a comparison of measurement techniques.

Pacific Northwest Laboratory (PNL) measured beta doses and spectra at seven DOE facilities. Thirty field locations, eleven liquid samples, and three wipe samples were evaluated with spectrometers and muttielement dosimeters. ATso, beta monitoring instruments and dosimeters used by plant health physics staffs were evaluated at several of the sites to compare their beta dose measurements with the PNL measurements. Measurements were also made with experimentai dosimeters and instruments for evaluation of their perfomance in 
an operational environment. This report presents the results of the measurements of radiation fields made at seven DOE facilities that had high ratios of beta-to-gamma dose rates and discusses the measurement techniques.

Section 2.0 describes the methodology used to obtain the data. Detailed descriptions of the measurement systems are presented. The methods used to collect the data in the field are discussed. A description of data analyses, including dosimeter and instrument responses and calibration, is contained in Section 3.0. The study findings are presented and discussed in section 4.0. Conclusions and recommendations based on the study findings are presented in Section 5.0 . 


\subsection{METHODOLOGY}

This section describes the instrumentation and dosimeters used to measure beta radiation at selected DOE facilities. The measurement systems are documented below. Data collection and analysis procedures are described.

\subsection{MEASUREMENT SYSTEMS}

The measurement systems selected for this study were the silicon surface barrier spectrometer system (Fox and Borkowski 1962), the plastic scintillator system (Wohn et a1. 1972), the germanium photon spectrometer system, and the multielement beta dosimeter (Scherpelz, Endres, and Rathbun 1983). These systems are described below. The equipment arrangement used for the germanium photon and silicon surface barrier spectrometers is the same and is shown in Figure 1. The arrangement for the plastic scintillator is also the same except that the preamplifier is not used.

Initially the silicon surface barrier detector was used as the spectrometer. It could measure the full energy range up to $2 \mathrm{MeV}$ at dose rates of several hundred mrad per hour, and it was sufficiently rugged for use in the field. Later it was found that the plastic scintillation detector provided more accurate spectral measurements at low energies due to lower backscatter. Thereafter the plastic scintillator was used unless high dose rates dictated the use of the surface barrier detector.

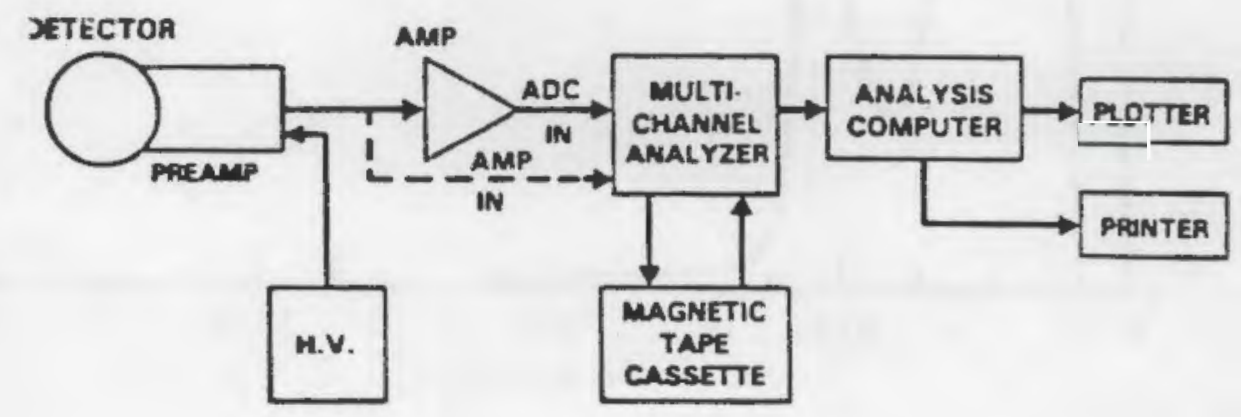

FIGURE 1. Equipment Arrangement for the Beta and Photon Spectrometers 


\subsubsection{Silicon Surface Barrier Spectrometer System}

The silicon surface barrier spectrometer system used a $100-\mathrm{mm}^{2}$ circular detector that was depleted to a depth of $5 \mathrm{~mm}$ at a bias of $1800 \mathrm{~V}$. The detector was mounted, via a rear high-voltage mount, on a low-noise, chargesensitive preamplifier. The detector was enclosed within a light-tight cardboard tube with two, 0.006-mm-thick, aluminized Mylar windows. Cables for the signal, bias voltage, and preamplifier power connected the preamplifier to a multichannel analyzer (MCA) containing an amplifier, bias voltage source, and preamplifier power source. The spectral data were collected with the MCA and stored on magnetic tape in a cassette recorder. Figure 2 illustrates a spectrum taken with the silicon detector showing the beta spectrum and conversion electrons from a ${ }^{137}$ Cs source.

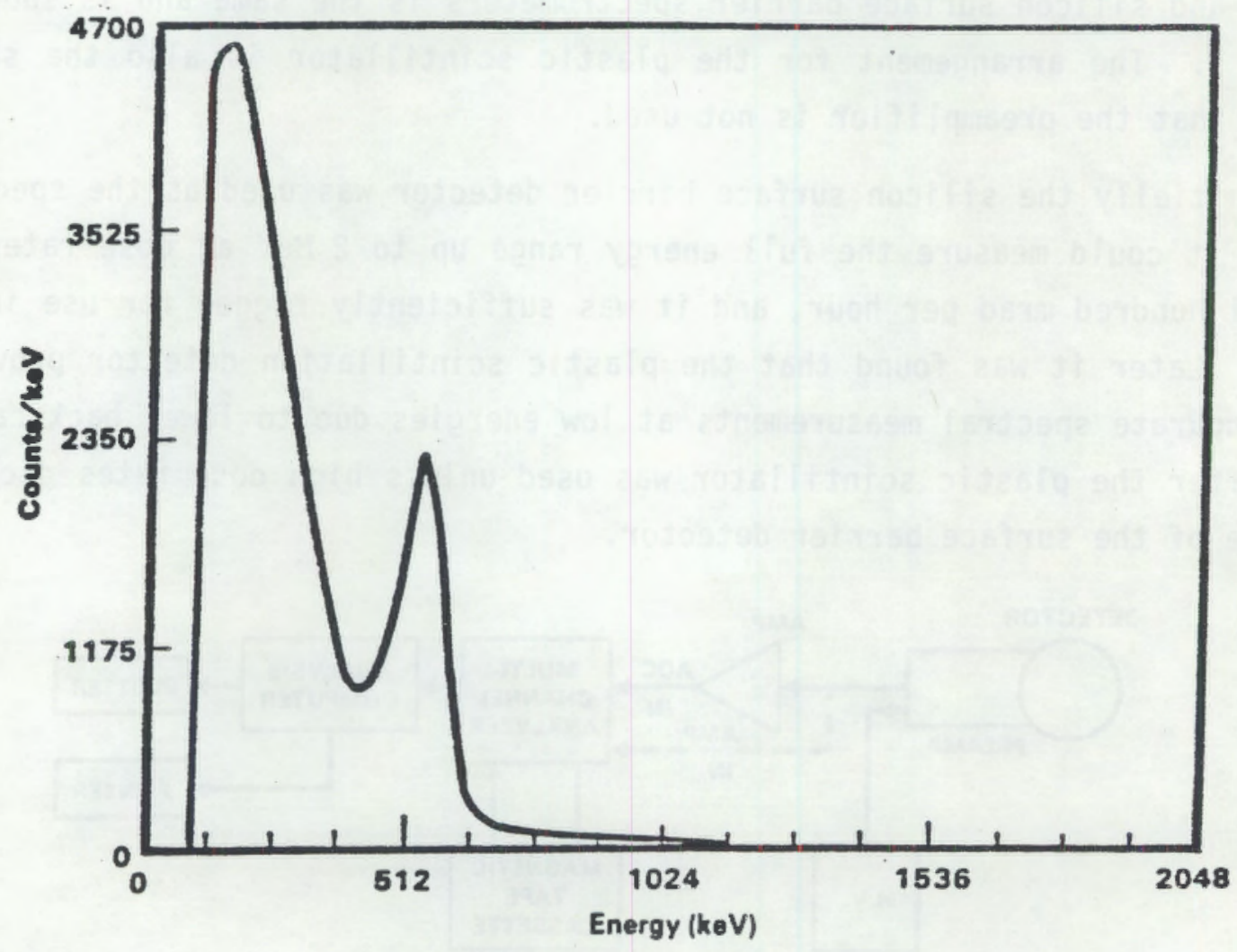

FIGURE 2. Cesium-137 8eta and Conversion Electron Spectrum Collected with a Silicon Surface Barrier Spectrometer 


\subsubsection{Plastic Scintillator Beta Spectrometer}

A plastic scintillator detector was used for measuring low-dose-rate field spectra. It had a diameter of $5.08 \mathrm{~cm}$ and a thickness of $2.54 \mathrm{~cm}$. The detector and a $1-\mathrm{cm}$-thick, nonscintillating light guide were optically coupled to a photomultiplier tube, the base of which incorporated a voltage divider network. The scintillator was fitted with a 0.003-mm, aluminized Mylar window.

The main problem with the plastic scintillator (and the silicon detector) is that they cannot accurately measure low-energy electron (less than $200 \mathrm{keV}$ ) fields. This is because both detectors must be covered with a metallic film to prevent interference from ordinary light. The metallic film prevents penetration of low-energy electrons. Also, if a light leak occurs, the low-energy portion of the spectrum is affected.

A phenomenon, called backscattering, occurs when a beta particle entering a detector undergoes sufficient deflection so that it re-emerges from the same surface through which it entered. The backscattered beta particles do not deposit all their energy in the detector, and therefore the detector will not measure the total energy of the original beta particle.

Backscatter for selected materials is shown in Figure 3, where $T$ is the energy of the incident beta particle and $n$ is the fraction of beta particles backscattered relative to the total number incident. The backscatter for silicon (not shown) would be slightly greater than the backscatter for aluminum, based on atomic numbers of 13 and 14 for aluminum and silicon, respectively. Backscatter is a problem for silicon even without a metallic window. The backscatter is much worse at lower beta energies than at higher energies. Based on Figure 3, the backscatter for plastic scintillators does not appear to be serious. However, the graph in Figure 3 applies only to normally incident beta particles. Information regarding the backscatter for beta particles that enter plastic at shallow angles is not readily available in the literature. It should be noted that plastic is very similar to human tissue for purposes of backscatter. Therefore, beta particles backscattered from the surface of plastic would similariy not deposit energy in the basal layer of skin. 


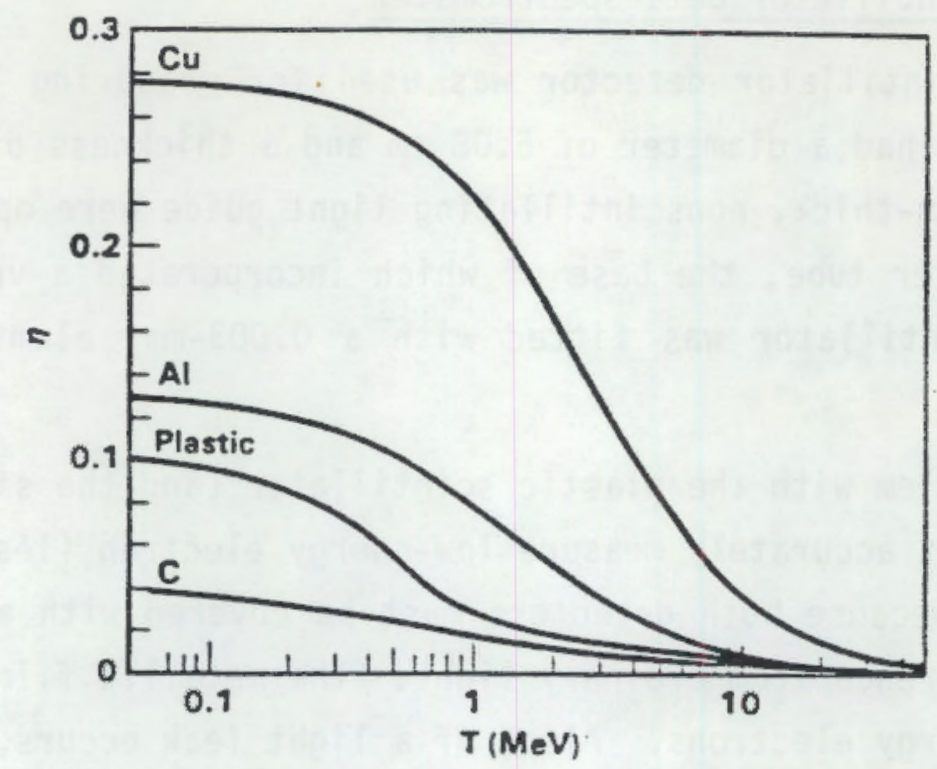

FIGURE 3. Backscatter of Electrons from Selected Materials

The backscatter from plastic scintillators is primarily of importance when spectra obtained with the scintillator are compared with theoretical spectra or when doses are compared with ion-chamber measurements. Based on preliminary studies at PNL, it appears that the backscatter (outscatter) for low-energy beta particles incident at shallow angles is much more severe than Figure 3 would indicate. Additional studies are needed to resolve this question.

Simons et a1. (1982) and Birks (1964) have reported that the plastic scintillator has a nonlinear response at low, beta particle energies (less than $125 \mathrm{keV}$ ). This response is thought to be due to quenching from damaged molecules along the track of the beta particle. The higher ionization density associated with lower energy beta particies enhances the effects of quenching, lowering the scintillation efficiency.

\subsubsection{Germanium Spectrometer}

In some cases, a portable, high-purity germanium detector was used to obtain photon spectra. In mixed fields, these were useful in interpreting beta spectra. The photon spectrometer system used a hyperpure germanium crystal. The remainder of the system is the same as described for the silicon detector. 
Raw data were in the form of pulse-height distributions. The detector signal was proportional to the photon energy only when the full energy was collected. The detector did not collect the full energy for most photons because of the high probability for scattered photons to escape. The pulseheight distributions were corrected for detector efficiency and scattering loss to yield energy spectra.

\subsubsection{Multielement Beta Dosimeter}

The multielement dosimeter developed at PNL (Scherpelz, Endres, and Rathbun 1983) uses thermoluminescent dosimeter (TLD) chips placed under aluminum filters of varying thicknesses. Each filter attenuates the beta radiation corresponding to the thickness of the filter. An indication of the beta-energy spectrum is obtained by comparing the relative responses of the TLDs under the different filters (elements) to those for dosimeters that have been exposed to calibrated sources. The relative responses allow for the selection of a calibration factor for converting TLD response to dose.

The multielement beta dosimeter used in this study has eight elements. Each element contains three TLD chips covered by a filter made of either Mylar or aluminum. Table 1 describes the filter materials and thicknesses used in the dosimeter. Figure 4 is a photograph of the eight-element dosimeter.

TABLE 1. Multielement Dosimeter Filter Specifications

\begin{tabular}{|c|c|c|c|}
\hline Filter Material & in. & $\mathrm{mm}$ & $\mathrm{mg} / \mathrm{cm}^{2}$ \\
\hline Aluminized Mylar & 0.00025 & 0.0063 & 0.65 \\
\hline Aluminum & 0.001 & 0.025 & 7 \\
\hline Aluminum & 0.005 & 0.127 & 34 \\
\hline Aluminum & 0.010 & 0.254 & 69 \\
\hline Aluminum & 0.020 & 0.508 & 137 \\
\hline Aluminum & 0.032 & 0.813 & 219 \\
\hline Aluminum & 0.064 & 1.626 & 439 \\
\hline Aluminum & 0.125 & 3.175 & 857 \\
\hline
\end{tabular}




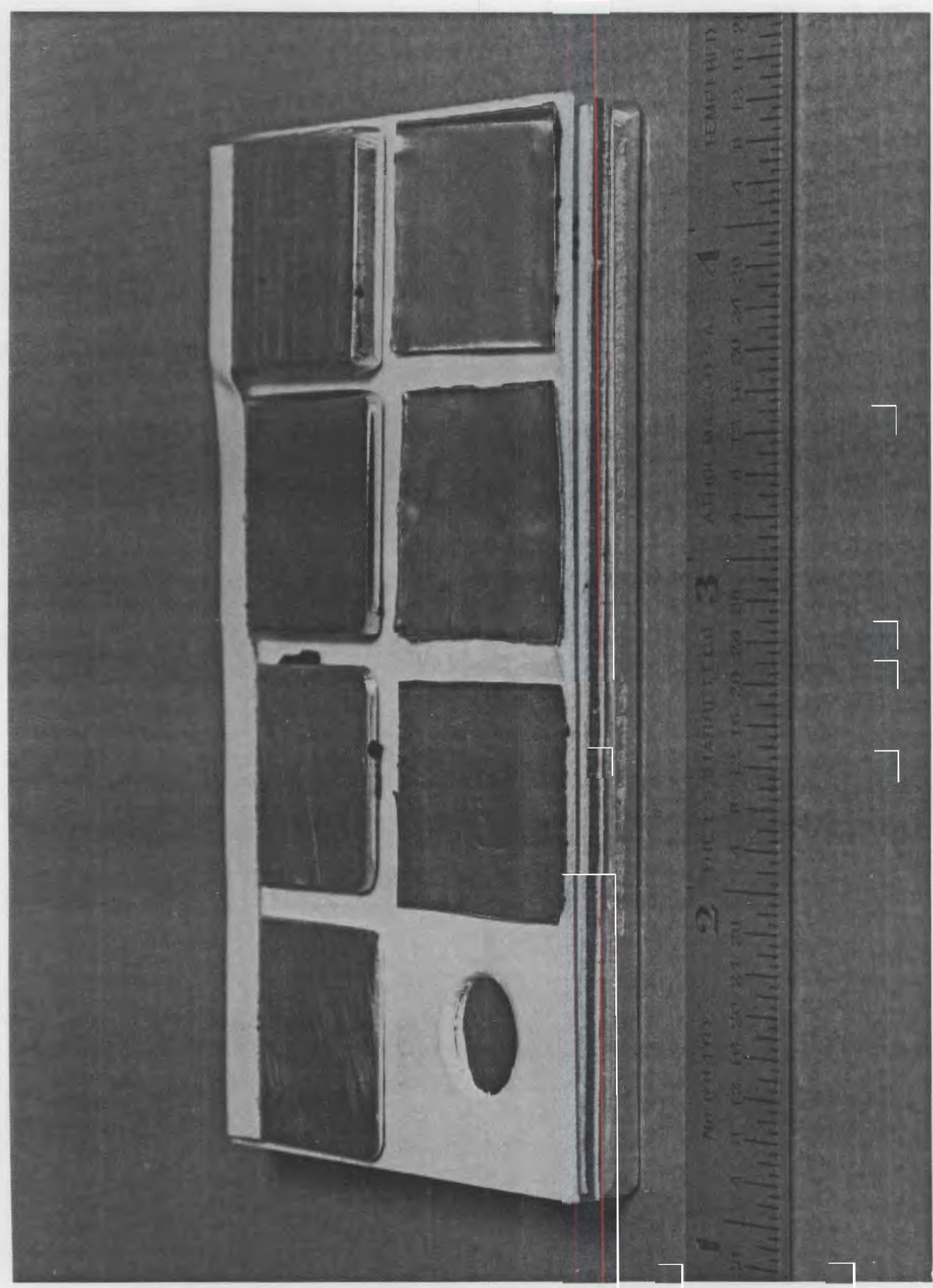

FIGURE 4. Eight-Element Dosimeter 
The dosimeters used were actually double-sided: two eight-element dosimeters were placed back-to-back, separated by a 3.175-mm aluminum sheet. Because the aluminum separator prevents beta particles that strike one face of the dosimeter from entering the other side, this dosimeter package can be used to measure the beta radiation coming from opposite directions. Thus, a dosimeter placed against a wall could determine separate doses for beta particles coming from wall contamination and for beta particles emitted by sources in the room.

The thickest dosimeter filter $(3.175 \mathrm{~mm})$ will stop beta particles with an incident energy of $1.9 \mathrm{MeV}$ or less. The $0.127-\mathrm{mm}$ filter will stop beta particles with energies below $180 \mathrm{keV}$. The Mylar filter will stop beta particles with energies below $20 \mathrm{keV}$. Photons with energies above $40 \mathrm{keV}$ are not significantly attenuated by any of the filters.

Throughout this report the dose and dose rates determined with the multielement dosimeters are considered to be true or reference quantities. The multielement dosimeter was used as a reference because it is well characterized and has an energy-dependent calibration for beta measurements. Detailed descriptions and examples of uses of the muttielement dosimeter can be found in several references (Scherpelz, Endres, and Roberson, 1984; Scherpelz, Endres, and Rathbun 1983; Rathbun et a1. 1984). The error of the photon measurements made with the dosimeters will be about $9.5 \%$. The error considers the standard deviations of the readings and of the calibration factors. For beta measurements, the errors will be about $11 \%$ for high beta-to-gamma ratios and will increase as the beta-to-gamma ratio decreases. The accuracy of the beta readings can be influenced by several factors:

- Nonuniform irradiation of the dosimeter elements by a gradient in the radiation field results in erroneous readings (the analysis routine flags these readings with a large error component).

- Significant exposures to low-energy photons ( $<40 \mathrm{keV})$ are recorded as beta exposures. 
- Low beta-to-photon ratios may result in large errors for beta readings because the photon reading is subtracted from the beta reading.

\subsubsection{Other Measurement Devices}

In addition to the measurement tools described above, survey meters and commercial-type and prototype thin dosimeters were also used in field measurements. This provided an opportunity to evaluate the performance of typical survey meters or dosimeters and to test development dosimeters. In most cases, the survey meters used belonged to the facility where measurements were being made. A few commercial survey meters available at PNL were also included. Two-element dosimeters, prepared at PNL to simulate commercial dosimeters, were used at nearly all sites where measurements were made. A commercially available two-element dosimeter was used at some sites and a commercially available four-element dosimeter was used at other sites. In most cases, the PNL dosimeters contained the conventional $235 \mathrm{mg} / \mathrm{cm}^{2} 1$ ithium fluoride TLDs. However, a few $100 \mathrm{mg} / \mathrm{cm}^{2}$ lithium fluoride TLDs and $17 \mathrm{mg} / \mathrm{cm}^{2}$ graphite-backed lithium fluoride TLDs were used. The latter were developmental dosimeters provided by Kansas State University (KSU) under a subcontract with PNL.

\subsection{DATA COLLECTION}

At each facility, PNL scientists reviewed routine survey data and discussed possible beta exposure sources with onsite health physics personnel. This information was used in conjunction with known equipment capabilities and potential for personnel exposure to choose the specific beta measurement locations.

To prevent contamination, all measuring devices were wrapped in plastic prior to entering radiation zones. The plastic covering acted as an additional filter for beta radiation, except for a few cases when it was removed at the measurement location. However, the plastic was less than $7-\mathrm{mg} / \mathrm{cm}^{2}$ thick in all cases. Thus, the projected skin dose was not affected. 
Field spectra were obtained under two distinct conditions. In the first case, silicon and scintillator spectrometer systems were set up in laboratory fume hoods. Small liquid sample vials and other contaminated materials were brought to the detector and placed immediately below the detector (Figure 5). The beta spectrum was obtained by subtracting the photon contribution (Figure 6) to the spectrum from the beta-plus-gamma spectrum (Figure 7 ). The photon contribution to the spectrum was determined by placing beta shieids of plastic, ranging from $7-\mathrm{mg} / \mathrm{cm}^{2}$ to $1000-\mathrm{mg} / \mathrm{cm}^{2}$ thick (ICRP 1977), over the detectors. The detectors were exposed to beta radiation from the sample 0.4 to $1 \mathrm{~cm}$ in front of the detector. In some laboratories the ambient photon radiation was low, with the major photon dose resulting from the sample. This led to high beta-to-gamma ratios and made the beta spectra easier to analyze. However, it may not be representative of the relative beta versus gamma dose to the worker.

In the second case, beta spectrometers were taken into actual production and maintenance areas at the facility. Some facilities had large quantities of unshielded uranium in various forms. This made the ambient beta-to-gamma ratios high. However, where fission products were found, or where the uranium was shielded in the work locations, low beta-to-gamma ratios resulted. This made the beta spectra difficult to interpret. 


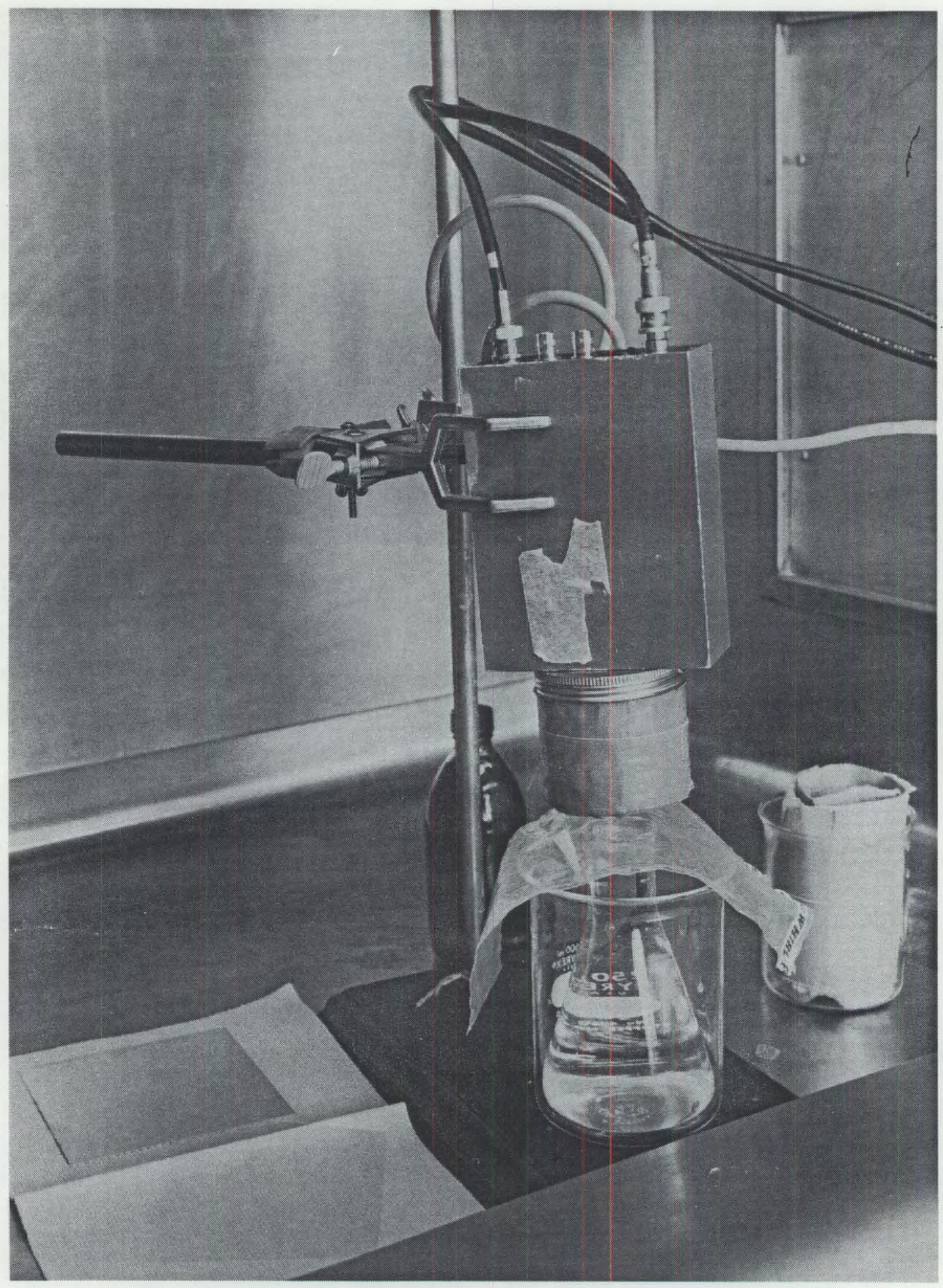

FIGURE 5. Surface Barrier Detector and Liquid Sample 


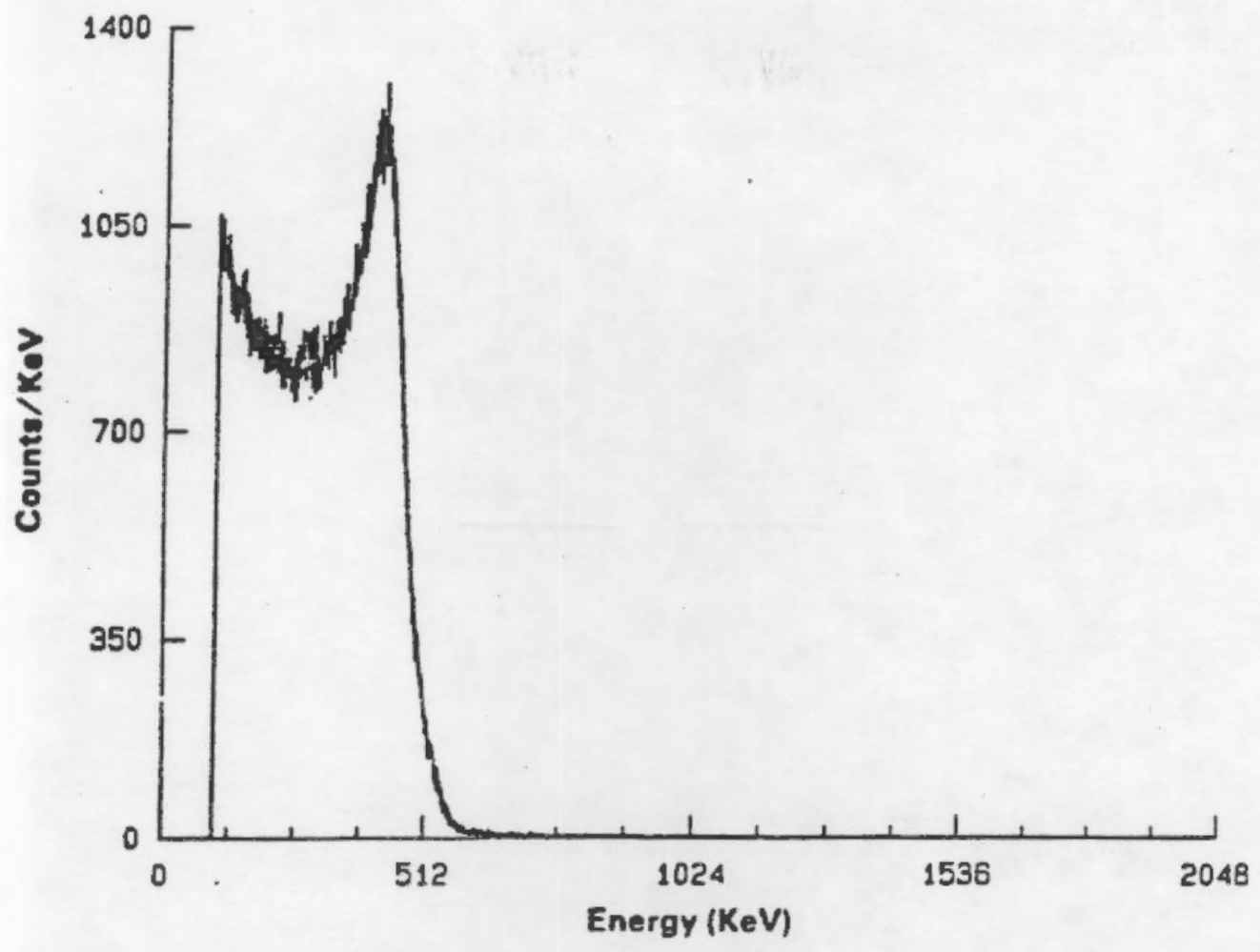

FIGURE 6. Cesium-137 Gamma Spectrum

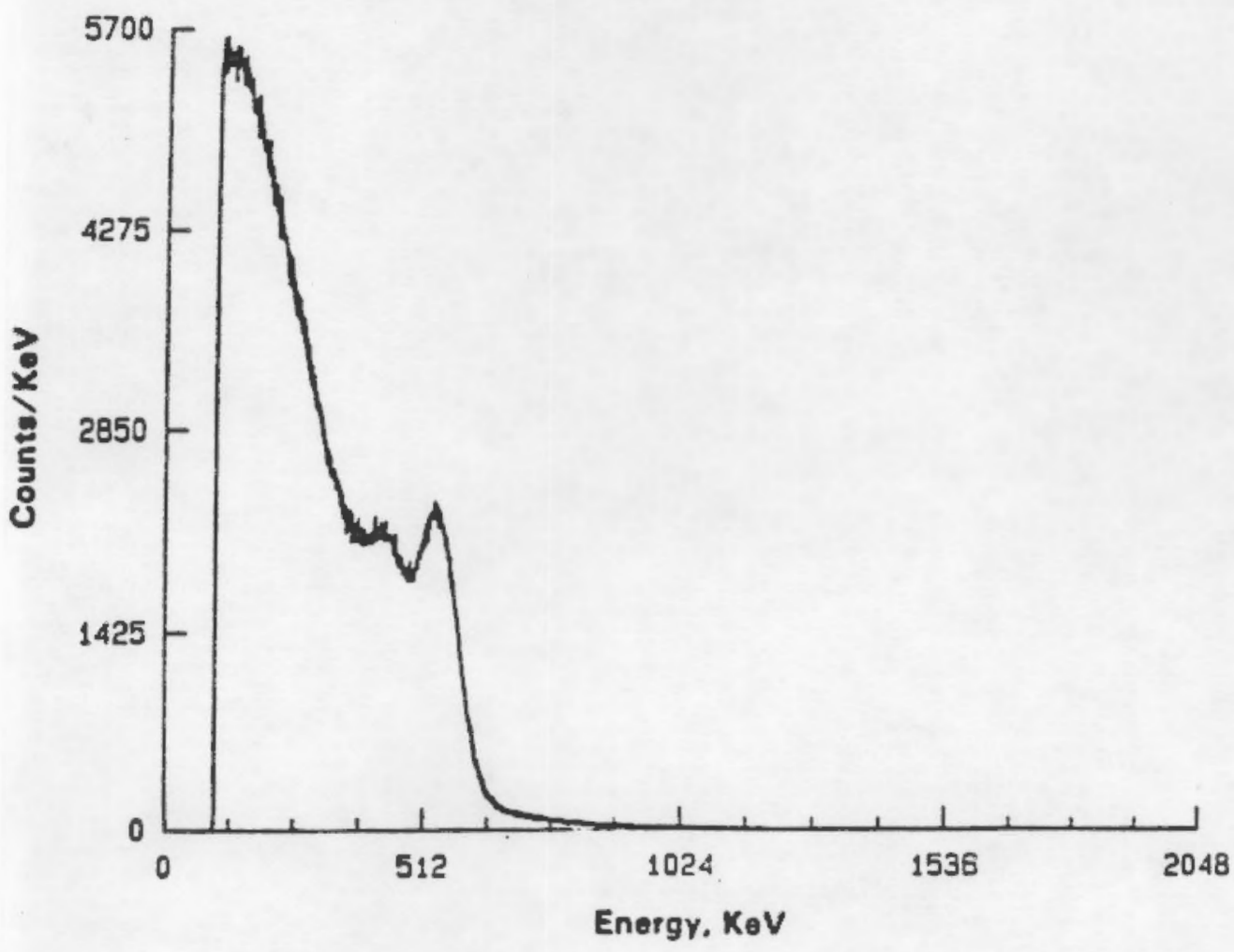

FIGURE 7. Cesium-137 Beta-Plus-Gamma Spectrum 



\subsection{ANALYSIS TECHNIQUES}

\subsection{SILICON AND PLASTIC SCINTILLATOR DETECTORS}

The following five sections describe how the data from the silicon and plastic scintillator detectors were analyzed. Beta detection and response, response to photons, average beta energies, beta dose calculations, and calibration are discussed.

\subsubsection{Beta Detection and Response}

Silicon detectors act as a solid-state analog of the ion chamber. Their structure is basically the same as that of normal semiconductor diodes for electronic applications, with a $p$-type region and an $n$-type region separated by a junction or depletion layer. The depletion layer is the sensitive part of the detector, where the concentration of charge carriers is practically zero. The detector is biased in the reverse direction. When a charged particle penetrates the depleted region, the electrons liberated there will move to the n-type zone (which has been given a positive voltage), while the positive charge carriers ("holes") move to the p-type zone. The average energy ( $\varepsilon$ ) necessary to create an electron-hole pair in a given semiconductor is independent of the type and the energy of the ionizing radiation. Therefore, the number of electron-hole pairs produced is proportional to the incident energy of the incident particle, provided the particle is fully stopped with in the active volume of the detector. The value of $\varepsilon$ for silicon at room temperature is $3.62 \mathrm{eV}$, compared to about $33 \mathrm{eV}$ needed to create an ion pair in a typical gas-filled detector.

When a beta particle interacts with a plastic scintillator, other electrons are set in motion. As these electrons travel through the crystal, they excite and ionize the atoms of the crystal and produce many flashes of light. The photons, which originate in the track, are emitted in all directions. The photons that reach the outside surface of the crystal are mostly returned by surface reflection and by reflection from the covering. As long as they are not absorbed in this covering, they will eventually pass through the light guide and strike the photosensitive surface of the photomultiplier. Upon striking the photosensitive surface, the light photons then eject low-energy 
photoelectrons, which are collected and amplified. The number of electrons ejected from the photosensitive surface will be proportional to the amount of light that reaches this surface. This amount of light is in turn proportional to the energy absorbed from the beta particles incident on the crystal.

For both the silicon and plastic scintillator detectors, the output pulse of electrons is proportional to the initial energy of the incident beta particle. After amplification, the output pulses are fed into a pulse-height analyzer, which sorts them into equal energy intervals. If the detector systems are calibrated to the endpoint of a beta spectrum of known maximum energy, the pulse-height spectrum can be interpreted in terms of energy. Corrections are still necessary for backscatter and the portion of the spectrum lost due to the discriminator setting of the analyzer.

For the thicknesses stated (in Section 2.0), both detector systems have good detection efficiencies for beta particles between $125 \mathrm{keV}$ and approximately 2.5 MeV. Below 125-keV, backscatter of beta particles from the surface of the detectors (especially silicon) causes a much lower detection efficiency. The response of the detectors is also nonlinear with respect to energy in this region due to a rapidly changing stopping power. In addition, electronic noise and $x$-ray interference normally prevent the analysis of beta particle interactions in the silicon detector below $70 \mathrm{keV}$ and in the plastic scintillator below $40 \mathrm{keV}$. Considerably better results for low-energy particles are possible under optimum laboratory conditions. However, for radiation protection purposes, it is not necessary to analyze beta particles below $70 \mathrm{keV}$.

Based on the discussion above, the plastic scintillator is a better choice for beta particle measurements in low-intensity fields. The scintillator has lower backscatter, responds to lower energies, and is nearly equivalent to tissue in its radiation absorption characteristics. However, the upper limit for this detector is approximately $100 \mathrm{mrad} / \mathrm{h}$. The silicon detector can be used up to approximately $1 \mathrm{rad} / \mathrm{h}$. Beyond these limits, pulse pileup becomes a problem.

Figure 8 illustrates the response of the silicon detector to three laboratory beta sources. These spectra exhibit significant departures from the bell-shaped curve typically thought to be characteristic of beta spectra. 


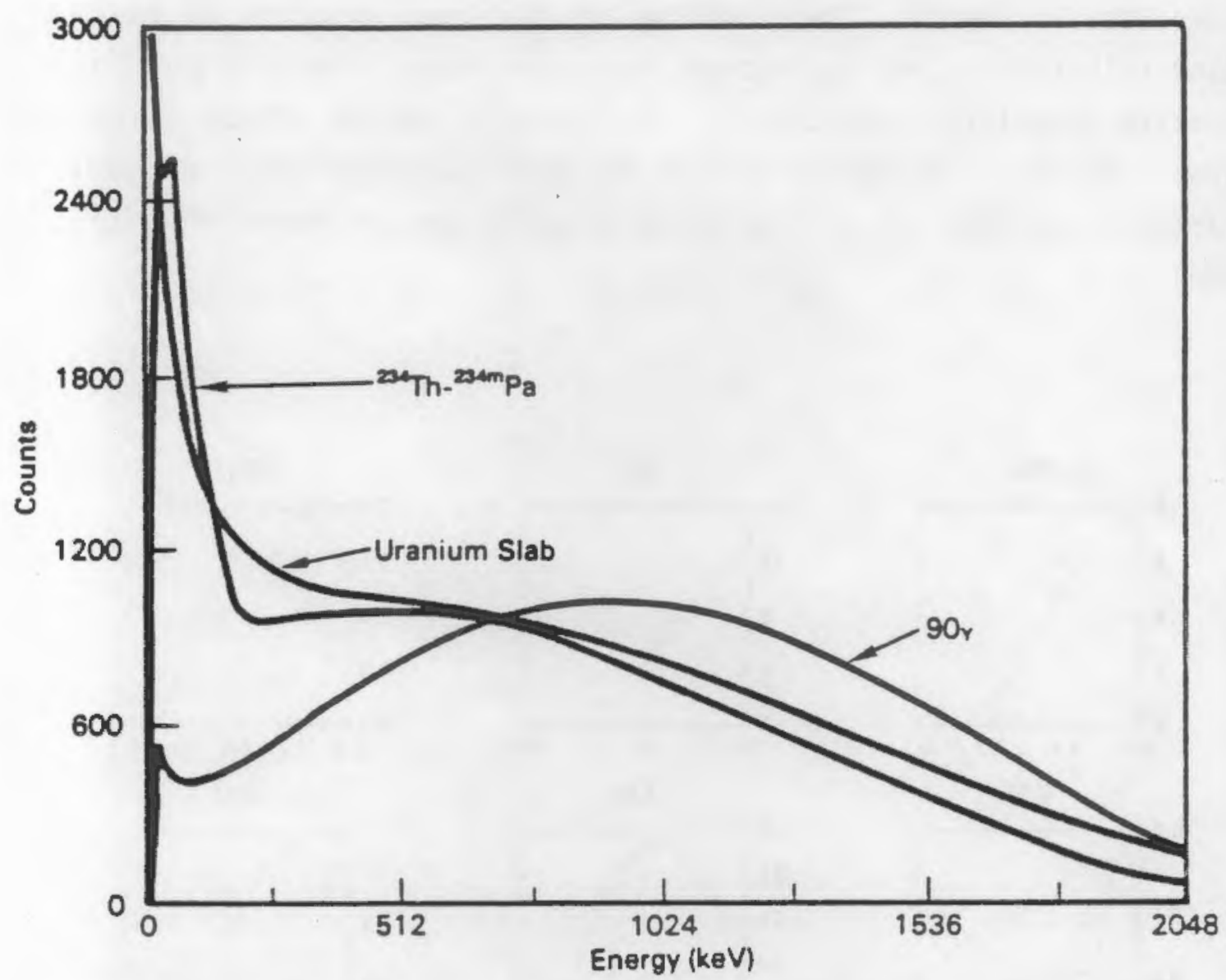

FIGURE 8. Comparative Detector Responses to Laboratory Beta Sources

The bell shape arises from probability considerations about the electron and neutrino sharing the available nuclear disintegration energy. When a nucleus disintegrates by beta-ray emission, the most probable division of energy between the beta particle and neutrino is that each will carry roughly the same energy. Departures from the bell shape (such as those seen above) depend on whether more than one endpoint energy is involved $\left({ }^{90} \mathrm{Sr} /{ }^{90} \mathrm{Y}\right)$ and whether the beta particles leave the nucleus tangentially or radially.

In a pure beta field emanating from a single beta emitter, or even two beta emitters if their spectra have widely differing maximum energies, it is possible simply by observation to identify the nuclides responsible for the beta field. This is important because it helps to determine endpoint and average energy and calculate doses. To aid in identifying nuclides, theoretical spectra can be generated based on the quantum mechanical theory of beta 
decay developed by Fermi. These spectra are made more accurate by the application of relativistic and self-screening corrections. Figure 9 shows typical beta spectra calculated from theory. In Figure 9, the horizontal scales give energies in million-electron volts and the vertical scales give the number of beta particles emitted per million-electron volts for one transition (Cross et a). 1984).
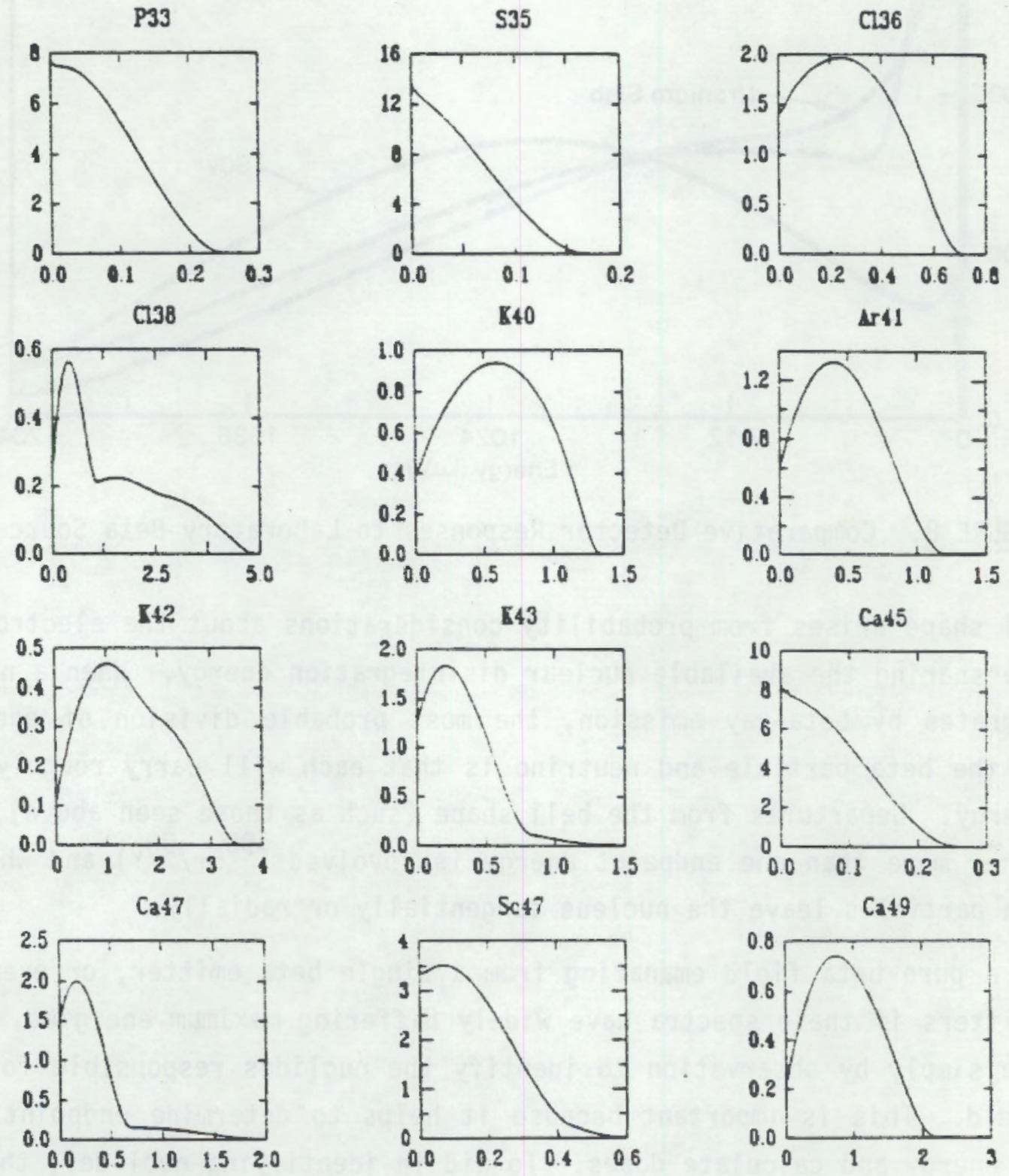

FIGURE 9. Examples of Beta-Ray Spectra, Illustrating the Wide Variety of Shapes 


\subsubsection{Photon Response}

For typical nonlaboratory conditions, radiation fields are seldom caused by pure beta emitters. Therefore, the response of the detectors to photons is important. Although photon contributions to the spectrum can ideally be subtracted out, a one-to-one subtraction often does not completely remove the photon-generated portion, especially in high photon flux measurements. Virtually all the photon interactions of importance in the detectors are Compton scattering events, with recognizable Compton edges. Compton scattering is an elastic collision between a photon and a free electron. The Compton electron dissipates its kinetic energy in the same manner as a beta particle in the silicon detector. The compton electron can have any energy up to a maximum value, which approaches (but never equals) the energy of the incident photon. An "edge" or sudden decrease in pulse height occurs in the spectrum at these maximum electron energies. Compton edges are useful in identifying nuclides and calibrating the detector system (Attix and Roesch 1968).

\subsubsection{Average Beta Energies}

One property of a beta-ray spectrum that is of great importance in dosimetry is the average beta-ray energy per disintegration $\left(E_{B}\right)$, which is defined as

$$
E_{B}=\frac{\int_{0}^{E_{0}} E N(E) d E}{\int_{0}^{E_{0}} N(E) d E} \mathrm{MeV} / \mathrm{dis}
$$

where $N(E)$ is the relative number of beta particles in the spectrum with energy between $E$ and $E+d E$, per unit energy interval and $E$ is the beta energy. The importance of $E_{\beta}$ is that it represents, on the average, the beta-ray energy per disintegration that can be absorbed by tissue from radioactive decay within the tissue. The average beta energy is approximately one third of the maximum beta energy.

It follows from Equation (1) that $E_{B}$ can be computed by graphical integration of a beta spectrum. 


\subsubsection{Dose Calculations}

Figure 10 shows the silicon detector, whose detection volume is the depletion region around the junction. It can be seen that the average dose absorbed in this region is

$$
\frac{\sum_{E}}{m}
$$

where $\sum_{E}$ is the energy lost by beta particles while travelling in the depletion region with mass, $m$.

Dose can be measured by relatively simple pulse-height analysis of the charge pulses observed.

The beta dose calculation is based on the concept that the mass stopping power for a particular energy beta particle multiplied by the fluence of beta particles with that energy is equivalent to the dose-rate contribution from particles of that energy. The energy spectrum is actually a histogram of energy versus frequency, so the fluence in each energy bracket is multiplied by the median mass stopping power for that energy bracket. The median mass

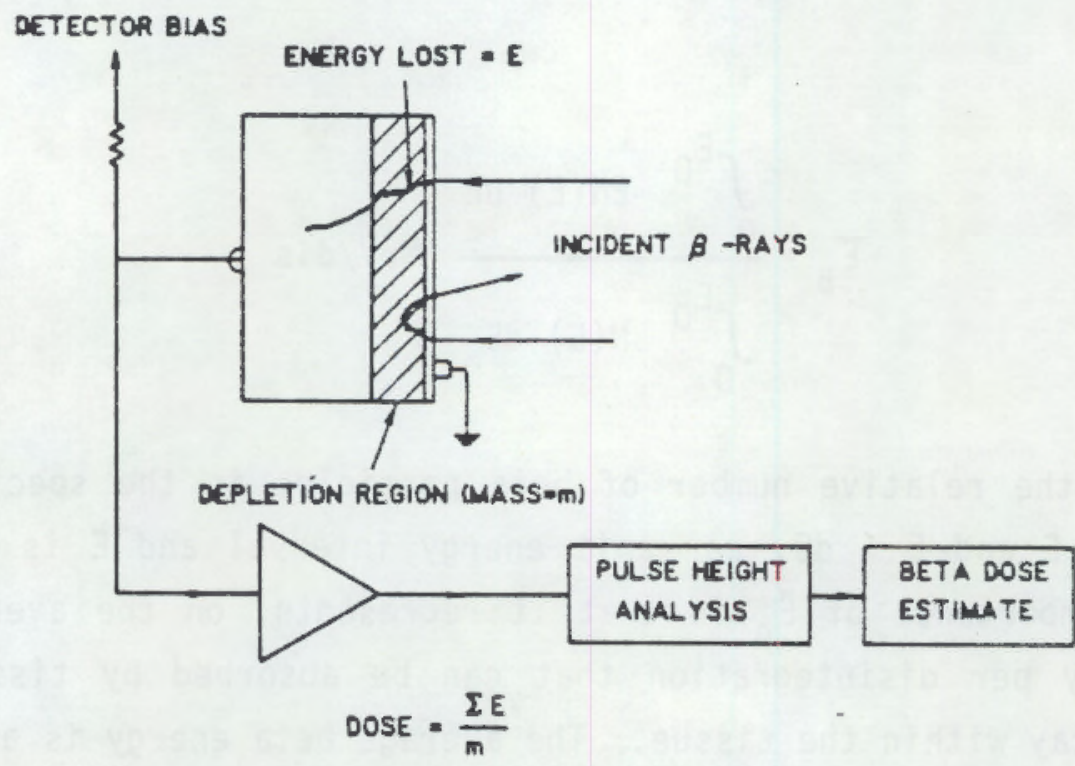

FIGURE 10. Reversed Biassed Silicon Junction Beta Dosimeter (Jones 1984) 
stopping power is determined using Bethe's continuous slowing down approximation. The integral value of this multiplication is equal to the absorbed dose per unit time. However, this product must be multiplied by $1.6 \times 10^{-6} \mathrm{ergs} / \mathrm{MeV}$ to give standard dosimetric units (Murphy et al. 1984). Also, because of the nonlinear response for low-energy beta particles, an empirical correction factor of 1.33 must be applied.

\subsubsection{Calibration}

In order to perform accurate measurements, calibrations must be performed for energy response and efficiency. Energy calibration and efficiency calibration are discussed in the following sections.

\section{Energy Calibration}

Because of the easily recognizable conversion electron peak and the welldefined Compton edges, ${ }^{137} \mathrm{Cs}$ and ${ }^{207} \mathrm{Bi}$ are the radionuclides of choice for the calibration of silicon detectors and plastic scintillators.

Internal conversion involves the emission of an electron in the de-excitation of a nucleus by direct coupling between the excited nucleus and an extranuclear electron, usualiy one in the $\mathrm{K}, \mathrm{L}$, or $M$ shell. The ejected electron, called a conversion electron, has kinetic energy equal to the difference between the transition energy and the binding energy of that electron. Conversion electrons are observed as a line spectrum easily distinguishable from the continuous beta-ray spectrum when beta rays are present.

An International Atomic Energy Agency (IAEA) ${ }^{137}$ Cs source with very thin encapsulation was used as the primary source of calibration. This source is traceable to the National Bureau of Standards. Both detectors discussed in Section 3.1 can also be calibrated to the endpoint energies of sources such as

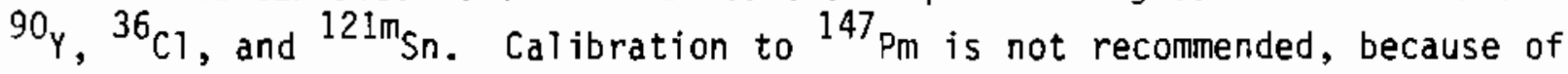
the low-energy nonlinearity of the detectors.

Efficiency Calibration

In order to make accurate measurements of doses and dose rates the efficiency of the detectors and dosimeters must be known for the conditions in which they are used. The efficiency calibration is affected by the beta 
energy, the source geometry, and the source to probe distance. Energy calibration factors were determined by using the sources recommended by the International Organization of Standardization (ISO 1981) and sources of ${ }^{85} \mathrm{Kr}$, nat ${ }$, and ${ }^{106} \mathrm{Ru} /{ }^{106} \mathrm{Rh}$, which are calibrated and maintained at the PNL calibrations Taboratory.

Beta doses and dose rates are often measured near sources of various geometries. This requires corrections to the instrument response because efficiency calibrations generally assume a uniform irradiation of the detector volume. Such correction factors vary with energy and instrument in addition to the geometrical variables. Complete data for such corrections are not available, and data determined for a few instruments in use at PNL were used as appropriate. The calibrations are discussed in more detail in the following sections, which discuss the specific measurement tools.

\subsection{PACIFIC NORTHWEST LABORATORY MULTIELEMENT DOSIMETER}

The analysis of multielement dosimeter measurements is described below in Sections 3.2.1, TL Chip Readout and Dose, and 3.2.2, Calibration.

\subsubsection{Thermoluminescent Chip Readout and Dose}

Thermoluminescent chips taken from the dosimeters are read out in a TLD reader which provides results in units of nanocoulombs per unit of iight output. The TLD responses are then used as raw data in a computer program that converts the TLD responses to absorbed doses.

The reading for the TLDs under the thickest filter $(3.175 \mathrm{~mm})$ is used to indicate the gamma dose, and this value is subtracted from the other element readings to obtain the response due to beta particles alone. The program then determines the response ratios of aluminum-covered elements to the Mylarcovered element. It uses these ratios, which are an indication of the betaenergy spectrum, to select the appropriate beta-energy correction factor. This correction factor is then multiplied by the response of the Mylar-covered element to determine the beta dose at $0.65 \mathrm{mg} / \mathrm{cm}^{2}$. 


\subsubsection{Calibration}

The multielement beta dosimeters were calibrated by exposing them to known radiation sources at the PNL calibrations laboratory. The beta sources used in these calibrations and the maximum energies of the emitted beta particles are presented in Table 2.

The dosimeters were also exposed to calibrated sources of $x$ rays with effective energies ranging from 15 to $78 \mathrm{keV}$, and to a calibrated ${ }^{137} \mathrm{Cs}$ source emitting $662-\mathrm{keV}$ gamma rays. These measurements characterized the multielement dosimeter response to photons and showed that photon attenuation is measurable only for energies less than about $40 \mathrm{keV}$. For photons with higher energies, the TLD response is fairly uniform for all elements. This dosimeter characteristic permits using the response of the element with the thickest aluminum filter as an indicator of photon dose.

The data from these beta and photon calibrations were used to derive calibration factors for determining the beta doses from exposed dosimeters (Scherpelz, Endres, and Rathbun 1983).

For each dosimeter exposed to a calibrated beta source, a beta "Calibration Factor" was determined by subtracting the gamma component (the reading of the element covered by the $0.318-\mathrm{cm} \mathrm{Al}$ shield) from the TLD response of the Mylar-covered shield, and dividing this value (in nanocoulombs) into the beta dose (in rads) absorbed by the Mylar-covered TLDs during the calibration measurement. The beta dose delivered by the calibration source is defined as the dose to tissue at a depth of $7 \mathrm{mg} / \mathrm{cm}^{2}$. This factor could then be used to

IABLE 2. Characteristics of Beta Calibration Sources

$\begin{array}{ccccc}\text { Nuclide } & \begin{array}{c}\text { Maximum Beta, } \\ \text { Energy, MeV }\end{array} & & \begin{array}{c}\text { Dose Rate, } \\ \text { mrad/h }\end{array} & \begin{array}{c}\text { Distance, } \\ \mathrm{cm}\end{array} \\ { }^{147} \mathrm{Pm} & 0.23 & & 10.2 & 20 \\ { }^{85} \mathrm{Kr} & 0.62 & & 1150 & 50 \\ { }^{204} \mathrm{Tl} & 0.76 & & 64.1 & 30 \\ { }^{90} \mathrm{Sr} /{ }^{90} \mathrm{Y} & 2.3 & & 164 & 50 \\ { }^{106} \mathrm{Ru} /{ }^{106} \mathrm{Rh} & 3.5 & & 200 & 50\end{array}$


convert the responses of other dosimeters to a $7-\mathrm{mg} / \mathrm{cm}^{2}$ dose, as 1 ong as the dosimeters were exposed to a field of beta particles with the same energy distribution as the beta caljbration source. For each of the five elements with aluminum shields between $0.013-$ and $0.163-\mathrm{cm}$ thick, the ratio of the element's beta response to the Mylar-covered element's beta response was found for each calibration measurement. This ratio was a function of the calibration source's energy distribution: high beta energies resulted in high values of these ratios.

\subsection{COMMERCIAL DOSIMETERS AND OTHER DOSIMETERS}

Commercial dosimeters and other dosimeters similar to those used at various DOE facilities were placed at many of the locations where spectral and survey meter measurements were obtained. Both two- and four-element dosimeters were exposed during field measurements. Thermoluminescent (TL) materials in the dosimeters included lithium floride, lithium borate, and calcium sulphate. The TL materials ranged in thickness from approximately $17 \mathrm{mg} / \mathrm{cm}^{2}$ to $240 \mathrm{mg} / \mathrm{cm}^{2}$. Filters covering the $\mathrm{TL}$ materials ranged from $0.006-\mathrm{mm}$ $\left(0.65-\mathrm{mg} / \mathrm{cm}^{2}\right)$ aluminized Mylar to $0.102 \mathrm{~cm}$ of tin and $0.08 \mathrm{~cm}$ of plastic. This tin-plastic filtration is equal to a mass thickness of $900 \mathrm{mg} / \mathrm{cm}^{2}$.

In a two-element dosimeter, the dose is determined from the following expression

$$
\text { Calibration Exposure } x \frac{\left(R_{1}-K_{2} R_{2}\right) \text { Field Exposure Chip Readings }}{\left(R_{1}-K_{2} R_{2}\right) \text { Calibration Exposure Chip Readings }}
$$

where $R_{1}$ and $R_{2}$ are the net readings of chips 1 and 2 after subtracting their respective chip backgrounds, and $k_{2}$ is a constant nearly equal to 1.0 representing the differences in ${ }^{137} \mathrm{Cs}$ photon response between $R_{1}$ and $R_{2}$. The penetrating dose calculation is most direct, depending only on the net response of chip 2 relative to the calibration response. The evaluation of four-element dosimeters follows the procedure indicated for the PNL multielement dosimeter (Scherpelz, Endres, and Rathbun 1983). 
Both the two-element dosimeters designed at PNL and the commercial two-element dosimeters consisted of a set of TLDs under a thin absorber $\left(88 \mathrm{mg} / \mathrm{cm}^{2}\right.$ for PNL and $30 \mathrm{mg} / \mathrm{cm}^{2}$ for commercial) and a set of TLDs under a thick absorber, approximately $350 \mathrm{mg} / \mathrm{cm}^{2}$ in both cases. The PNL two-element dosimeters were calibrated to ${ }^{137} \mathrm{CS}$ ganma rays and ${ }^{90} \mathrm{Y}$ beta particles.

The calibration factors for the various TLDs in the PNL-design and commercial two-element dosimeters are shown in Table 3 . The commercial dosimeters were calibrated and processed by the supplier.

Because the trend is to calibrate dosimeters with high-energy beta sources, i.e., ${ }^{90} \mathrm{Sr} /{ }^{90} \mathrm{Y}$ with a $100-\mathrm{mg} / \mathrm{cm}^{2}$ attenuator, nonconservative beta dose results are often obtained. Causes for this situation are twofold: the covering material is too thick and the dosimeters are too thick. The covering material can easily be made thinner. However, the effect of a thin covering is Targely lost when the TLD behind the thin window is covered by a security badge. Thin TLDs were used by KSU to obtain experimental verification of the strong energy dependence of TLDs exposed to beta radiation. Table 4 presents a brief summary of how much the doses would be underestimated for different maximum energy beta sources, relative to the ${ }^{90} \mathrm{Sr} /{ }^{90} \mathrm{Y}$ dose measured at $50 \mathrm{~cm}$ in air. For a commercial $0.89-\mathrm{mm}-\left(235 \mathrm{mg} / \mathrm{cm}^{2}-\right)$ thick TLD covered with $1.45 \mathrm{mg} / \mathrm{cm}^{2}$ of Mylar, the reported dose would be high by $290 \%$ for ${ }^{204} \mathrm{Tl}$ beta

\section{TABLE 3. Calibration Factors for Two-Element Dosimeters}

\begin{tabular}{|c|c|c|}
\hline $\begin{array}{c}\text { TLD Thickness, } \\
\mathrm{mg} / \mathrm{cm}^{2}\end{array}$ & $\begin{array}{c}\text { Gamma } \\
\text { Calibration Factor, } \\
\mathrm{rad} / \mathrm{nC} \\
\end{array}$ & $\begin{array}{c}\text { Beta } \\
\text { Calibration Factor, } \\
\mathrm{rad} / \mathrm{nC} \\
\end{array}$ \\
\hline 235 & 1.89 & 2.67 \\
\hline 100 & 4.59 & 5.70 \\
\hline $17^{(a)}$ & 28.2 & 33.9 \\
\hline
\end{tabular}

(a) The calibration factors for the $17 \mathrm{mg} / \mathrm{cm}^{2}$ TLDs apply onily to the average of the group. Each TLD in the group had an additional correction factor to compensate for variations in thickness. This additional factor was usually between 0.9 and 1.1 . 
TABLE 4. Measured Factor for How Much a LiF TLD Would Underestimate the Actual Beta Dose Relative to the PTB ${ }^{90} \mathrm{Sr} /{ }^{90} \mathrm{Y}\left(\mathrm{E}_{\max }=2.27 \mathrm{MeV}\right)$ Dose

\begin{tabular}{|c|c|c|c|c|c|c|c|}
\hline \multirow[b]{2}{*}{$\begin{array}{l}\text { Beta } \\
\text { Source }\end{array}$} & \multirow{2}{*}{$\begin{array}{c}\text { Maximum } \\
\text { Beta Energy, } \\
\text { MeV }\end{array}$} & \multirow{2}{*}{$\begin{array}{c}\text { Cover } \\
\text { Thickness, } \\
\mathrm{mg} / \mathrm{cm}^{2} \\
\end{array}$} & \multicolumn{5}{|c|}{ Average TLD Thickness, $\mathrm{mg} / \mathrm{cm}^{2}$} \\
\hline & & & $\begin{array}{c}235 \\
(\mathrm{LiF}) \\
\end{array}$ & $\begin{array}{c}18.9 \pm 5.3 \\
\text { (L.iF) }\end{array}$ & $\begin{array}{c}13.1 \pm 4.2 \\
(\mathrm{LiF}) \\
\end{array}$ & $\begin{array}{c}19.3 \pm 2.8 \\
\left({ }^{7} \mathrm{LiF}\right) \\
\end{array}$ & $\begin{array}{c}24.7 \pm 7.8 \\
\left({ }^{6} \mathrm{LiF}\right) \\
\end{array}$ \\
\hline${ }^{147} \mathrm{Prn}$ & $0.225^{(a, b)}$ & 0 & - & 2.91 & 2.24 & 2.80 & 3.44 \\
\hline & & 1.4 & 27.4 & 4.27 & 3.31 & 3.89 & 4.89 \\
\hline
\end{tabular}

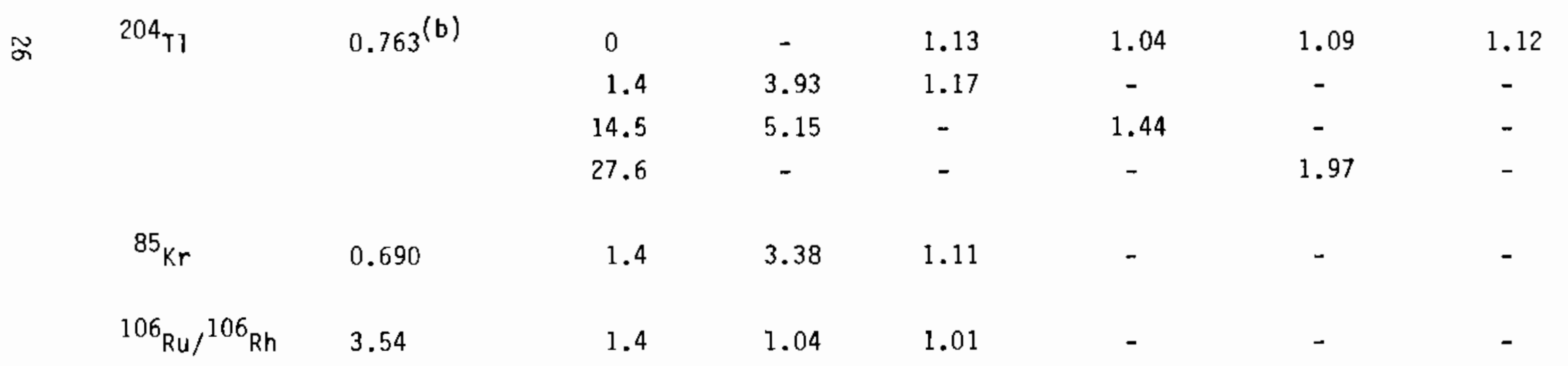

(a) The maximum beta energy was much less than this value at the TLD position.

(b) Physikalish-Technische Budesanstalt (PTB) sources. 
particles. The corresponding error for a nominat $18.9 \mathrm{mg} / \mathrm{cm}^{2}$ TLD would be $17 \%$. The ${ }^{147} \mathrm{Pm}$ data are difficult to discuss because $200 \mathrm{~mm}$ of air and a beam flattener were between the source and the TLDs. This configuration would provide extremely low-energy beta particles. Nevertheless, typical errors for thick and thin TLDs were factors of 27.4 and 4.27 , respectively.

\subsection{SURVEY METERS}

The survey meters found at each DOE facility visited were studied for performance under field conditions. All the survey meters (except two) were of the air ionization type. The survey meters tested are referenced by a randomly assigned alphabetical character to avoid comparison of specific products. The exceptions were a cylindrical GM tube (Instrument D) and a thin scintillator survey instrument (Instrument $E$ ). Detector window thickness ranged from $3.5 \mathrm{mg} / \mathrm{cm}^{2}$ to $30 \mathrm{mg} / \mathrm{cm}^{2}$. Alt instruments were designed to measure both beta and gamma radiation. In two cases, the instrument design favored photon monitoring over beta monitoring because the length of the detector exceeded the width of the detector. However, for one ion chamber the width (diameter) was about 1.7 times the length of the detector chamber. Even though this ratio is far from optimal, it tends to favor beta monitoring. The advantages of beta monitoring of a "pancake" type of ion chamber were described by Roesch and Donaldson (1956), but this type of instrument has not been commercially manufactured in the United States.

The response of a survey meter to beta fields is imperfect because it uses a large volume to represent the dose to a small volume of tissue. Beta fields will lead to energy-dependent response of meters because low-energy beta particles cannot uniformly irradiate the detector volume (Table 5). Similarly when the geometry of the source or the source-to-detector distances lead to nonuniform irradiation of the detector volume, the actual dose rate will be underestimated (see Tables 6 and 7, where Instrument $C$ is an ionchamber survey meter in a "Cutie Pie" configuration). In order to correctly estimate the dose rate, correction factors similar to those in Tables 5, 6, and 7 must be applied to the instrument readings. 
TABLE 5. Energy Calibration Factors for Survey Instruments (a)

\begin{tabular}{|c|c|c|c|c|c|c|}
\hline Source & ${ }^{147} 7_{\mathrm{Pm}}$ & ${ }^{85} \mathrm{Kr}$ & I 204 & ${ }^{90} \mathrm{Sr} /{ }^{90} \mathrm{Y}$ & $U_{\text {nat }}$ & ${ }^{106} \mathrm{Ru} /{ }^{106} \mathrm{Rh}$ \\
\hline Maximum Energy, MeV & 0.23 & 0.62 & 0.76 & 2.3 & 2.3 & 3.5 \\
\hline Distance, $\mathrm{cm}(\mathrm{a})$ & 20 & 50 & 30 & 50 & contact & 50 \\
\hline $\begin{array}{l}\left.\text { A (air ion, } 7 \mathrm{mg} / \mathrm{cm}^{2}\right) \\
208 \mathrm{cC}\end{array}$ & 2.8 & 2.6 & 2.5 & 1.2 & 3.2 & 1.8 \\
\hline $\begin{array}{l}D\left(\mathrm{GM}, 30 \mathrm{mg} / \mathrm{cm}^{2}\right) \\
17.3 \mathrm{cC}\end{array}$ & 1.8 & & & & 6.4 & \\
\hline $\begin{array}{l}E \text { (thin scintillator } \\
\text { dose rate meter) }\end{array}$ & 1.0 & 1.6 & 1.0 & 1.0 & & 0.8 \\
\hline
\end{tabular}

(a) Rathbun et at. (1984). TABLE 6. Examples of "Cutje)Pie" (Instrument C) Correction Factor
for Disk Sources

\begin{tabular}{|c|c|c|c|c|}
\hline \multirow{2}{*}{$\begin{array}{c}\text { Source } \\
\text { Diameter }\end{array}$} & \multirow{2}{*}{\multicolumn{4}{|c|}{ Source - Window Distance }} \\
\hline & & & & \\
\hline & & & & \\
\hline $1 / 2$ in. & 90.0 & 9.0 & 1.9 & 1.0 \\
\hline $1 \mathrm{in.}$ & 35.0 & 5.0 & 2.0 & 1.0 \\
\hline $6 \mathrm{in.}$ & 4.5 & 2.6 & 2.2 & 1.0 \\
\hline $1 \mathrm{ft}$ & 4.5 & 2.5 & 2.3 & 1.3 \\
\hline $6 \mathrm{ft}$ & 4.5 & 2.5 & 2.5 & 2.3 \\
\hline
\end{tabular}

(a) In order to obtain the beta exposure/dose rate at the detector window, multiply the meter reading by the applicable correction factor (from Selby et al. 1983).

A thin scintillator survey meter was developed by the Idaho National Engineering Laboratory (INEL) and described in a paper by Johnson et al. (1983). The detector system consists of a very thin plastic scintillator (NE-105) covered by a light-tight, aluminumized Mylar entrance window. The scintillator is backed by a $1-c m-t h i c k$, lucite, light pipe, attached to a photomultiplier tube. 
TABLE 7. Examples of "Cutie Pie" (Instrument C) Correqtion

Factors for Contact with Cylindrical Sources

\begin{tabular}{lr}
$\begin{array}{lr}\text { Cylinder } \\
\text { Diameter }\end{array}$ & $\begin{array}{r}\text { Correction } \\
\text { Factor }\end{array}$ \\
\cline { 3 - 3 } $1 / 2$ in. & 31.0 \\
$3 / 4$ in. & 17.0 \\
1 in. & 11.0 \\
2 in. & 5.7 \\
3 in. & 5.0
\end{tabular}

(a) Correction factors are for cylinders greater than $3-i n$. long (from Selby et a1. 1983).

For all the survey meters, except the dual chamber instrument and the thin scintillator device, discrimination between nonpenetrating and penetrating radiation was determined as follows:

- penetrating dose rate $=$ meter reading with filter covering the window

- nonpenetrating dose rate $=$ (meter reading with filter removed meter reading with filter in place) $x$ correction factor.

The dual-chamber survey meter measured beta-pius-gamma fields and gamma fields simultaneously. Correction factors were determined by placing the instruments on a uranium slab covered by $7-\mathrm{mg} / \mathrm{cm}^{2}$ filtration and by following the specified procedures for the ISO beta sources (ISO 1981). AIthough Instruments B and $F$ were not calibrated by PNL, typical calibration factors for similar instruments were previously determined by PNL and are listed in Tables 5, 6 , and 7. Instrument $B$ should have a calibration factor that is close to that of Instrument $A$, and Instrument $F$ had a calibration factor of 1 in the configuration used.

Typically, beta survey meters at DOE facilities are calibrated to either a uranium slab or a ${ }^{90} Y$ point source and the face of the instrument is usually the point of calibration. The calibration factors thus derived (3.2 and 1.2 
for uranium and ${ }^{90} Y$, for Instrument A) are applicable only when the instrument is exposed to field conditions that are similar to the calibration conditions. Because the instrument readings are commonly used to determine potential doses to individuals, the instrument must be in the same proximity to the source as the person might be. In some cases, the beta energies, geometry, and filtering media that occur in a personnel exposure situation adequately match the conditions under which the instrument was calibrated. For example, the calibration factor derived for a ${ }^{90} Y$ point source at $50 \mathrm{~cm}$ can be used for much larger sources at distances greater than $50 \mathrm{~cm}$. Also, due to a fortunate coincidence, the calibration factor for a survey meter with its face in contact with a uranium slab is often only slightly larger (Table 5) than the calibration factor for the same instrument with its face at $20 \mathrm{~cm}$ from a ${ }^{147} \mathrm{Pm}_{\mathrm{m}}$ point source. The average factor (Instrument A) for the uranium slab and $90 \mathrm{Y}$ source is

$$
\frac{(1.2+3.2)}{2}=2.2(\text { Table } 5)
$$

The highest calibration factor for the face of Instrument $c$ in Table 6 is 2.5. Based on the foregoing discussion, a calibration factor of 2.5 is considered conservative for all except contact and near-contact situations, and it is used by many DOE contractors for instruments simitar to $A$ and $C$. However, calibration factors ranging from 1 to 5 have been observed. As seen in Tables 6 and 7 , Targe correction factors are needed for survey meters when near-contact readings are desired. These factors vary with the type of instrument, the calibration parameters adopted, and the source geometry.

For many popular survey meters, if the calibration point is taken as the center of the instrument chamber rather than the face, the calibration factor will be between 1 and 2 for all conditions except very close to small or lowenergy sources. Using the center of the chamber volume as a reference makes it impossible to obtain dose rates within a few centimeters of the source. This information is often important because workers work close to the materiat. 


\subsection{RESULTS}

\subsection{FIELD SPECTRA MEASUREMENTS}

This section discusses the results of field measurement conducted at each of the seven DOE facilities (Sites $A$ through $G$ ).

\subsubsection{Site A: Separations Facility}

Field measurements were conducted at site $A$ on two different occasions to provide an indication of beta-plus-gamma fields, which are routinely encountered at a DOE separations facility. Both sets of measurements included a process sample and a waste sample. The first measurements at Site $A$ were taken in a laboratory hood in a low-background area. The samples were contained in small glass vials. A silicon detector was placed in the same hood at distances of 30,60 , and $90 \mathrm{~cm}$ from the sample.

Figure 11 shows the beta-energy spectrum for the process sample at $30 \mathrm{~cm}$. The spectrum was obtained by placing $412 \mathrm{mg} / \mathrm{cm}^{2}$ of aluminum absorber in front of the detector and subtracting the resultant spectrum from the beta-plusgamma spectrum (Figure 12). Thus, Figure 11 approximates the beta spectrum; approximately $10 \%$ of the beta particles at higher energies will penetrate the aluminum and thus be subtracted. Also, backscatter of incident low-energy beta particles and $x$-ray attenuation in the absorber cause a possible distortion of the low-energy portion of the spectrum. A comparison of the two spectra reveals that only about one-half of the electrons generated in the detector were due to beta radiation. Compton scattering of photons dominated the spectrum below $200 \mathrm{keV}$. Only gamma radiation was evident above approximately $1000 \mathrm{keV}$.

The same procedure just described was used to obtain spectra for a waste sample during the first measurements at Site A (Figures 13 and 14). Although these spectra appear to be somewhat similar to those of the process sample, the relative intensity of the beta field is much smaller and the endpoint of the beta spectrum is at a lower energy (approximately $620 \mathrm{keV}$ ).

The second set of measurements at Site $A$ was made nearly two years after the first set and under somewhat different conditions. The process sample in 


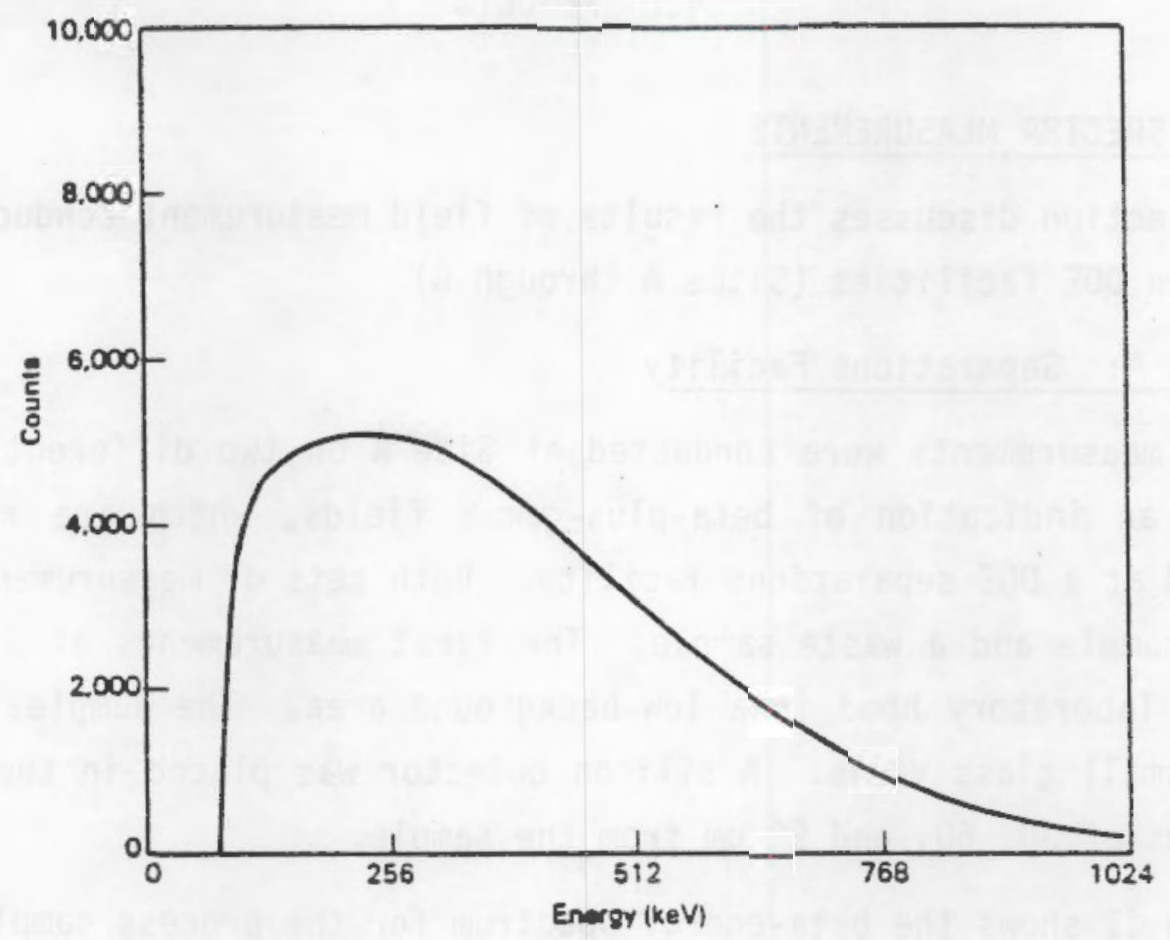

FIGURE 11. Beta Spectrum for the First Process Sample at $30 \mathrm{~cm}$

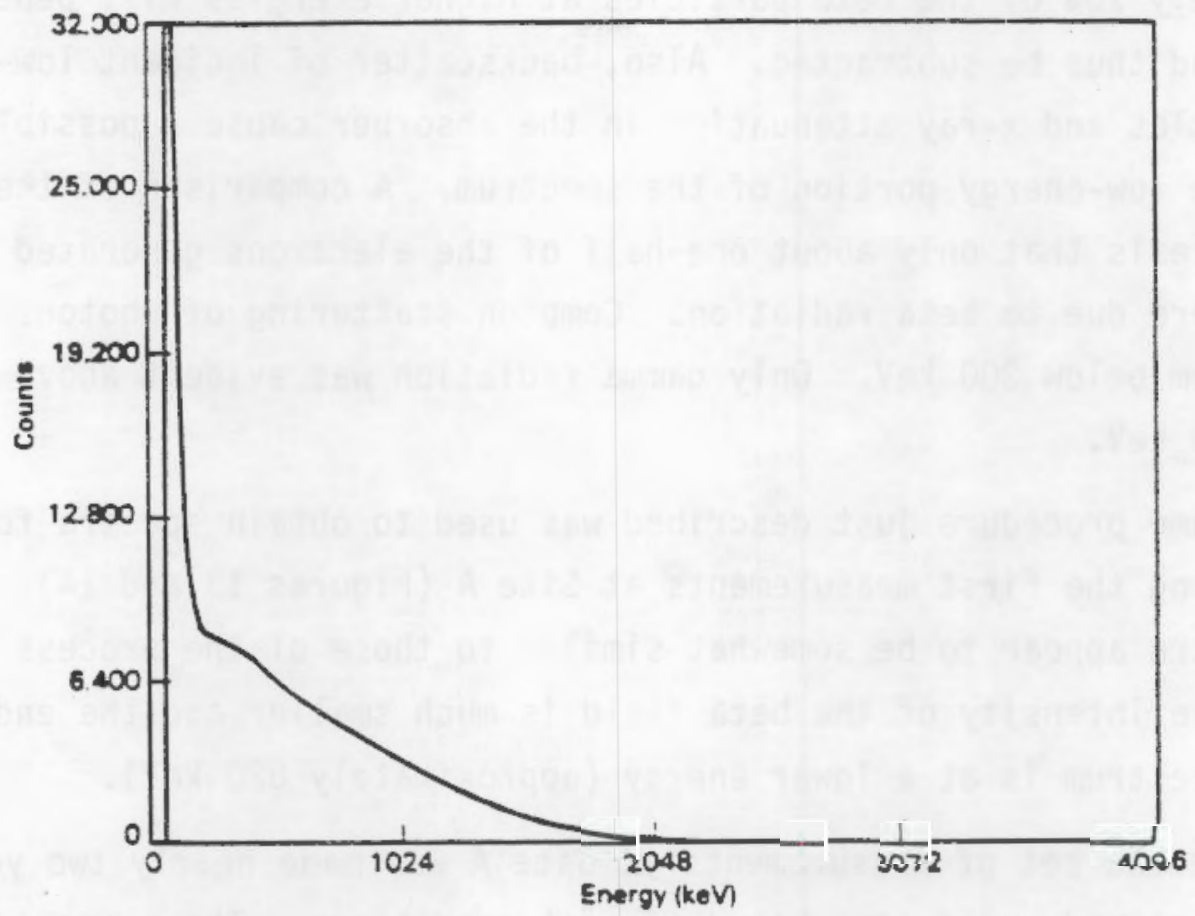

FIGURE 12. Beta-Plus-Gamma Spectrum for the First Process Sample at $30 \mathrm{~cm}$ 


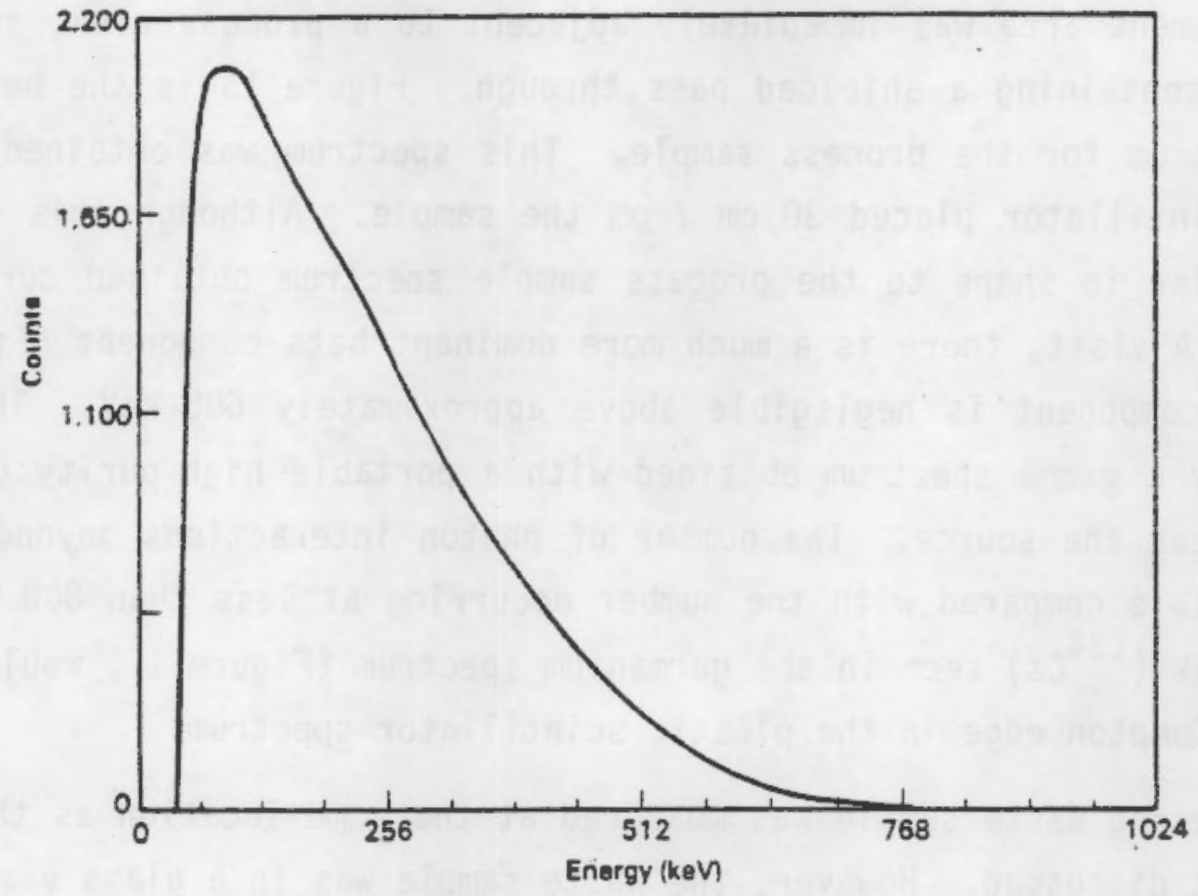

FIGURE 13. Beta Spectrum for the First Waste Sample at $30 \mathrm{~cm}$

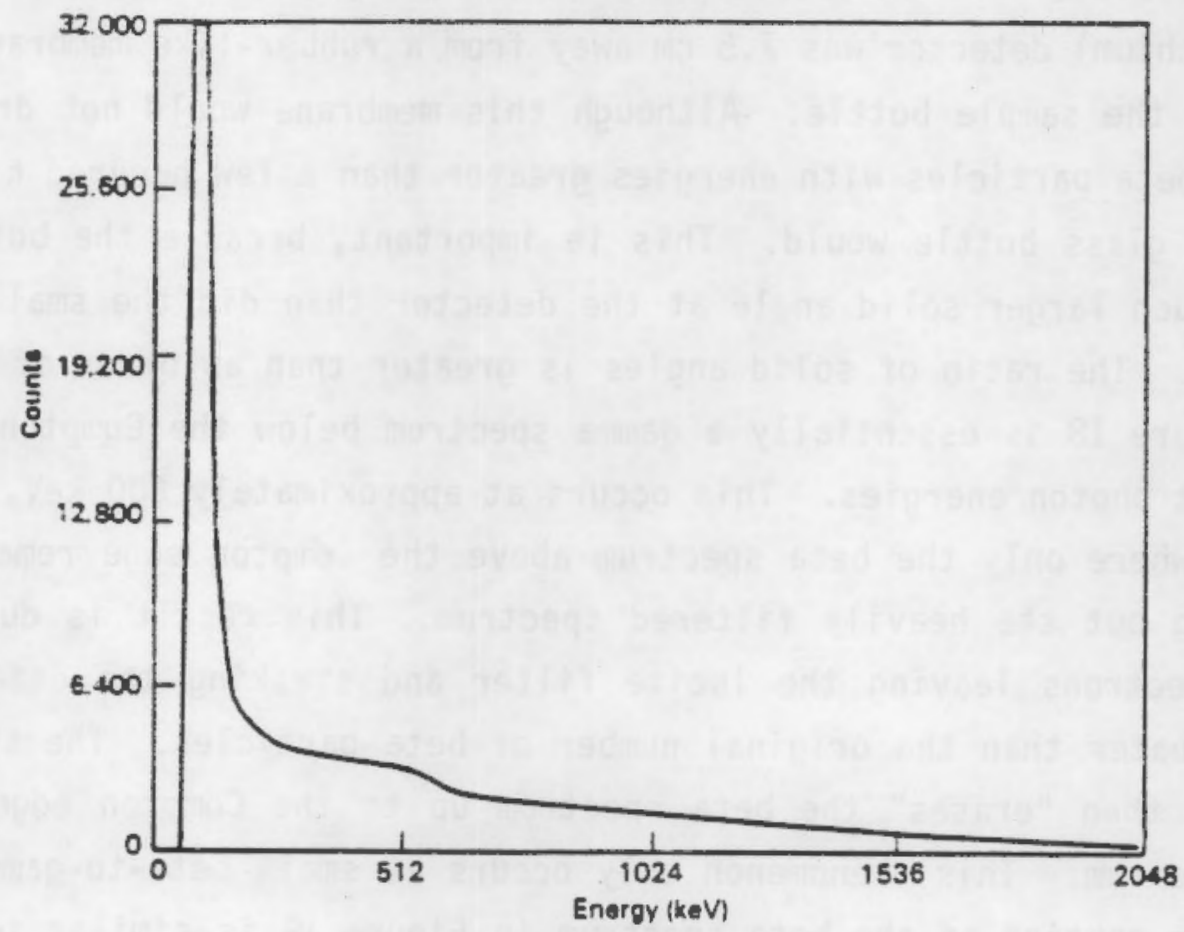

FIGURE 14. Beta-Plus-Ganma Spectrum for the First Waste Sample at $30 \mathrm{~cm}$ 
this instance was in the form of a drop of liquid on a gauze pad. It was placed in a ventilated hood in a relatively high gamma background area. The measurement area was immediately adjacent to a process area, separated by a wall containing a shielded pass through. Figure 15 is the beta-plusgamma spectrum for the process sample. This spectrum was obtained with a plastic scintillator placed $30 \mathrm{~cm}$ from the sample. Although this spectrum looks similar in shape to the process sample spectrum obtained during the first Site A visit, there is a much more dominant beta component (Figure 16); the gamma component is negligible above approximately $600 \mathrm{keV}$. This was verified by a gamma spectrum obtained with a portable high-purity germanium detector near the source. The number of photon interactions beyond $800 \mathrm{keV}$ was negligible compared with the number occurring at less than $800 \mathrm{keV}$. The $796-\mathrm{keV}$ peak $\left({ }^{134} \mathrm{Cs}\right)$ seen in the germanium spectrum (Figure 17) would occur as a 600-keV Compton edge in the plastic scintillator spectrum.

The second waste sample was measured at the same location as the process sample just discussed. However, the waste sample was in a glass vial within a lead pig. The beta-plus-gamma spectrum that was obtained with a silicon (1ithium) surface barrier detector is shown in Figure 18. The window of the silicon(1ithium) detector was $7.5 \mathrm{~cm}$ away from a rubber-like membrane covering the top of the sample bottle. Although this membrane would not drastically attenuate beta particles with energies greater than a few hundred kiloelectron volts, the glass bottle would. This is important, because the bottle subtended a much larger solid angle at the detector than did the small membrane at the top. The ratio of solid angles is greater than an order of magnitude. Hence, Figure 18 is essentially a gamma spectrum below the Compton edge for the highest photon energies. This occurs at approximately $600 \mathrm{keV}$, as seen in Figure 19 where only the beta spectrum above the Compton edge remains after subtracting out the heavily filtered spectrum. This result is due to the Compton electrons leaving the lucite filter and striking the detector in numbers greater than the original number of beta particles. The subtraction of spectra then "erases" the beta spectrum up to the compton edge of the photon spectrum. This phenomenon only occurs at small beta-to-gamma ratios. The visible portion of the beta spectrum in Figure 19 is similar to that for the process sample. 


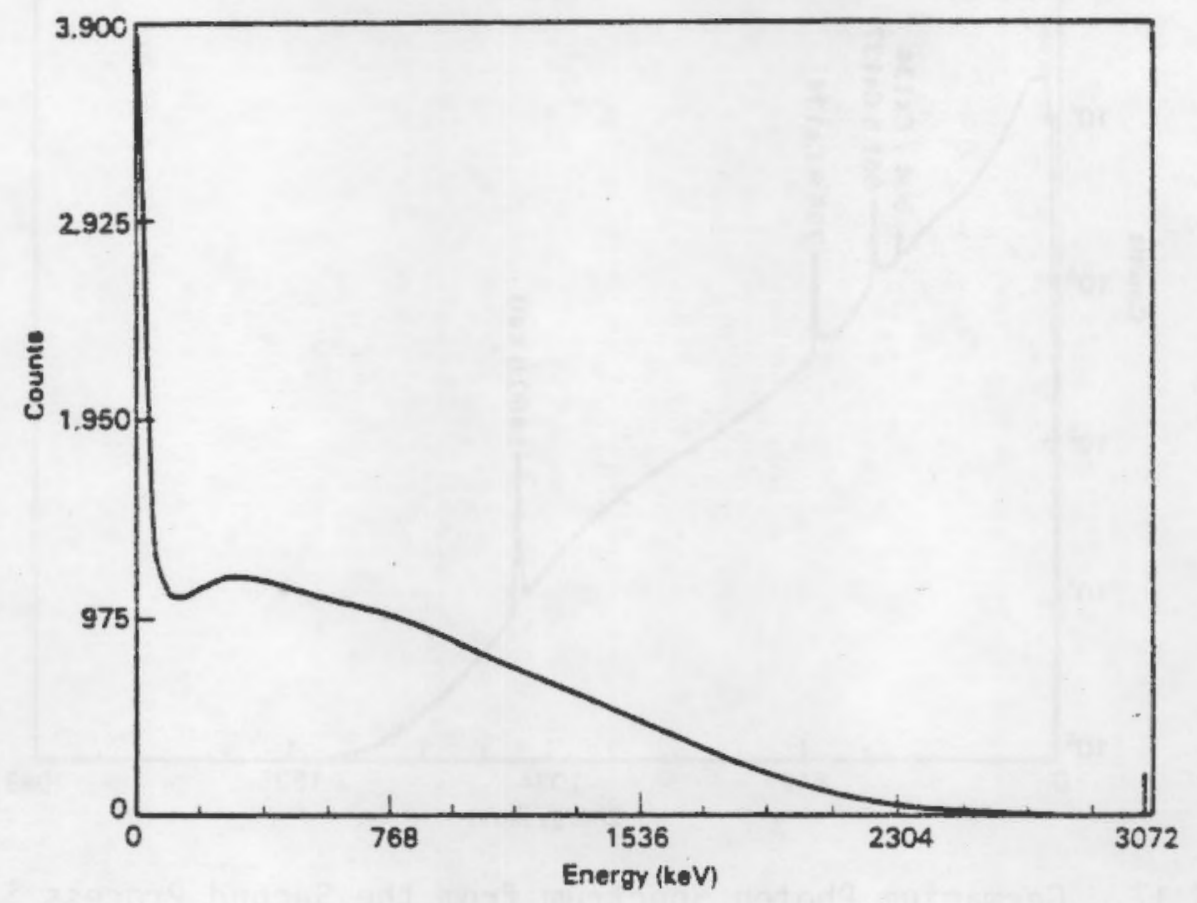

FIgURE 15. Combined Beta-Plus-Gamma Spectrum from the Second Process Sample

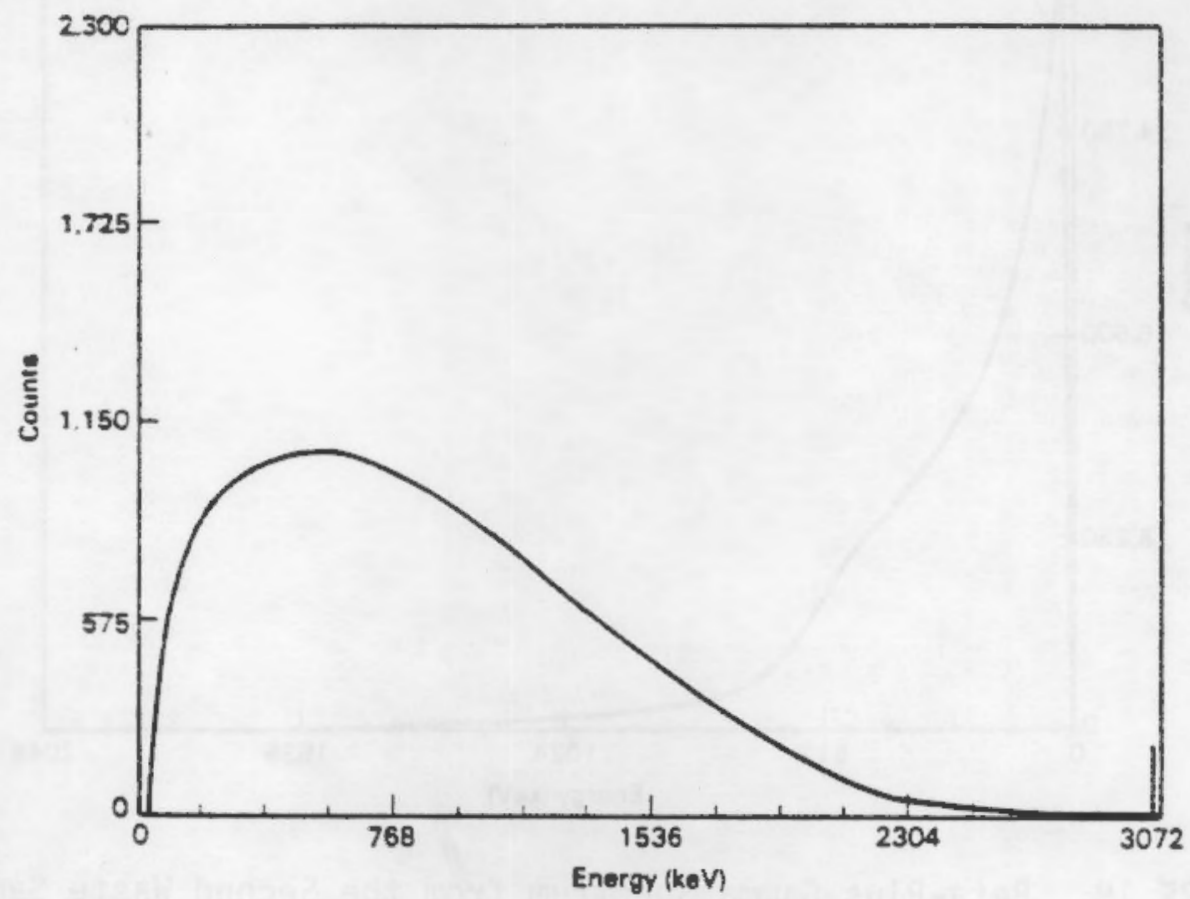

FIGURE 16. Beta-Only Spectrum from the Second Process Sample 


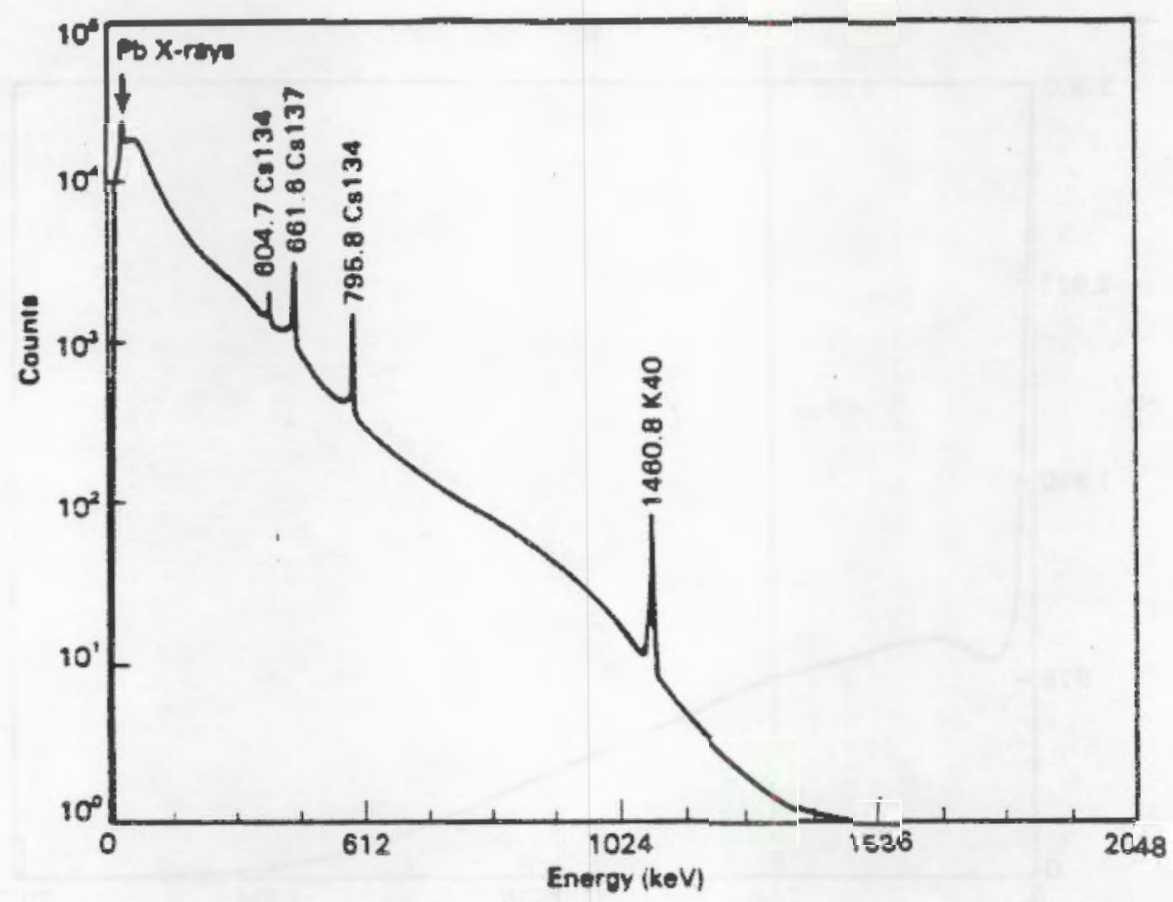

FIGURE 17. Germanium Photon Spectrum from the Second Process Sample

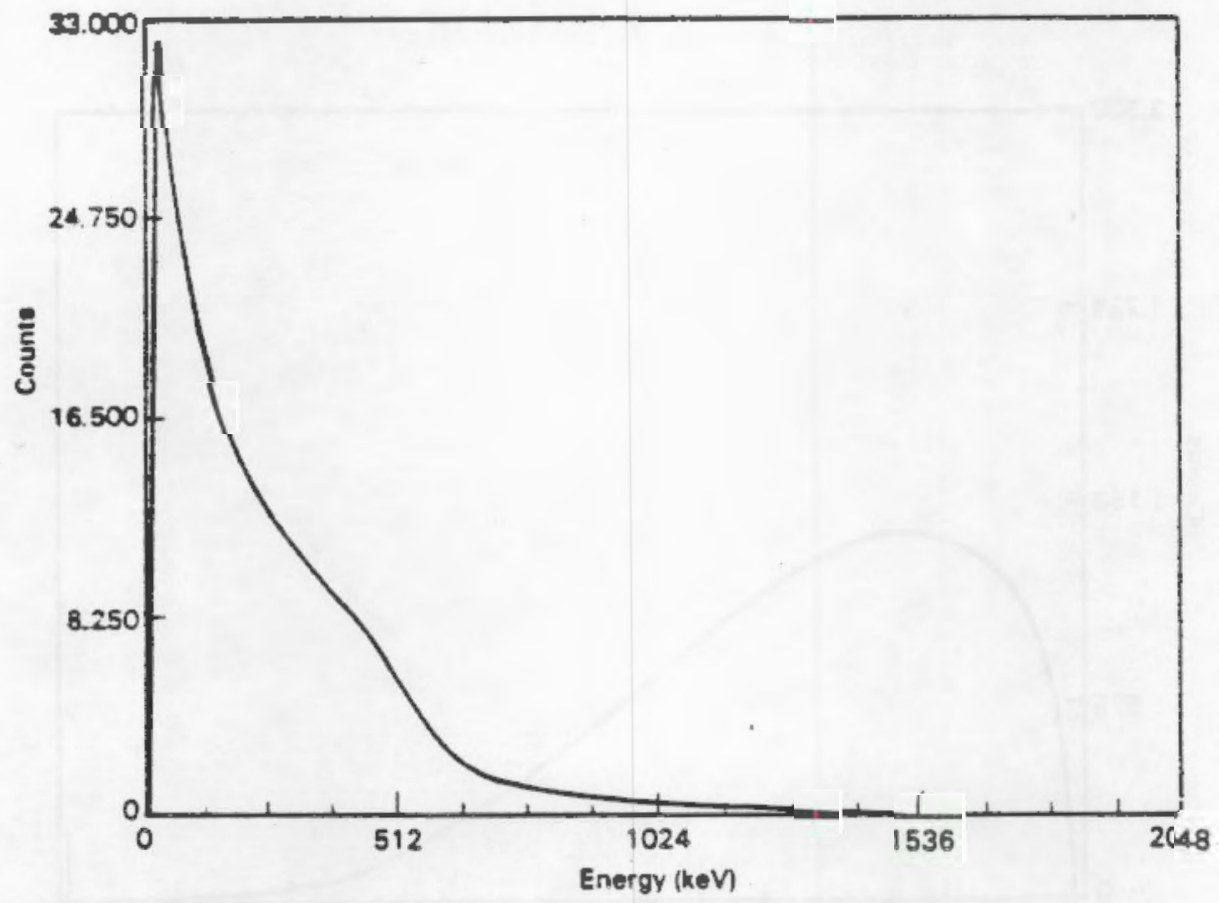

FIGURE 18. Beta-Plus-Gamma Spectrum from the Second Waste Sample 


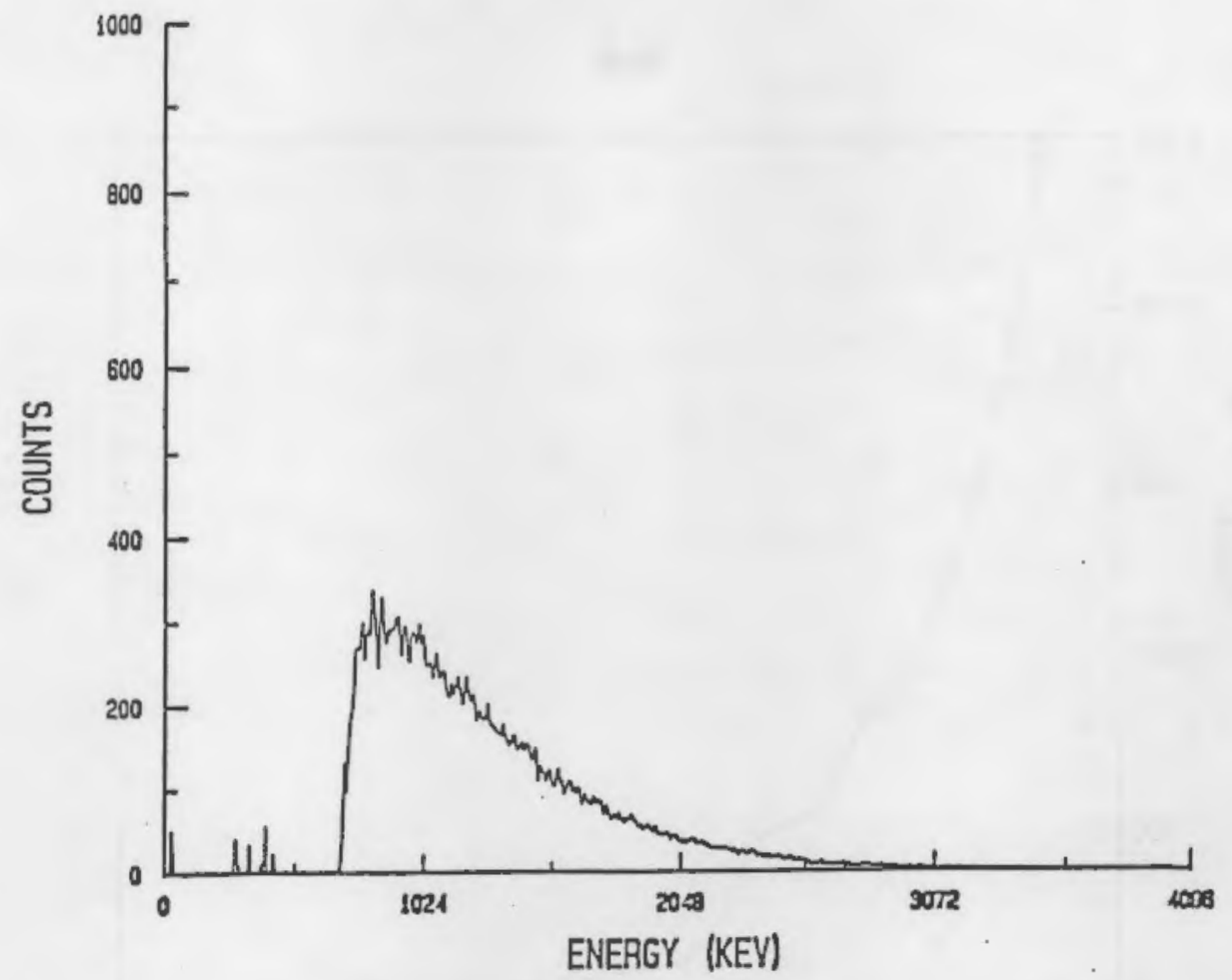

FIGURE 19. Beta-0nly Spectrum from the Second Waste Sample

\subsubsection{Site B: Fuel Fabrication Facility}

Field measurements taken at Site $B$ provide an indication of betaplus-gamma fields, which are routinely encountered with clad fuel at a DOE fuel fabrication facility. Two $50-\mathrm{cm}-1$ ong, $7-\mathrm{cm}-\mathrm{dia}$ fuel element sections, one $0.95 \%$ enriched in ${ }^{235} U$ and the other $1.25 \%$ enriched in ${ }^{235} U$, were measured to provide typical spectral information. A plastic scintillator, a silicon surface barrier detector, and a high-purity germanium detector were used for this study.

Measurement instruments and fuel elements were arranged on carts in the building containing the fuel fabrication operations. All beta spectroscopy measurements were performed with detectors at one-half inch from the surface of the fuel elements, midway between the ends.

The beta and gamma spectra are compared in Figures 20 through 22 . Most of the counts in the mixed spectrum (Figure 20) are due to the Compton scattering of photons. When the beta particles were removed by a plastic filter, the remaining spectrum (Figure 21) was virtually the same as Figure 20. The subtraction of spectra shows the beta spectrum (Figure 22), which is very 


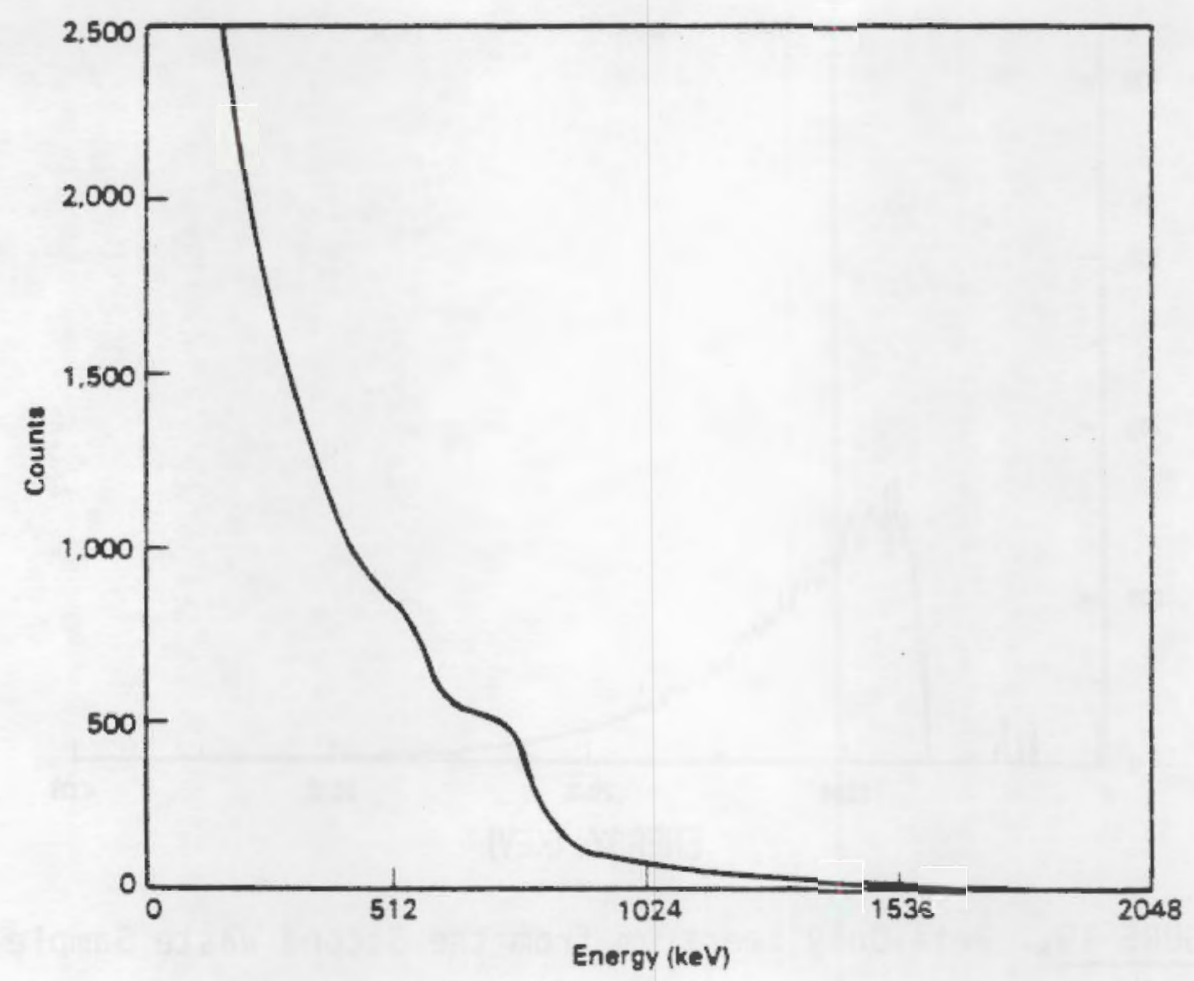

FIGURE 20. Beta-Plus-Gamma Spectrum for the 1.25\%-Enriched Fuel Element

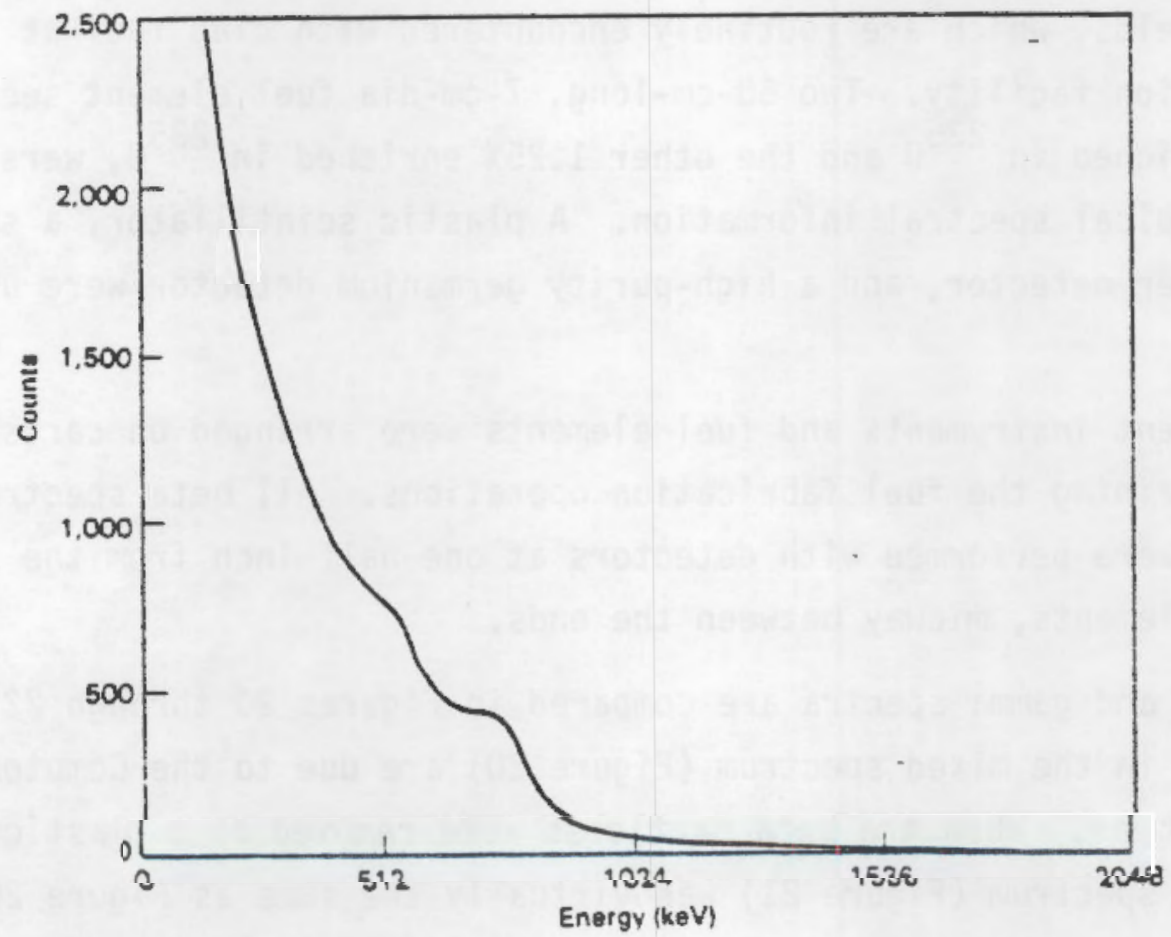

FIGURE 21. Gamma Spectrum for the 1.25\%-Enriched Fuel Element 


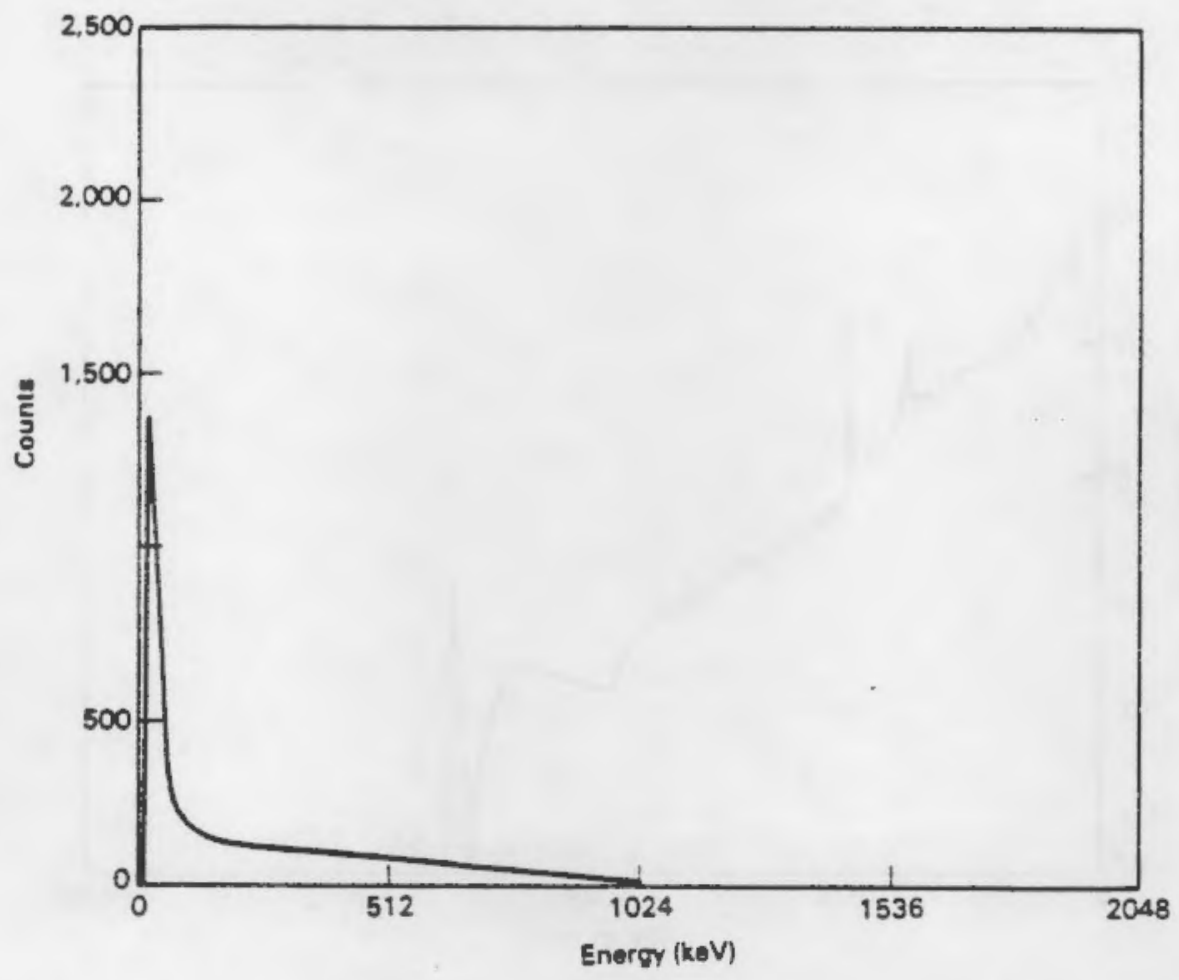

FIGURE 22. Beta Spectrum for the $1.25 \%$-Enriched Fuel Element

low in intensity due to attenuation by the fuel element cladding ( $2 \mathrm{~mm}$ of zirconium).

Figures 23 and 24 show the gamma spectra of the $0.95 \%$ and $1.25 \%$ enriched fuel elements. Both spectra are practically identical except for the 185.7-keV gamma ray from ${ }^{235} \mathrm{U}$ being more prominent in Figure 25.

\subsubsection{Site C: Separations Facility}

At Site $\mathrm{C}$, another separations facility, beta spectral measurements were taken in an analytical laboratory on samples from eight liquid waste tanks. All but one of the spectra were characterized with a scintillation detector. The liquid samples were stored together in one section of the laboratory. Each liquid sample was contained in a small (less than $10 \mathrm{ml}$ ) glass or plastic bottle ( $\cong 1.6-\mathrm{cm}$ dia $\times 5.0-\mathrm{cm}$ high). These bottles, typically one-half full, were stored inside small lead pigs with two bottles per pig.

Prior to beta analyses, each lead pig was taken to a low-background portion of the laboratory and placed inside a hood where the beta analysis 


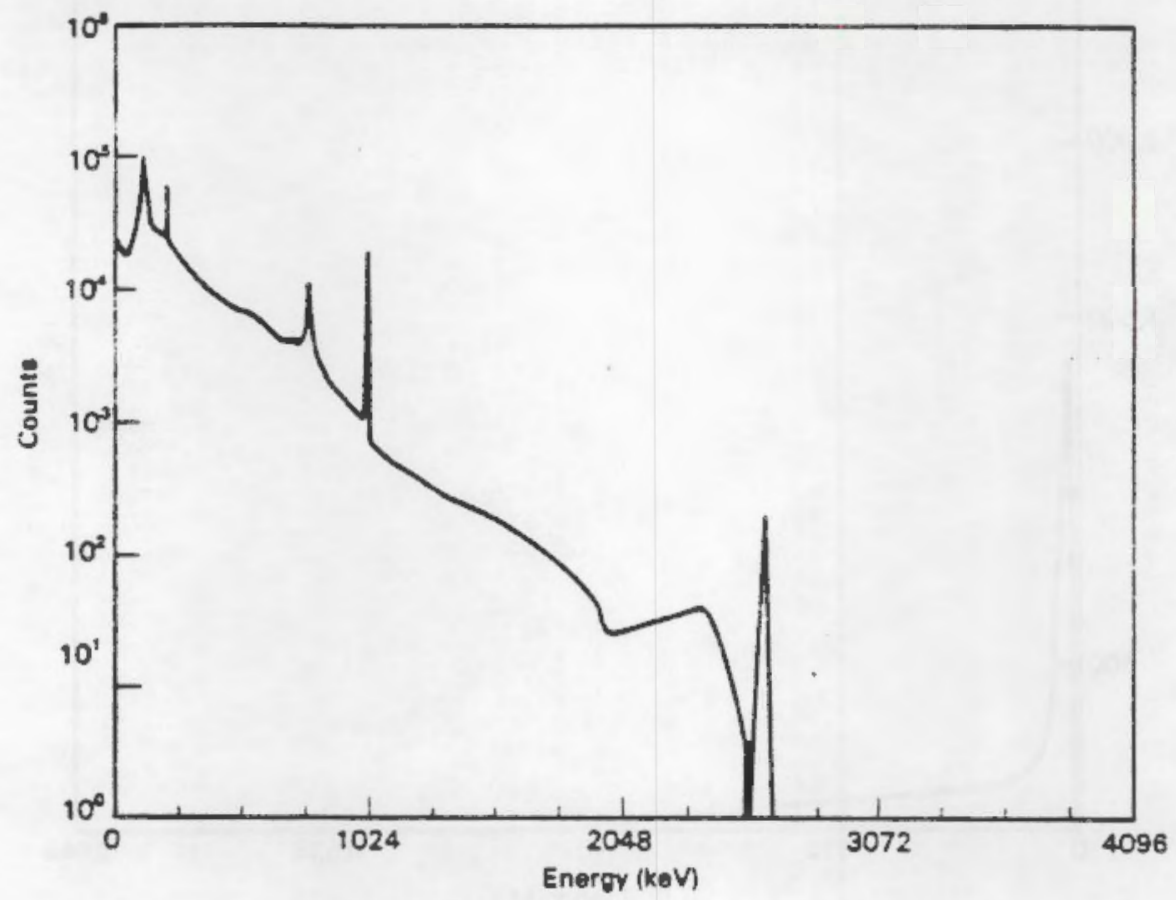

FIGURE 23. Germanium Gamma Spectrum for the $1.25 \%$-Enriched Fuel Element

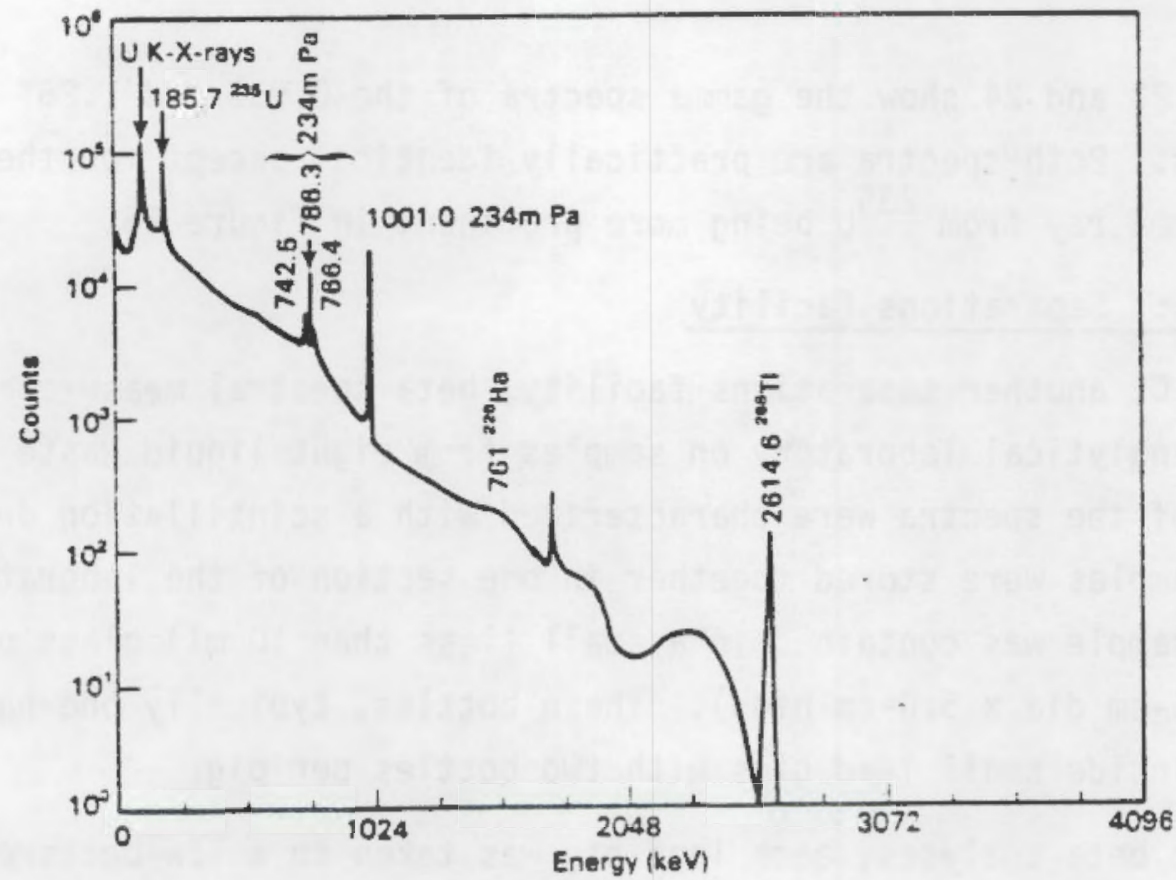

FIGURE 24. Germanium Gamma Spectrum for the 0.95\%-Enriched Fuel Element 
system was set up. The face of the beta detector was suspended $10 \mathrm{~cm}$ above the floor of the hood. This allowed the liquid samples to be placed, one at a time, into a glass beaker and slid under the detector. Metal tongs and long tweezers were used to place the sample bottles into the beaker and remove the lids. As soon as the lids were removed, "Cutie Pie" (CP) readings were taken for comparison with spectral results. With the arrangement described, the face of the beta detector was $2.5 \mathrm{~cm}$ from the top of the sample bottles, and typically $5 \mathrm{~cm}$ from the liquid surface, although there was a $2-\mathrm{cm}$ variation between the lowest and highest liquid level. The outside of the bottles were slightly contaminated. In some cases, the photon contribution from the sample still in the lead pig complicated the spectrum from the sample being analyzed. Even with these variables, the relationship between the detectors and the samples constituted a situation seldom seen in field studies, i.e., a small beam of beta particles nearly perpendicular to the detector face.

Figure 25 shows the combined beta-plus-gamma spectrum, and Figure 26 shows the beta-only spectrum from the first tank sample (taken from Tank 105AW). Although the Compton-scattering of photons contributes more than half

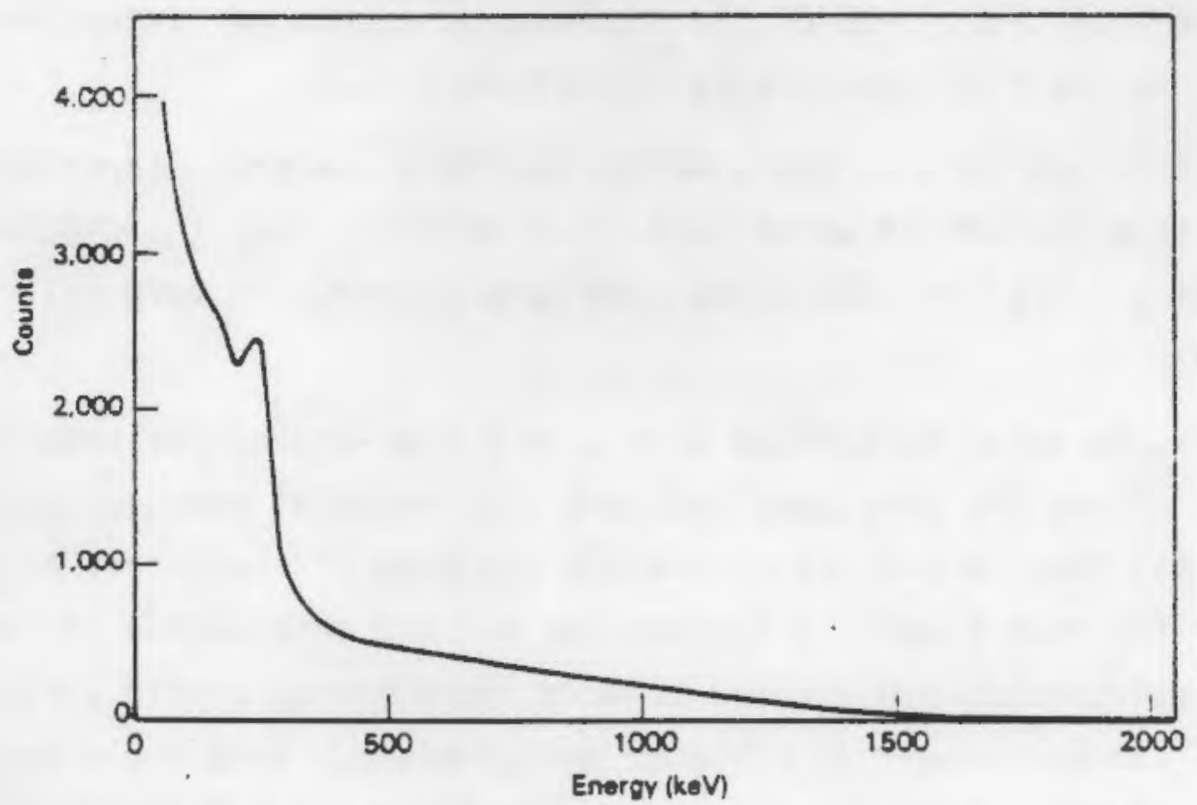

FIGURE 25. Beta-Plus-Gamma Spectrum for the Sample from Tank 105AW 


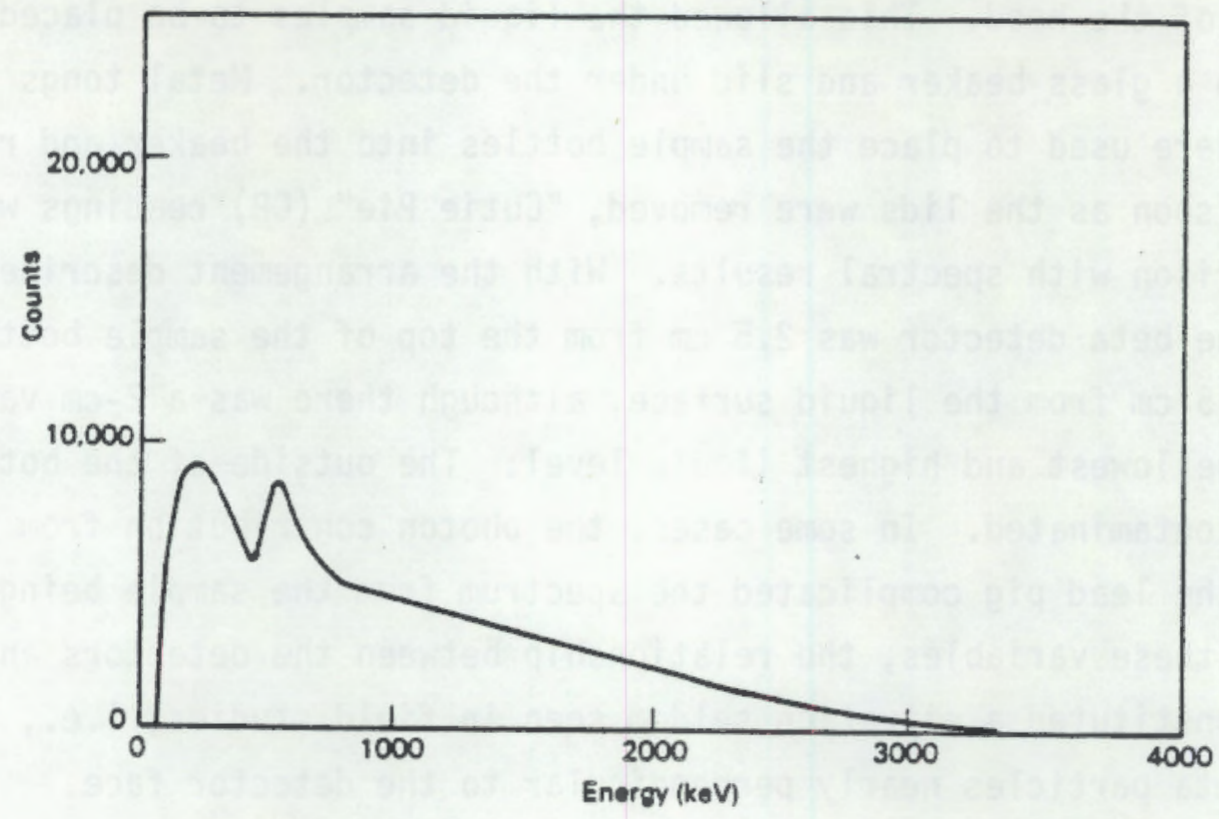

FIGURE 26. Beta Spectrum for the Sample from Tank 105AW

of the events at energies less than $500 \mathrm{keV}$, the beta spectrum from ${ }^{137} \mathrm{Cs}$ is very evident in this same region. The conversion electron peak from ${ }^{137} \mathrm{Cs}$ is seen in Figure 26 between 500 and $700 \mathrm{keV}$. There are high-energy beta particles in the spectrum; some of the high-energy counts may arise from pulse summing due to the high count rates (dead time $=45 \%$ ).

Figures 27 and 28 show the combined and beta spectra, respectively for the sample from the second waste tank (Tank 107AN). When the photon contribution (probably ${ }^{137} \mathrm{Cs}$ ) is subtracted, the beta spectrum is very well defined and intense.

However, to date, no nuclide with such a high-energy spectrum has been identified. There are many beta emitters with endpoint energies greater than $4 \mathrm{MeV}$, but all have very short half-lives and none of these have a long-lived precursor. The most plausible explanation for the observation is pulse pileup in the analysis system causing two or more lower energy events (less than $2.5 \mathrm{MeV}$ ) to sum and appear as a higher energy event. This would explain events above $3 \mathrm{MeV}$. The spectrum is thought to be accurate below $3 \mathrm{MeV}$. 


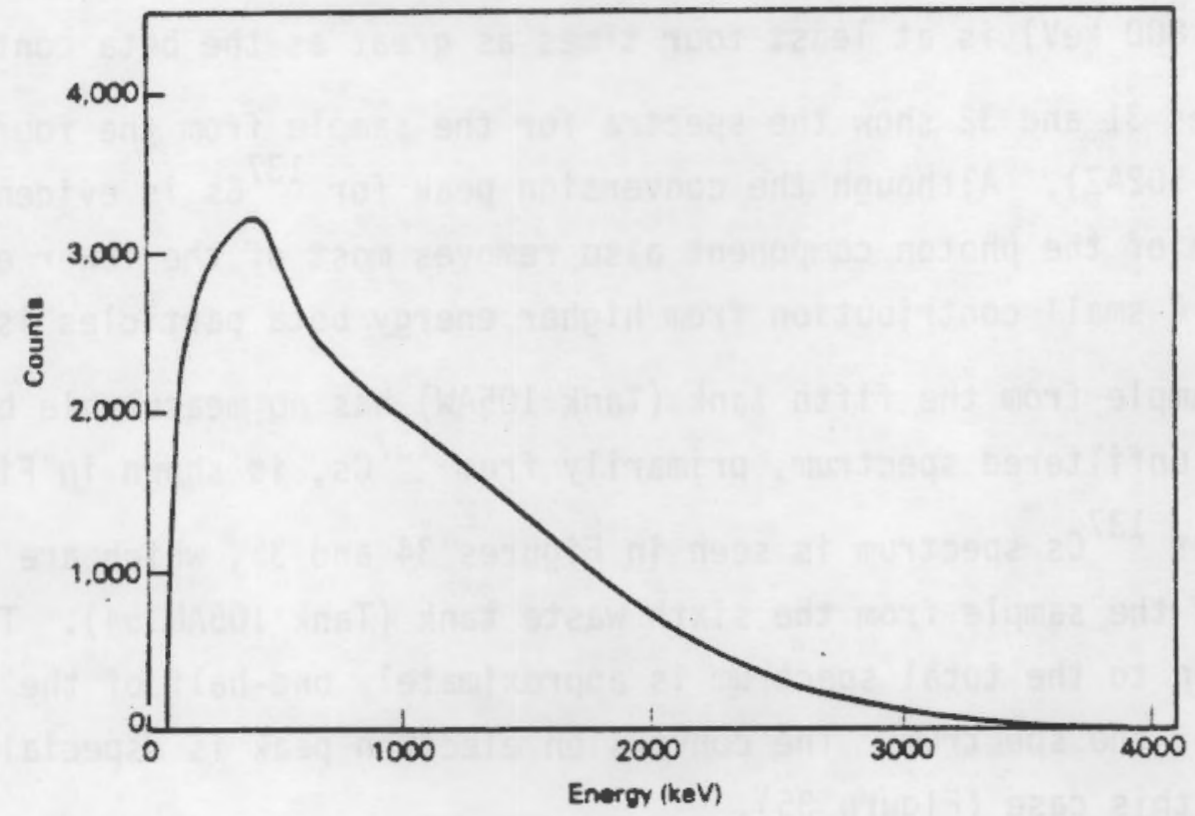

FIGURE 27. Beta-Plus-Gamma Spectrum for the Sample from Tank 107AN

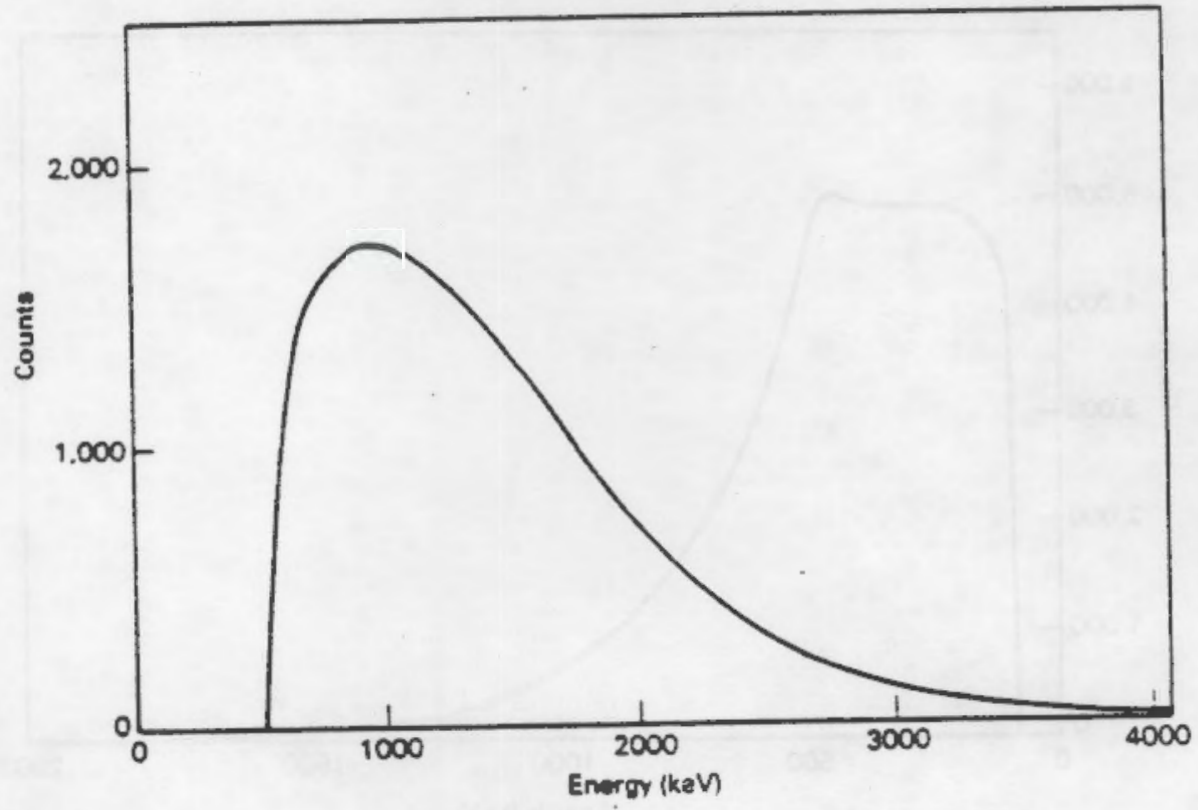

FIGURE 28. Beta Spectrum for the Sample from Tank 107AN 
The spectra for the sample from the third waste tank (Tank 105AN), Figures 29 and 30 , show ${ }^{137} \mathrm{Cs}$ and a very small contribution from a higher energy beta emitter, probably ${ }^{90} \gamma$. The photon contribution at lower energies (less than $800 \mathrm{keV}$ ) is at least four times as great as the beta contribution.

Figures 31 and 32 show the spectra for the sample from the fourth waste tank (Tank 102AZ). Although the conversion peak for ${ }^{137} \mathrm{Cs}$ is evident, the subtraction of the photon component also removes most of the lower energy beta spectrum. A small contribution from higher energy beta particles is evident.

The sample from the fifth tank (Tank 105AW) has no measurable beta spectrum. The unfiltered spectrum, primarily from ${ }^{137} \mathrm{Cs}$, is shown in Figure 33 . Another ${ }^{137} C_{S}$ spectrum is seen in Figures 34 and 35 , which are based on analyses of the sample from the sixth waste tank (Tank 105AN154). The beta contribution to the total spectrum is approximately one-half of the total amplitude of the spectrum. The conversion electron peak is especially well defined in this case (Figure 35 ).

The spectra from the sample from the seventh waste tank (Tank 104AN272) are also ${ }^{137} \mathrm{Cs}$ spectra. The presence of ${ }^{239} \mathrm{~Np}$, known to be present due to a

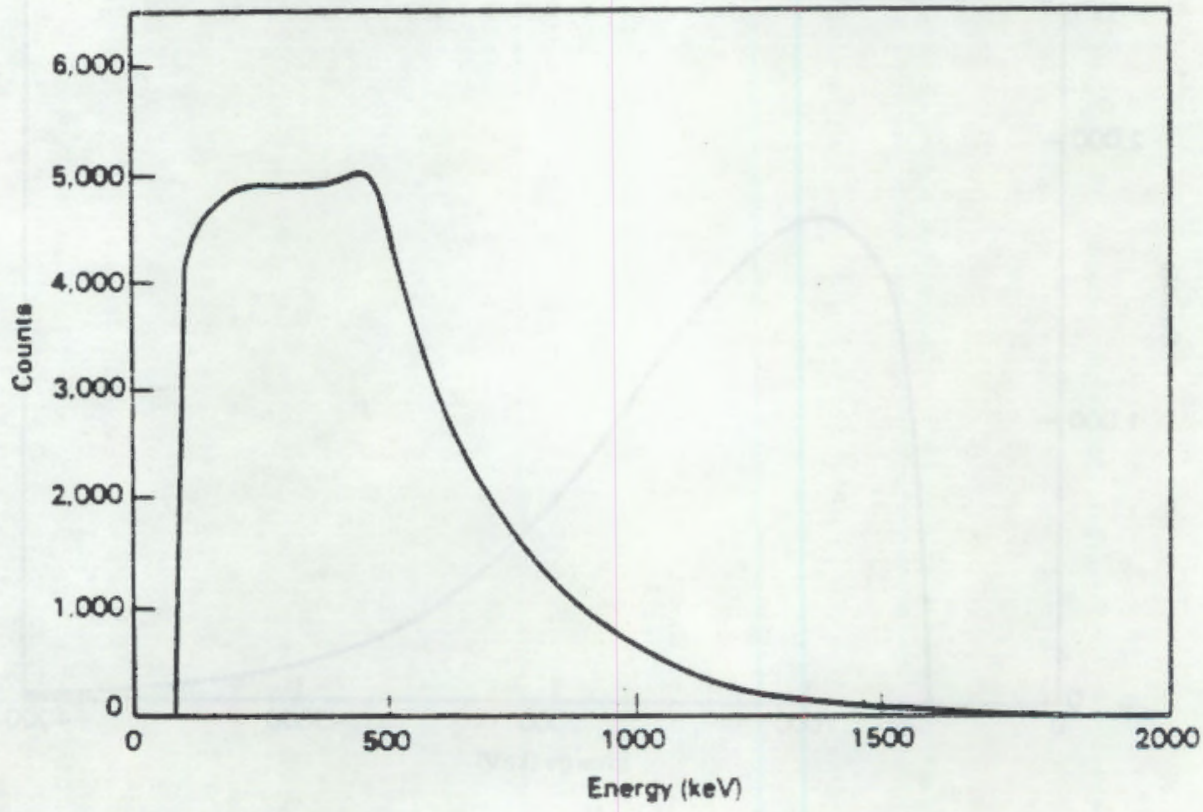

FIGURE 29. Beta-Plus-Gamma Spectrum for the Sample from Tank 105AN 


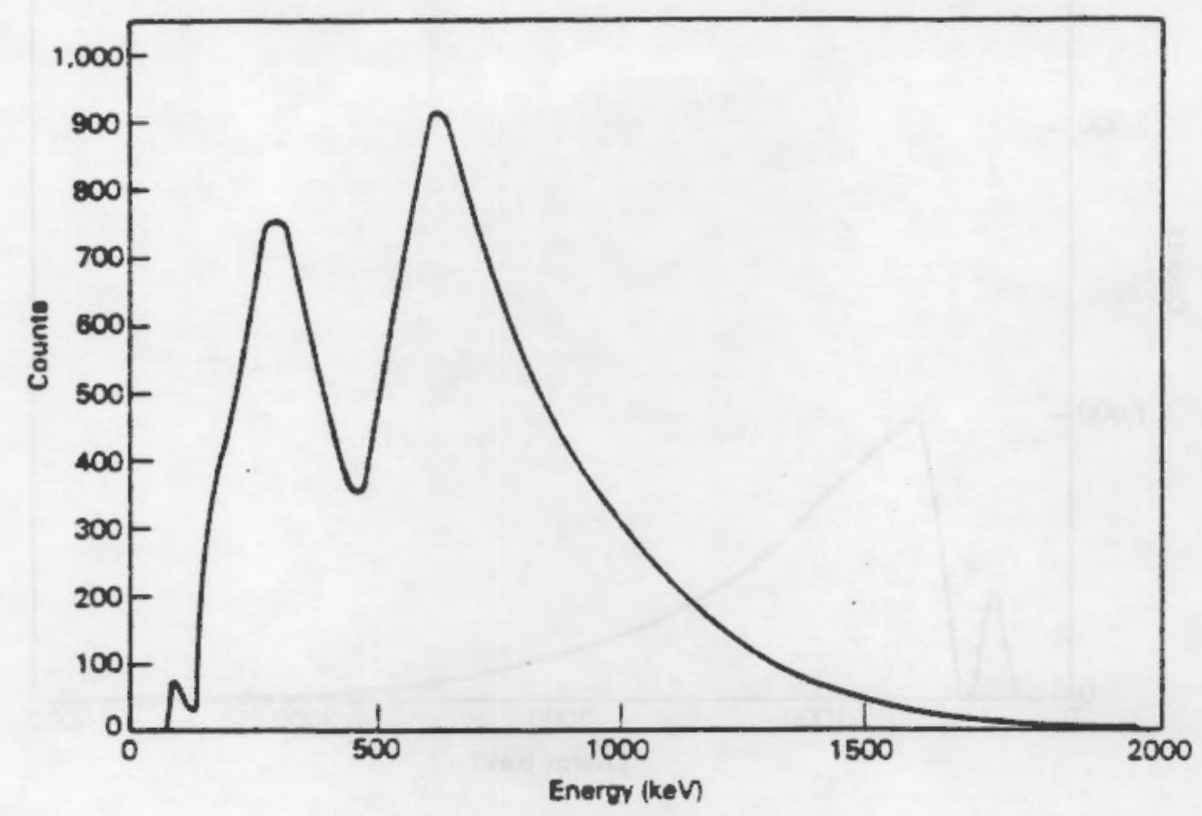

FIGURE 30. Beta Spectrum for the Sample from Tank 105AN

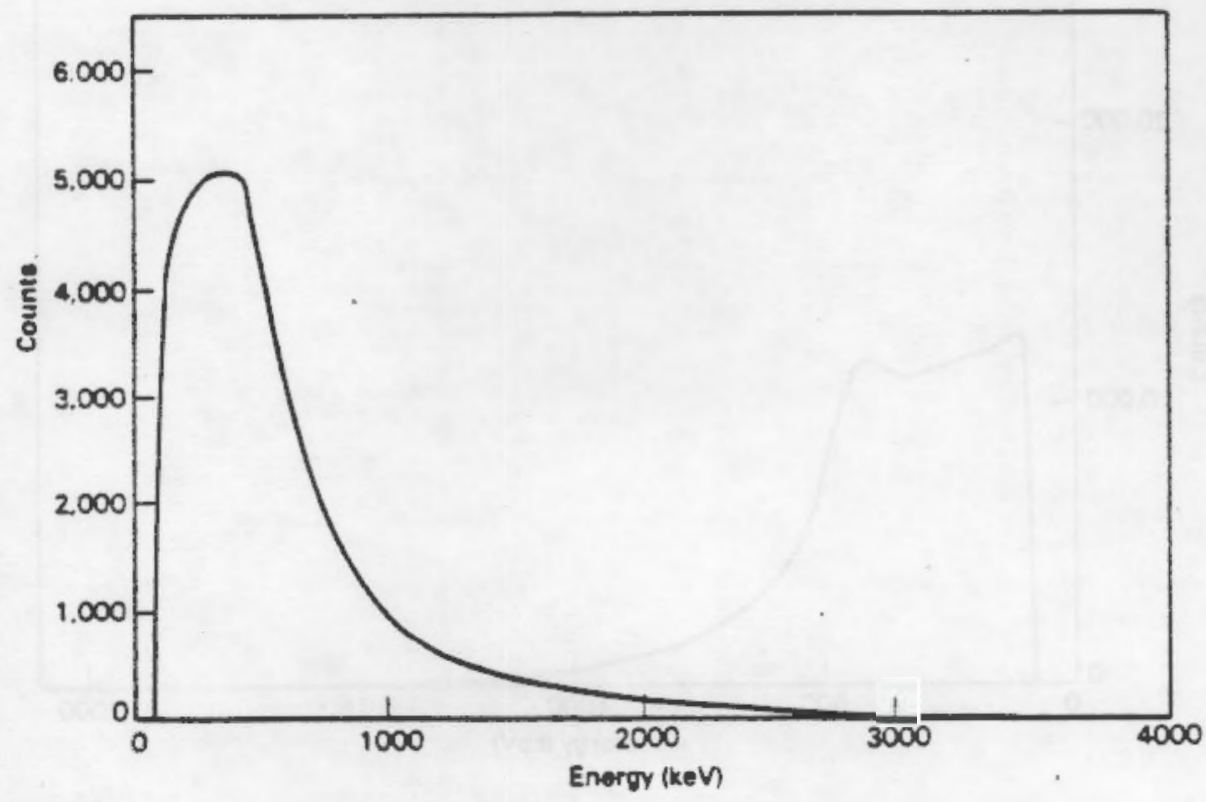

FIGURE 31. Beta-Plus-Gamma Spectrum for the Sample from Tank 102AZ 


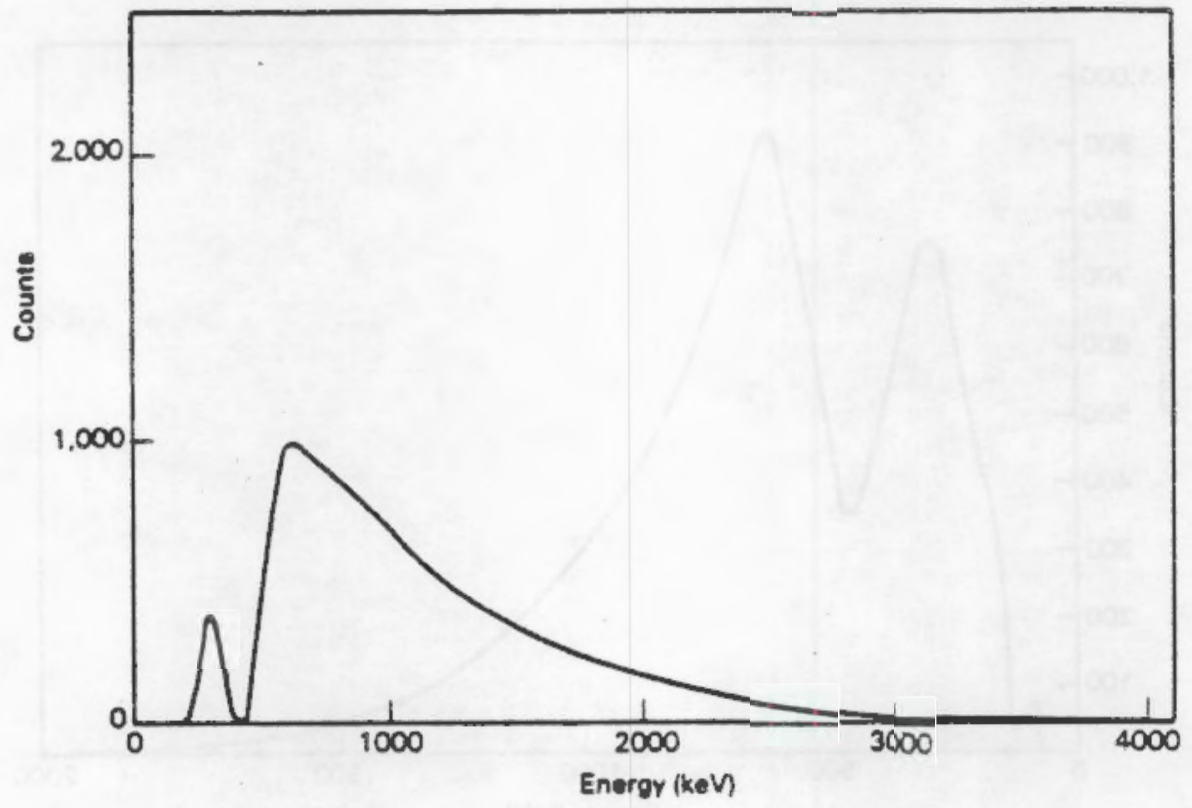

FIGURE 32. Beta Spectrum for the Sample from Tank $102 A Z$

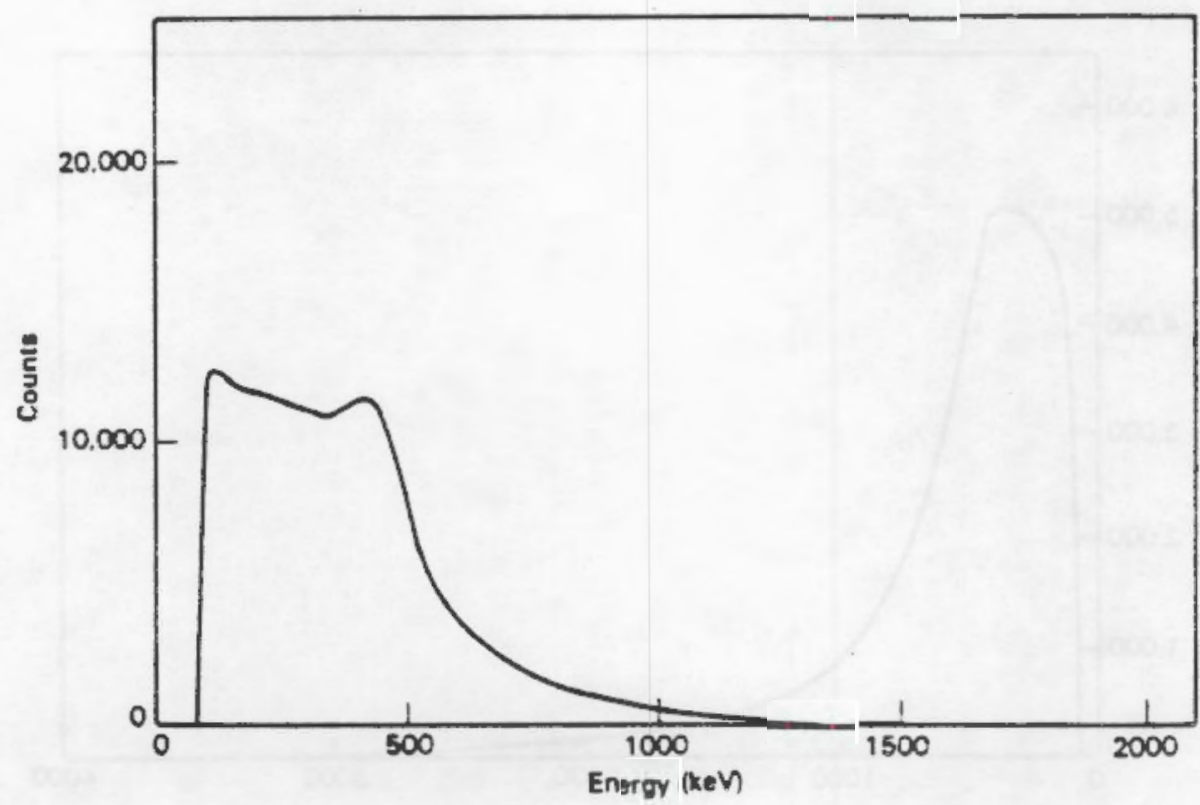

FIGURE 33. Gamma Spectrum for the Sample from Tank 105 AN77 


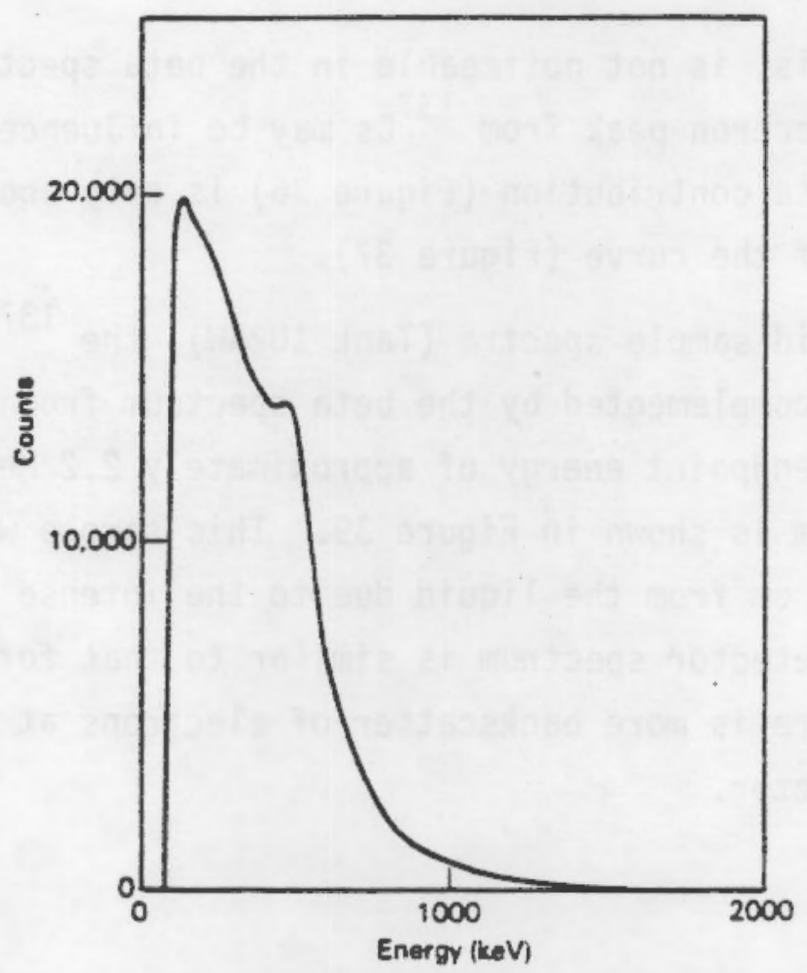

FIGURE 34. Beta-Plus-Gamma Spectrum for the Sample from Tank 105AN154

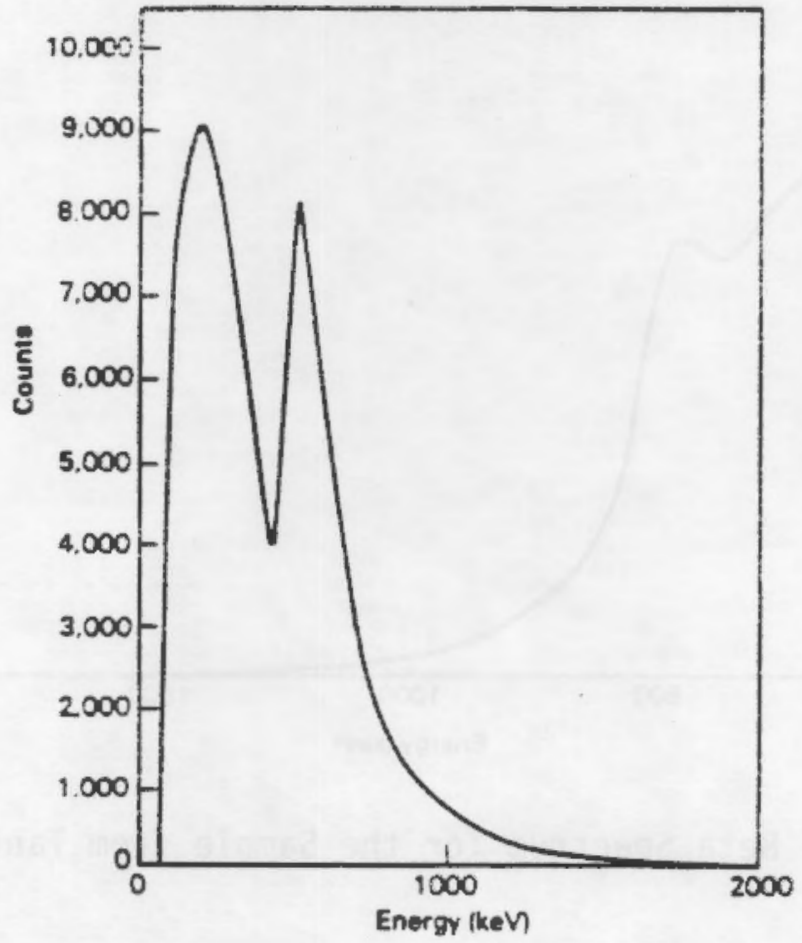

FIGURE 35. Beta Spectrum for the Sample from Tank 105AN154 
gamma spectral analysis, is not noticeable in the beta spectrum, but the 111 defined conversion electron peak from ${ }^{137} \mathrm{C}$ s may be influenced by the presence of the ${ }^{239} \mathrm{~Np}$. The beta contribution (Figure 36 ) is only about one quarter of the total amplitude of the curve (Figure 37 ).

In the last liquid sample spectra (Tank 102AW), the ${ }^{137} C_{S}$ spectrum (beta-plus-gamma) is complemented by the beta spectrum from a higher energy beta emitter with an endpoint energy of approximately $2.2 \mathrm{MeV}$ (Figure 38 ). The beta-only spectrum is shown in Figure 39. This sample was analyzed with a silicon detector at $7 \mathrm{~cm}$ from the liquid due to the intense beta-plus-gamma field. The silicon detector spectrum is similar to that for the scintillator used earlier, but there is more backscatter of electrons at lower energies with the silicon detector.

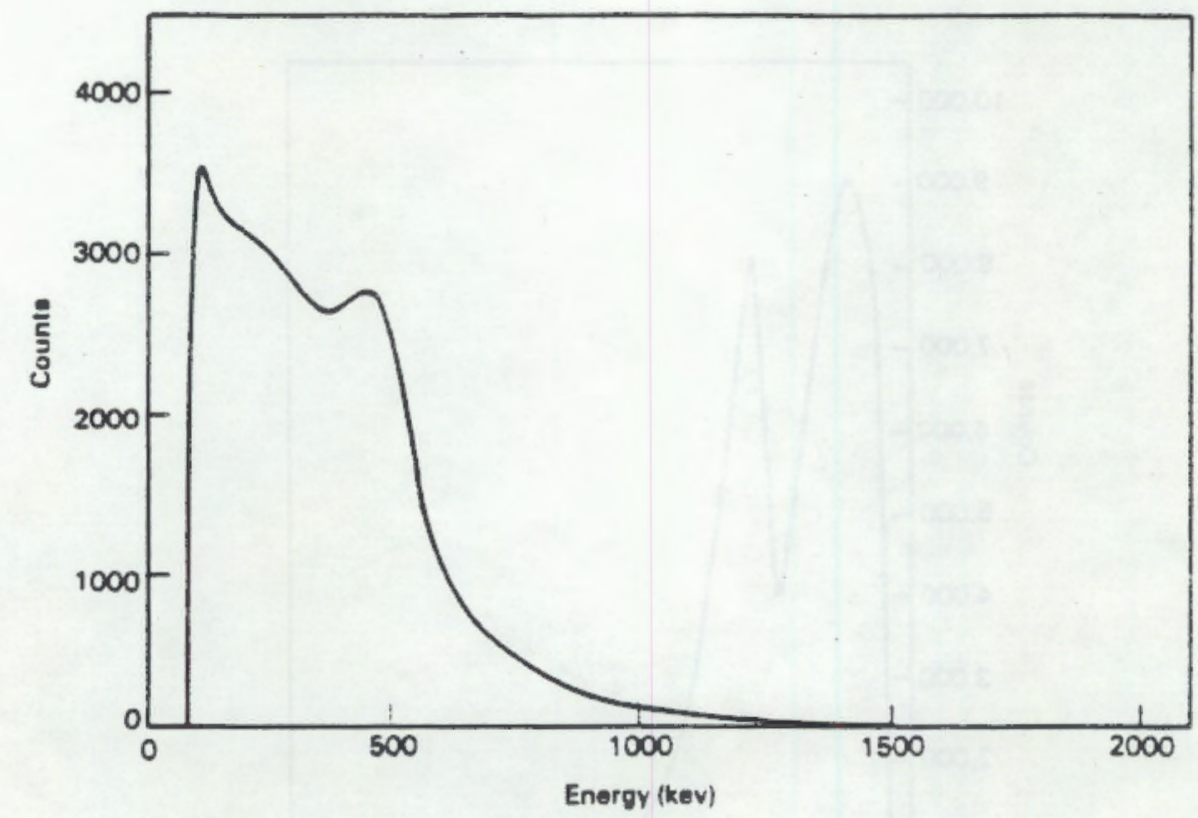

FIGURE 36. Beta Spectrum for the Sample from Tank 104 AN272 


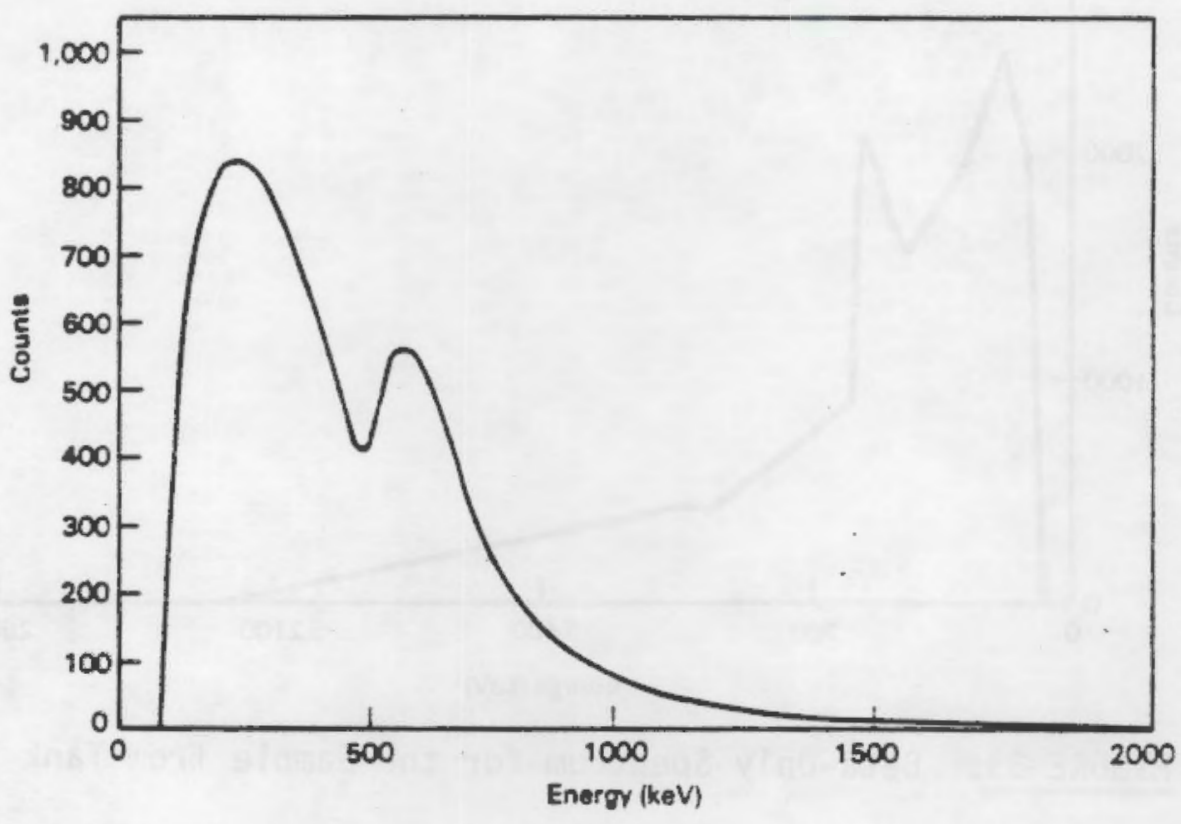

FIGURE 37. Beta-Plus-Gamma Spectrum for the Sample from Tank 104 AN272

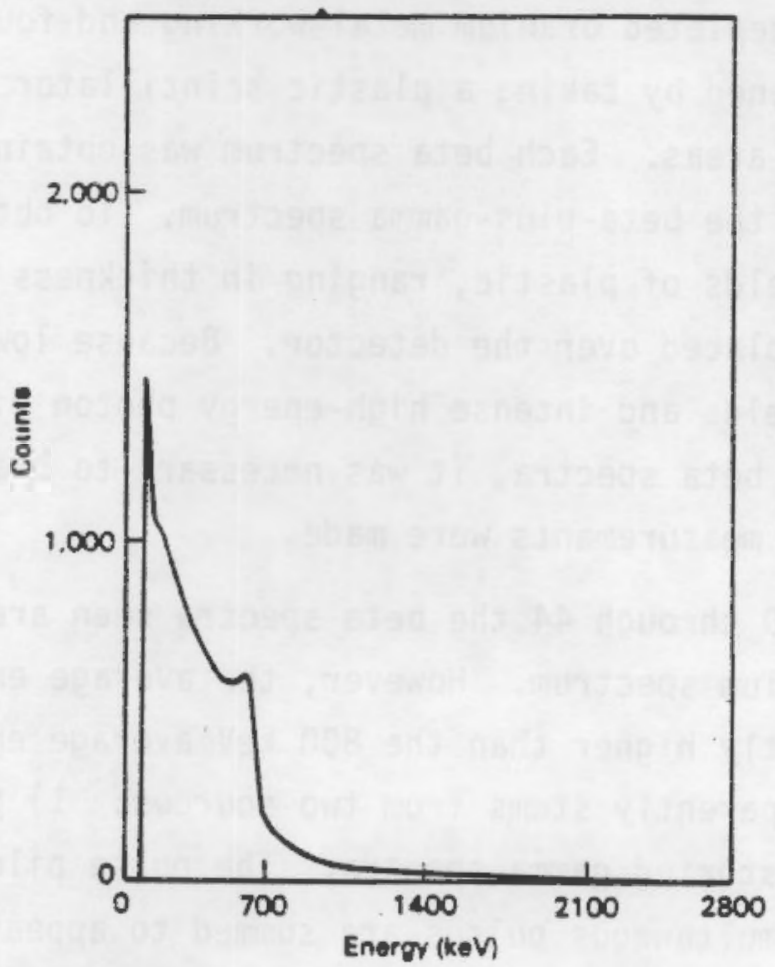

FIGURE 38. Beta-Plus-Gamma Spectrum for the Sample from Tank 102AW 


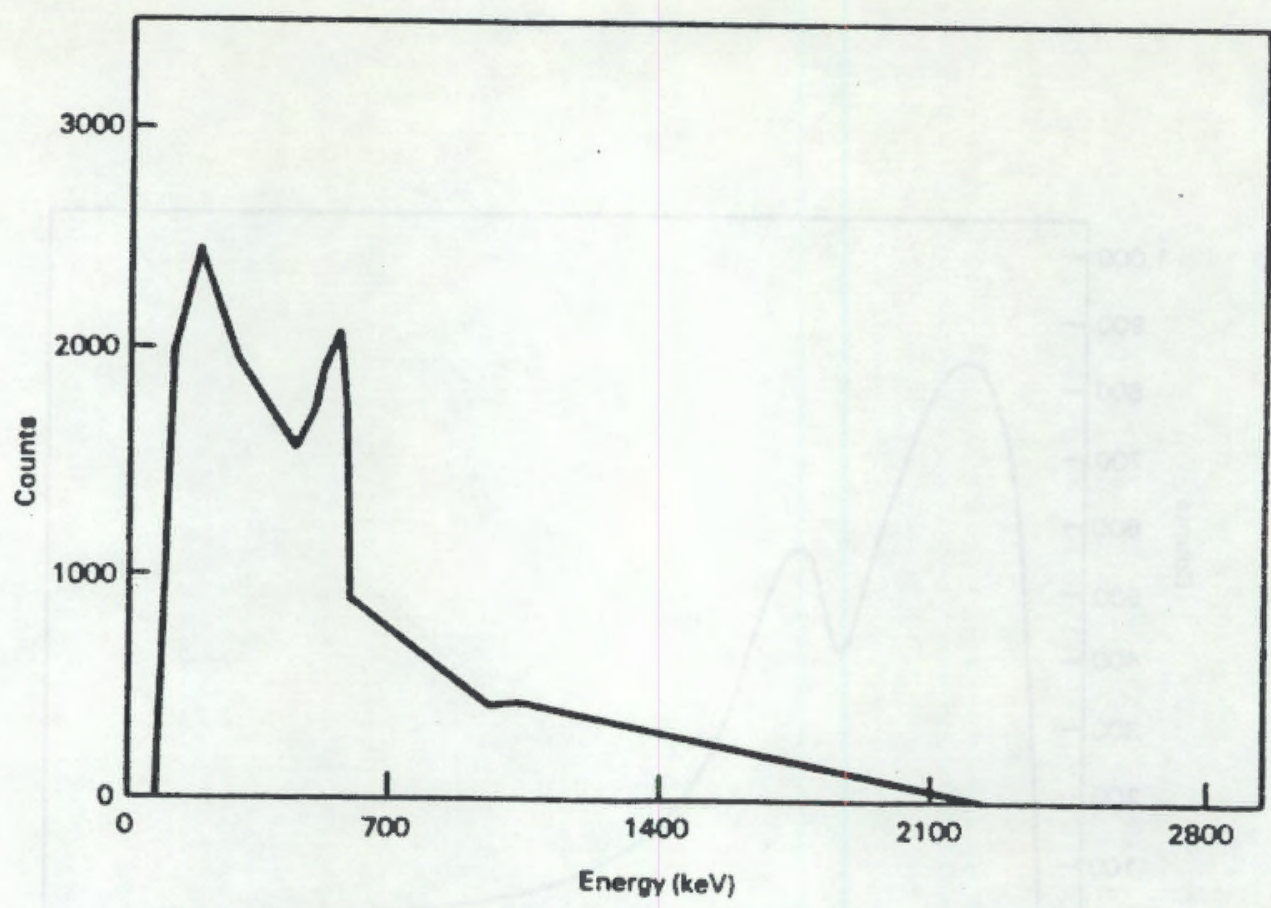

FIGURE 39. Beta-Only Spectrum for the Sample from Tank 102AW

\subsubsection{Site D: Uranium Foundry}

Site $D$ is a depleted uranium metal-working and foundry facility. Field spectra were obtained by taking a plastic scintillator spectrometer into actual production areas. Each beta spectrum was obtained by subtracting the photon portion of the beta-plus-gamma spectrum. To obtain the gamma-only spectra, beta shields of plastic, ranging in thickness from $60 \mathrm{mg} / \mathrm{cm}^{2}$ to $1000 \mathrm{mg} / \mathrm{cm}^{2}$ were placed over the detector. Because low-energy (less than $20 \mathrm{keV}$ ) photon fields and intense high-energy photon fields caused distortions in the subtracted beta spectra, it was necessary to characterize the photon fields where beta measurements were made.

In Figures 40 through 44 the beta spectra seen are very similar in shape to a typical uranium spectrum. However, the average energies derived from the spectra are slightly higher than the $800 \mathrm{keV}$ average energy expected for uranium. This apparently stems from two sources: 1) pulse pileup, and 2) the subtraction of distorted gamma spectra. The pulse pileup occurs at high count rates when two simultaneous pulses are summed to appear as one higher energy event. The distorted gamma spectra result when a thick plastic filter is placed on the face of the detector. Under broad-beam conditions, the number 


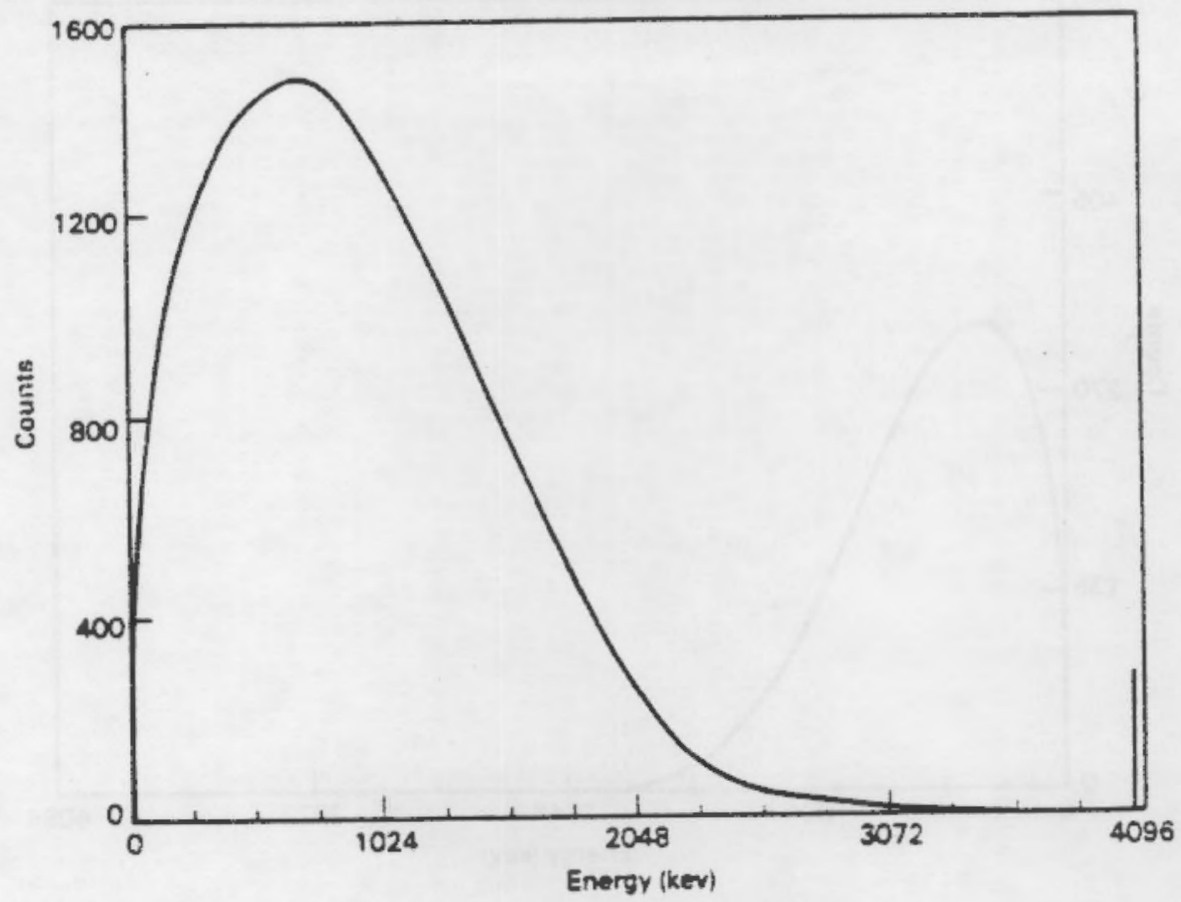

FIGURE 40. Beta Spectrum for the End Cut from a Uranium Billet

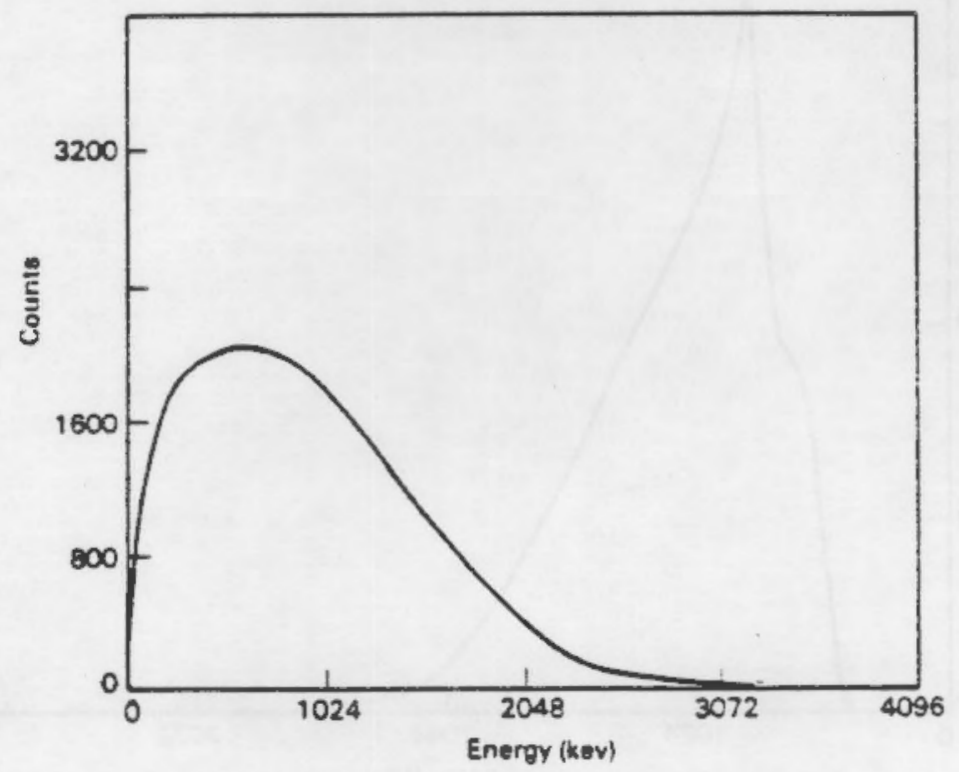

FIGURE 41. Beta Spectrum for the Top of a Uranium Electrode Pour 


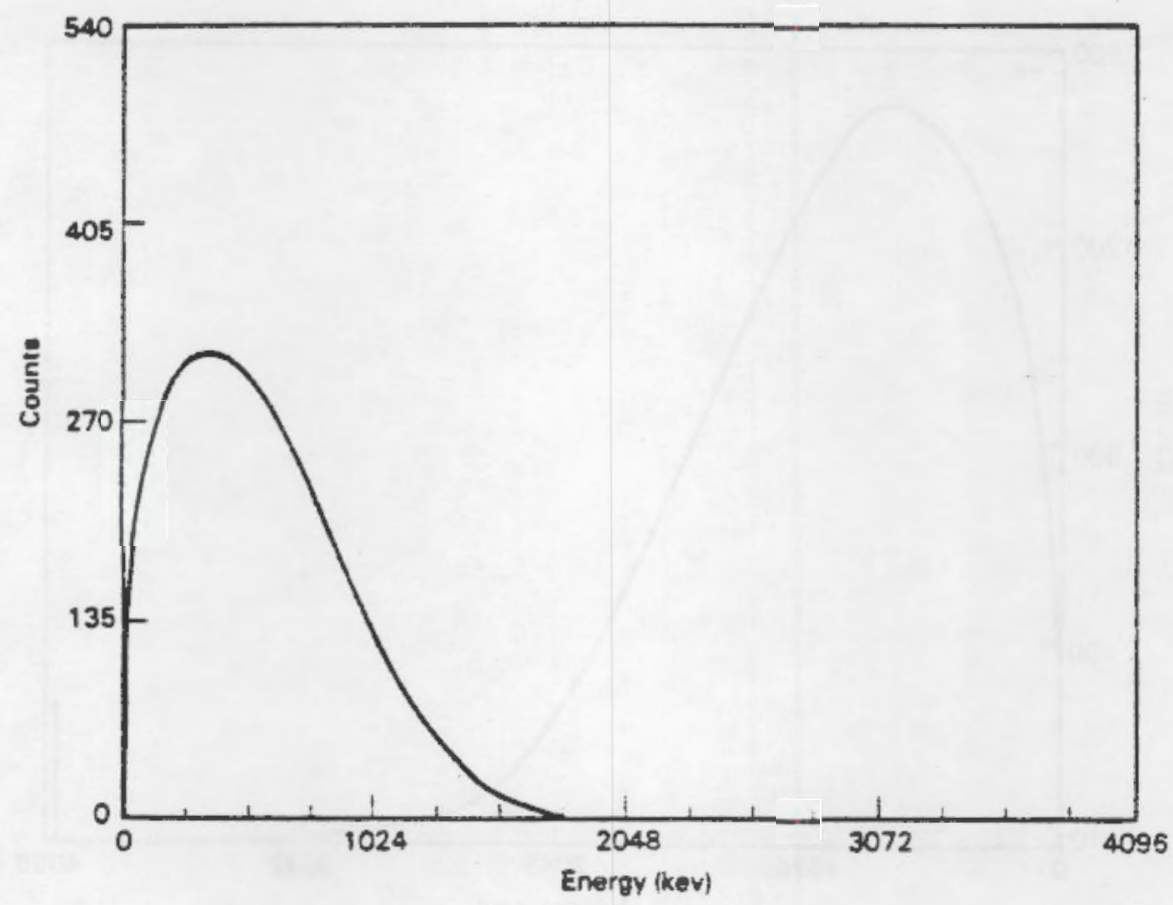

FIGURE 42. Beta Spectrum at $1 \mathrm{~m}$ from a Charge Makeup Crucible

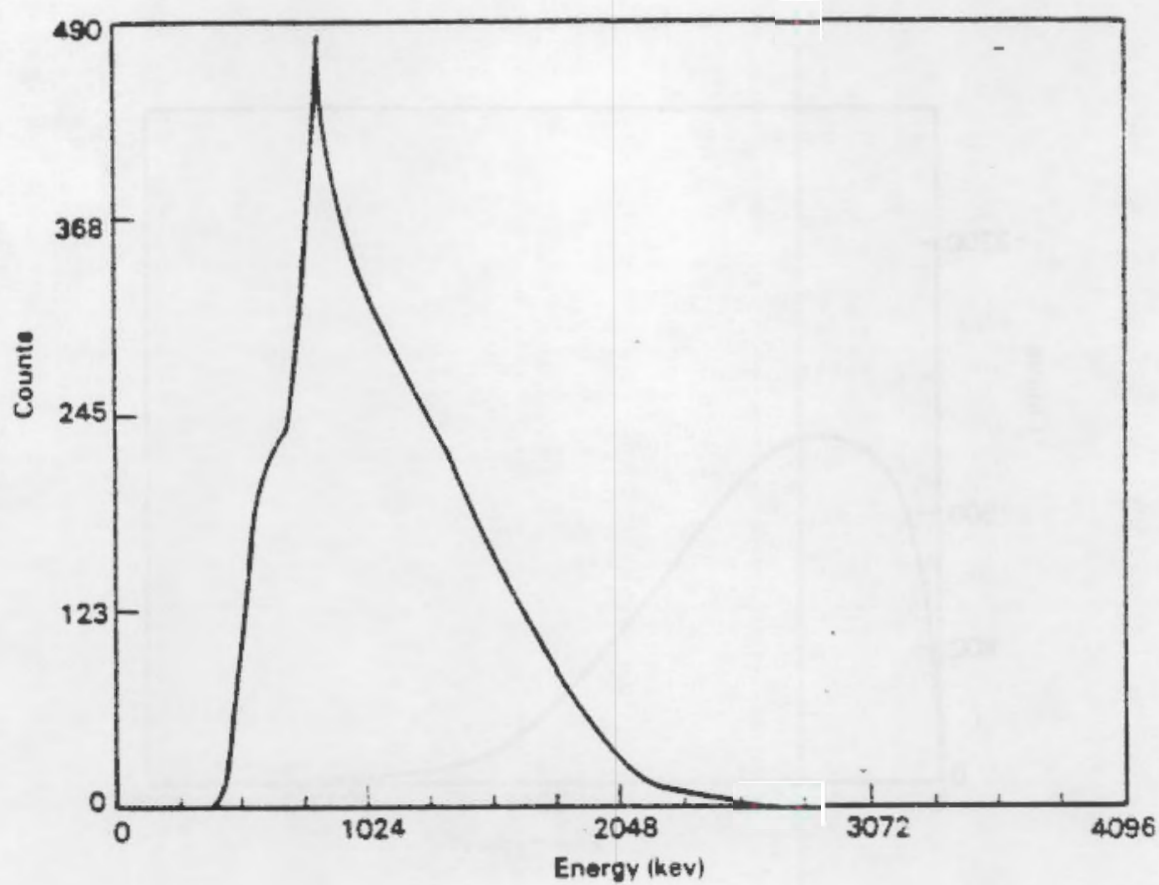

FIGURE 43. Beta Spectrum at $1.9 \mathrm{~cm}$ from a Charge Makeup Crucible 


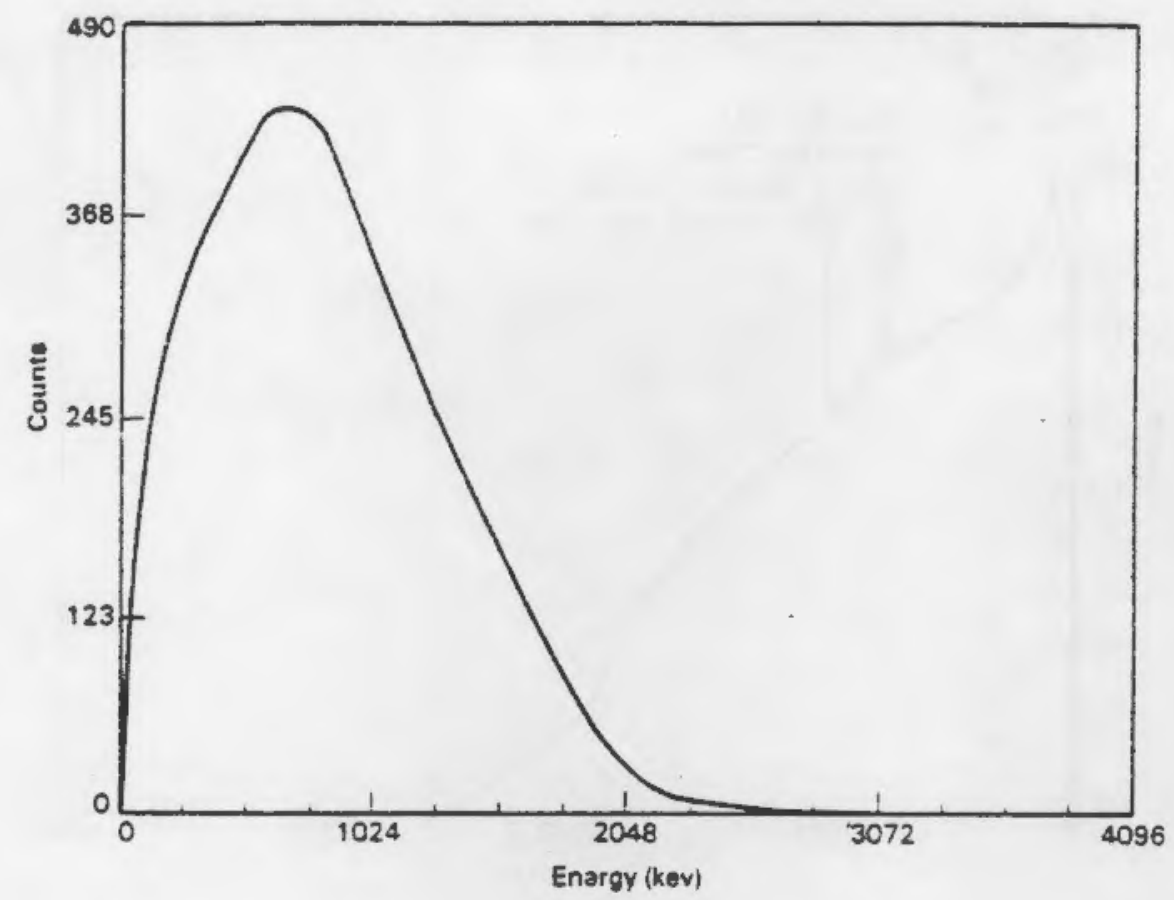

FIGURE 44. Corrected Beta Spectrum at $1.9 \mathrm{~cm}$ from a Charge Makeup Crucible

of electrons and secondary photons due to Compton scattering in the plastic filter plus the uncollided photons incident upon the detector can exceed the number of photons that would impact the detector in the absence of the plastic filter. Thus, there are too many counts in the gamma spectrum. When the subtraction is made, the remaining "beta" spectrum has too few counts. This effect is seen in Figure 42 , but Figure 43 is a more extreme example. If it were not for the effect described above, Figure 43 would look similar to Figure 44. Both the pulse pileup and photon spectra subtraction problems tend to raise the calculated average beta energies and lower the calculated dose. In most cases, the combined effect is no more than a few percent of the total. However, when the beta-to-gamma ratio is low, as in Figure 43 , the effect is more significant.

A gamma spectrometer was used to aid in the interpretation of the beta spectra. The spectra generated with this system are shown in Figures 45 through 48. Significant gamma peaks are seen at approximately $90 \mathrm{keV}$, $770 \mathrm{keV}$, and $1000 \mathrm{keV}$. 


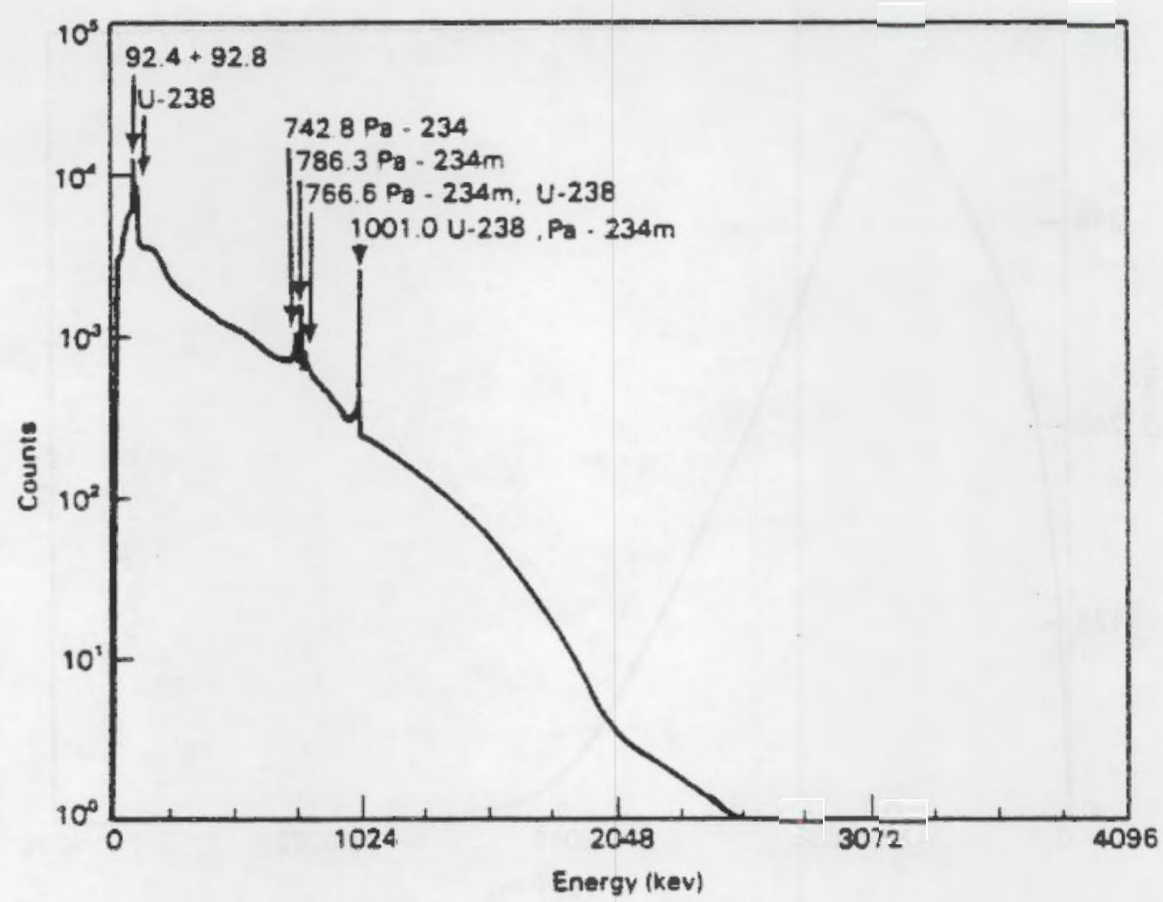

FIGURE 45. Germanium Gamma Spectrum for an End Cut from a Uranium Billet

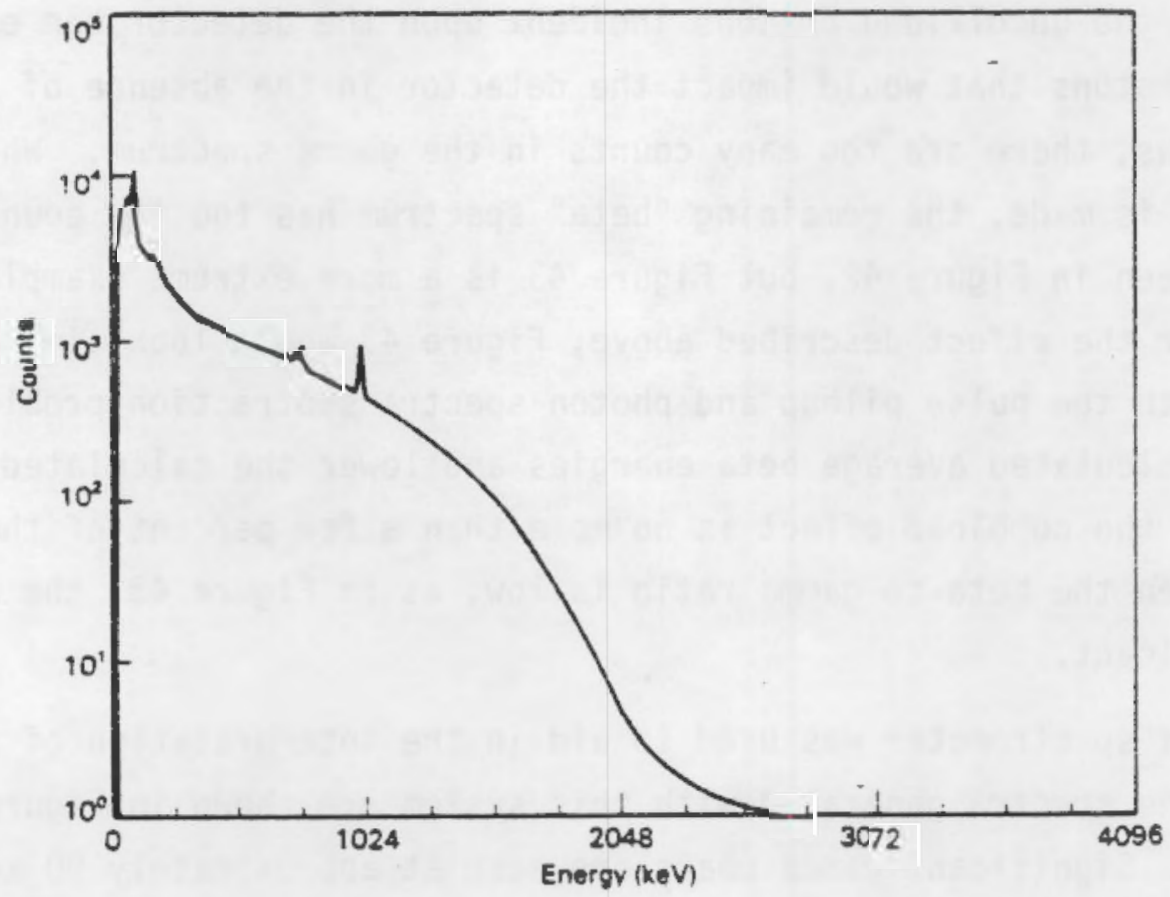

FIGURE 46. Germanium Gamma Spectrum for a Fresh Cast Electrode 


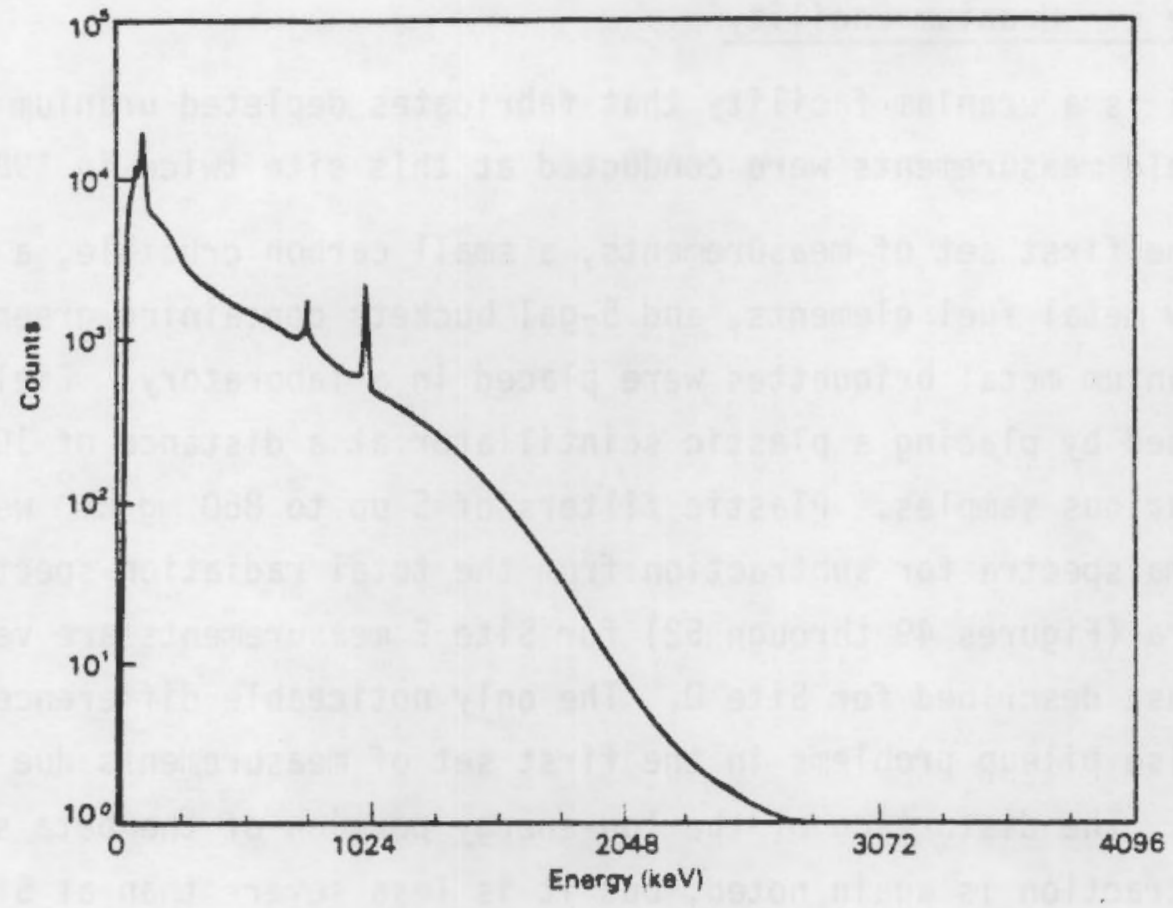

FIGURE 47. Germanium Gamma Spectrum for an Arc Melt Cast

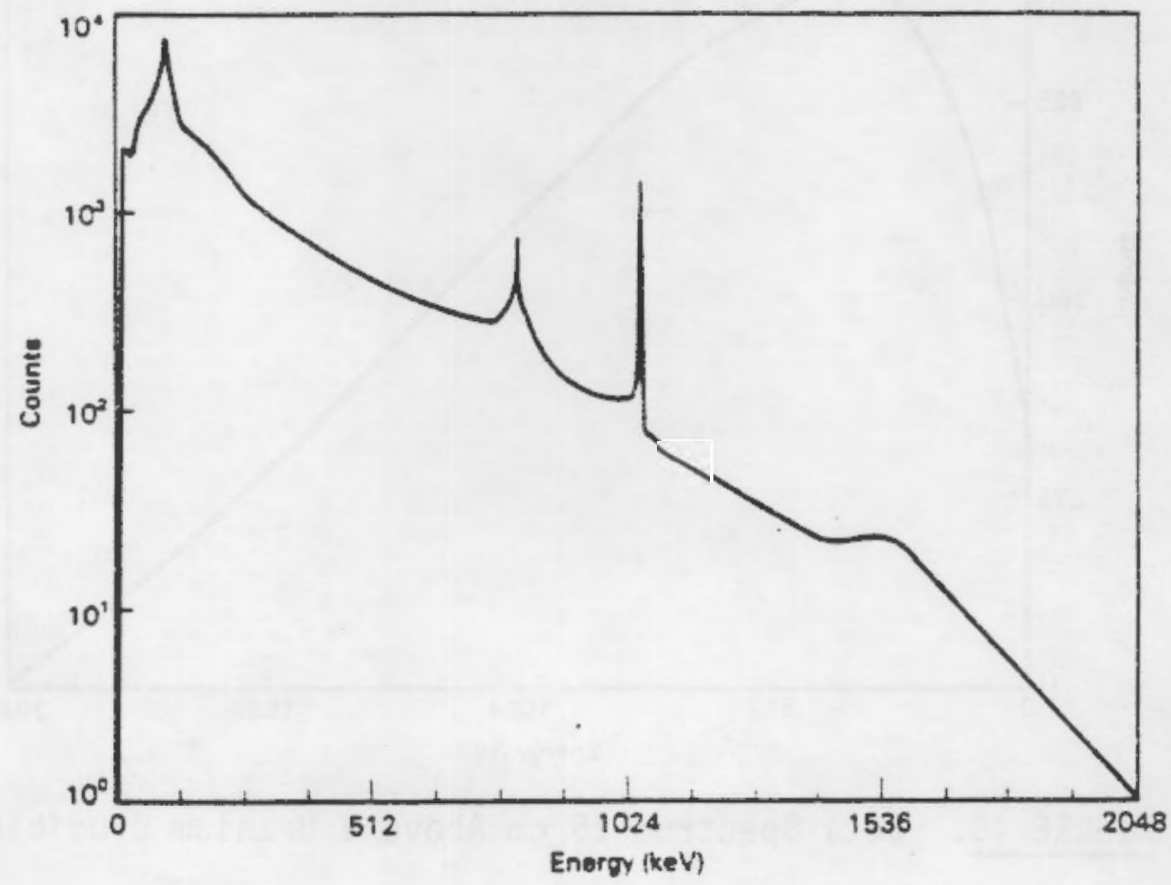

FIGURE 48. Germanium Gamma Spectrum for a Charge Makeup Crucible 


\subsubsection{Site E: Uranium Facility}

Site $E$ is a uranium facility that fabricates depleted uranium metal products. Field measurements were conducted at this site twice in 1985.

For the first set of measurements, a small carbon crucible, a pallet with hollow metal fuel elements, and 5-gal buckets containing green salt and pressed uranium metal briquettes were placed in a laboratory. Field spectra were obtained by placing a plastic scintillator at a distance of 10 to $25 \mathrm{~cm}$ from the various samples. Plastic filters of 5 up to $860 \mathrm{mg} / \mathrm{cm}^{2}$ were used to obtain gamma spectra for subtraction from the total radiation spectra. The beta spectra (Figures 49 through 52) for Site $E$ measurements are very similar to those just described for site $D$. The only noticeable difference is the lack of pulse pileup problems in the first set of measurements due to lower dose rates. The distortion of the low-energy portion of the beta spectra by photon subtraction is again noted, but it is less severe than at Site $D$.

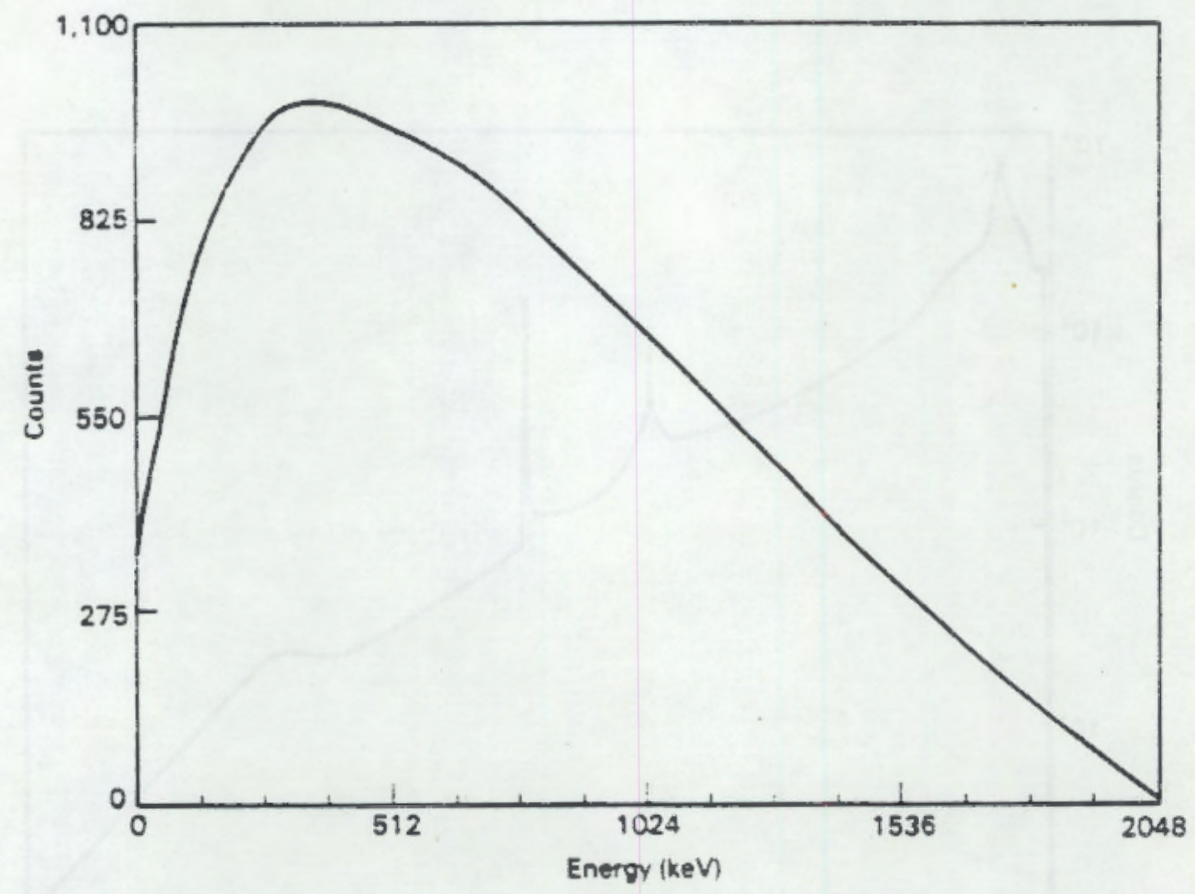

FIGURE 49. Beta Spectrum $15 \mathrm{~cm}$ Above a Uranium Crucible 


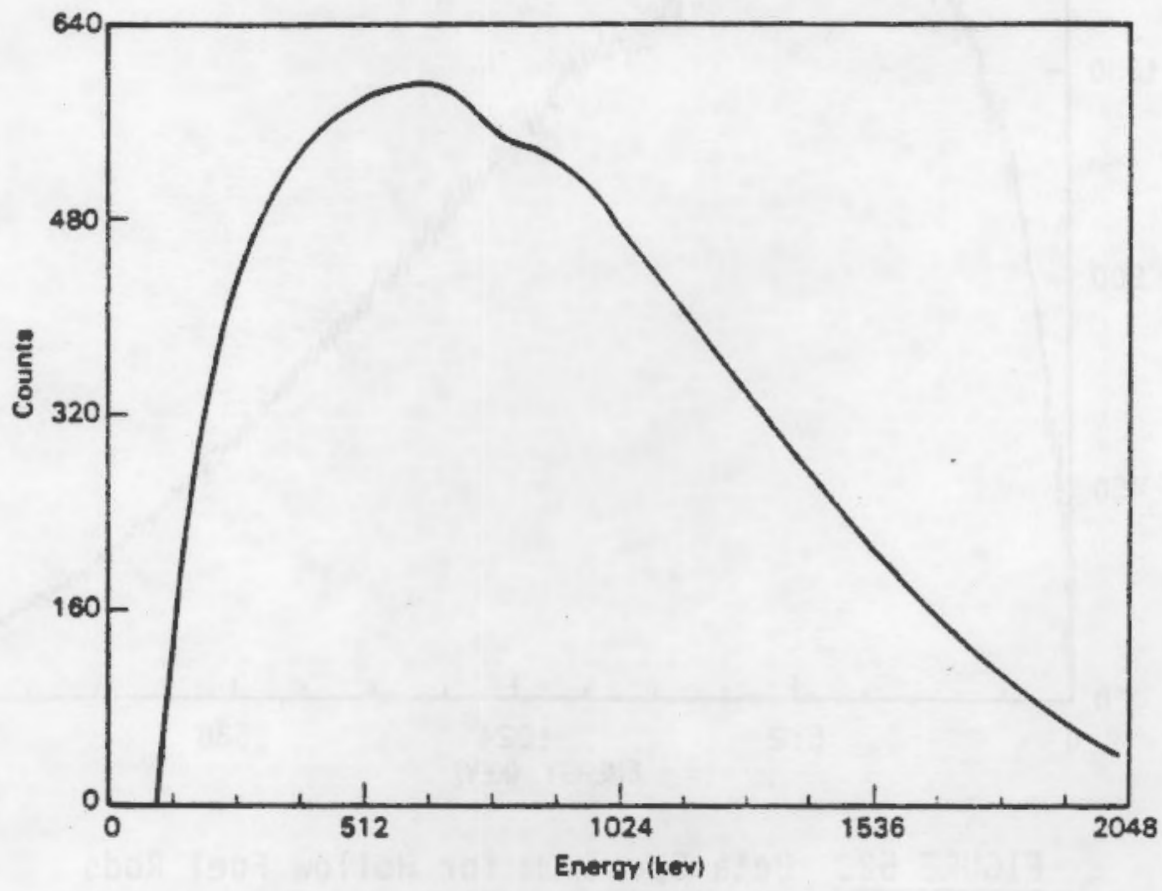

FIGURE 50. Beta Spectrum for Green Salt

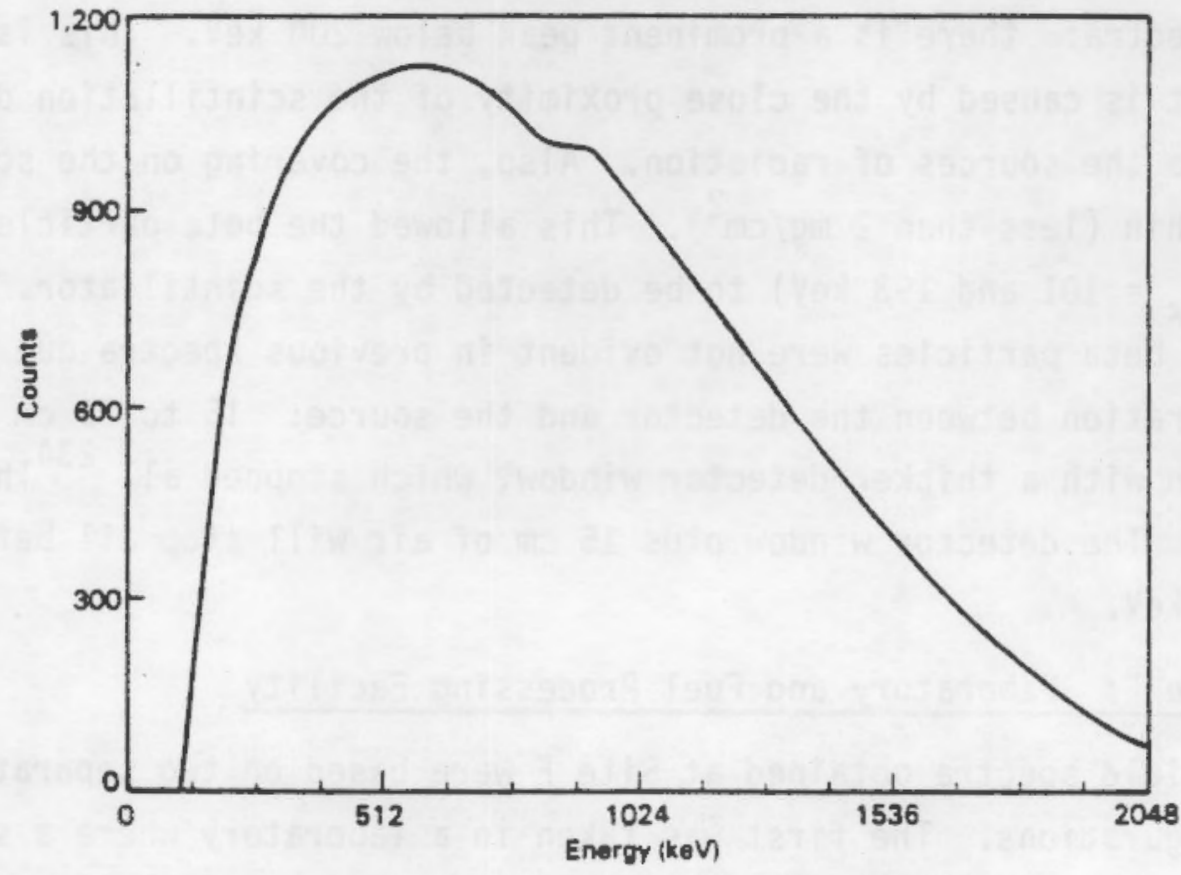

FIGURE 51. Beta Spectrum for Briquettes 


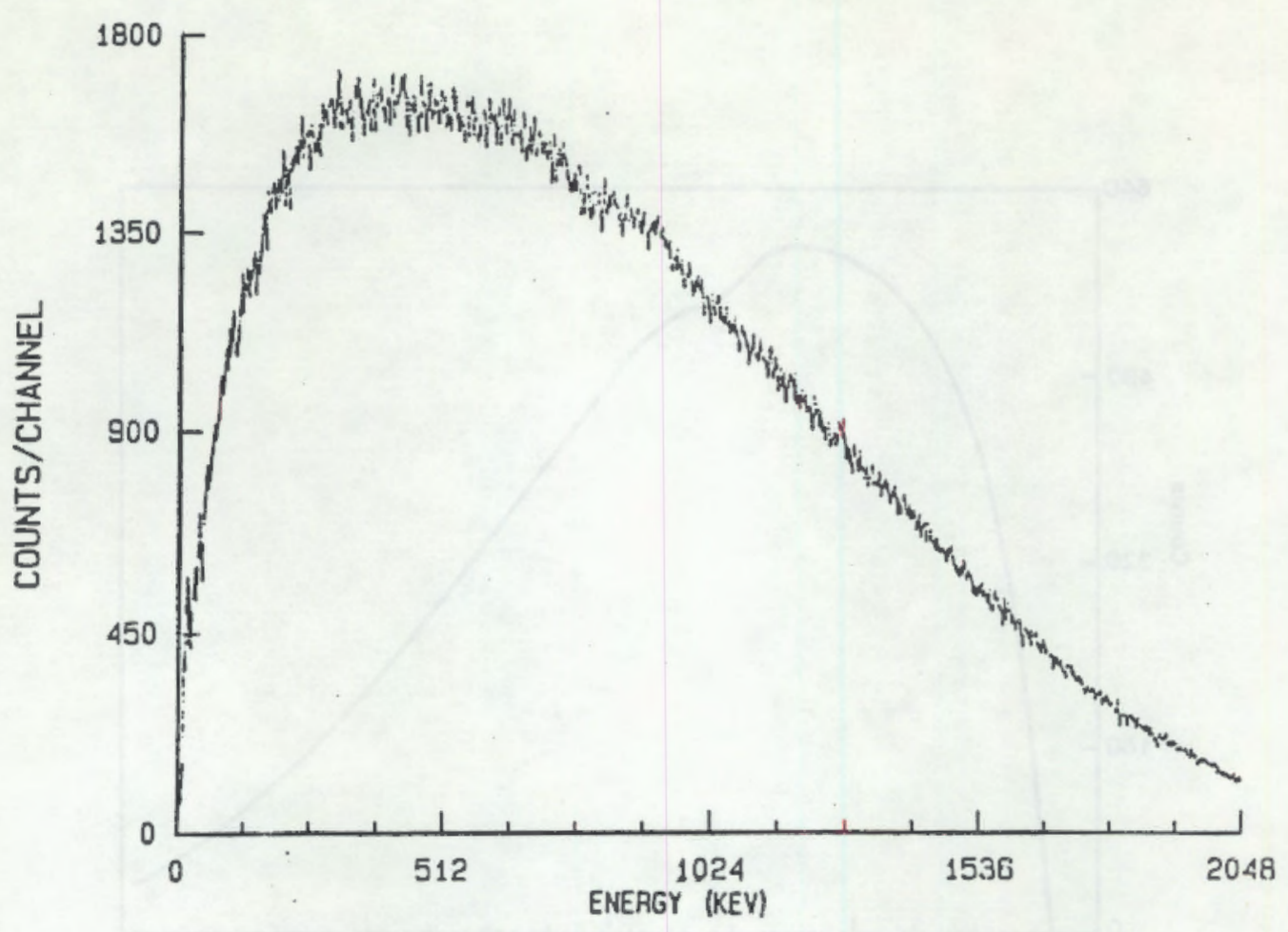

FIGURE 52. Beta Spectrum for Hollow Fuel Rods

During a second visit to Site $E$, beta spectra of a crucible, a contaminated glove, a fuel element, and a smear from a uranium ingot were obtained (Figures 53 through 58). These spectra are noticeably different from the earlier spectra: there is a prominent peak below $200 \mathrm{keV}$. This is a beta peak and it is caused by the close proximity of the scintillation detector $(0.6 \mathrm{~cm})$ to the sources of radiation. Also, the covering on the scintillator was very thin (less than $2 \mathrm{mg} / \mathrm{cm}^{2}$ ). This allowed the beta particles from ${ }^{234} \mathrm{Th}\left(E_{\max }=101\right.$ and $\left.193 \mathrm{keV}\right)$ to be detected by the scintillator. These low-energy beta particles were not evident in previous spectra due to the usual separation between the detector and the source: 15 to $25 \mathrm{~cm}$ of air, in combination with a thicker detector window, which stopped a $11{ }^{234}$ Th beta particles. The detector window plus $15 \mathrm{~cm}$ of air will stop all beta particles below $130 \mathrm{keV}$.

\subsubsection{Site F: Laboratory and Fuel Processing Facility}

The field spectra obtained at Site $F$ were based on two separate measurement configurations. The first was taken in a laboratory where a soil sample containing fission products had been placed. The second set of measurements was taken at an opening designed for sampling in a spent fuel processing facility. 


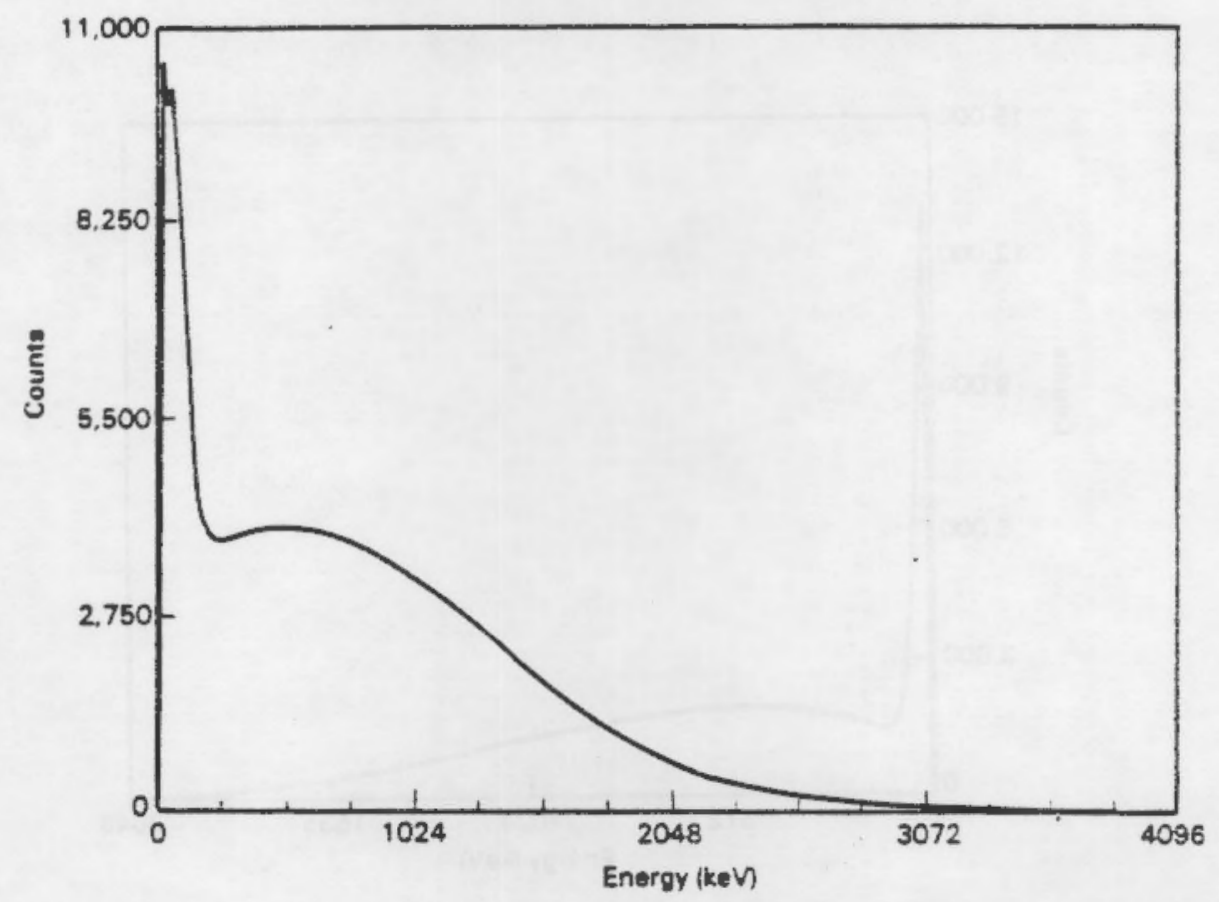

FIGURE 53. Beta Spectrum for a Graphite Crucible at $0.6 \mathrm{~cm}$

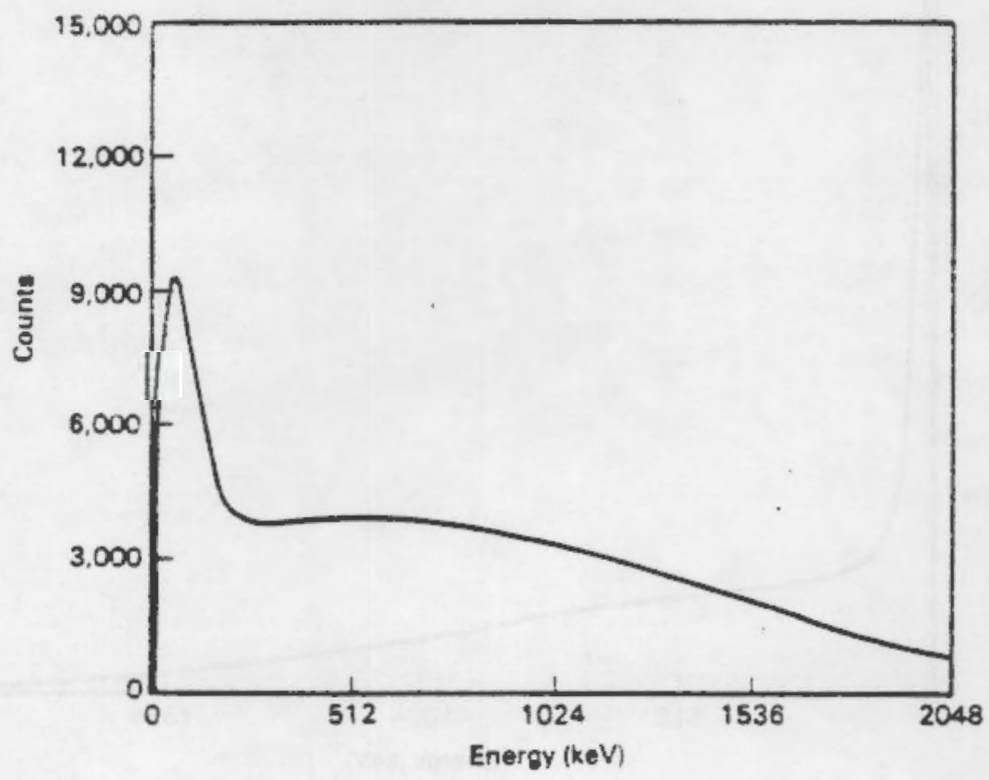

FIGURE 54. Beta Spectrum for the Outside of a Used Glove 


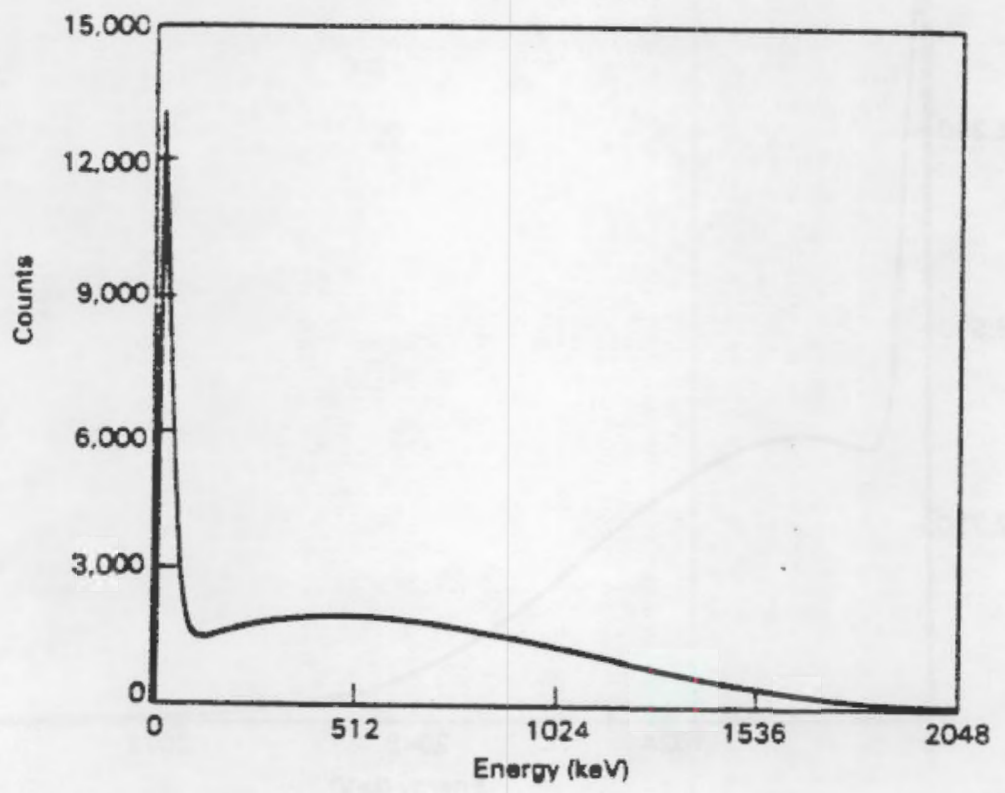

FIGURE 55. Beta Spectrum for the Inside of a Used Glove

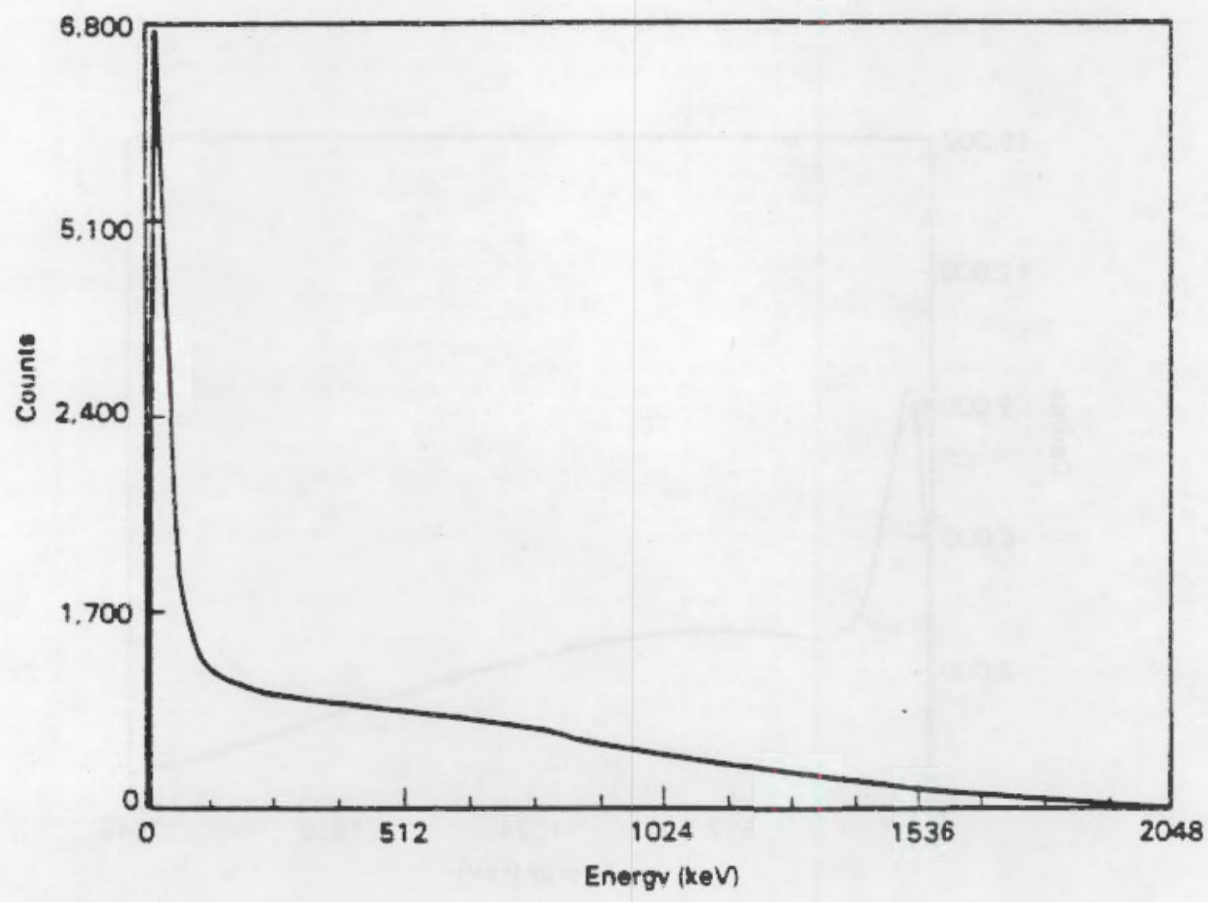

FIGURE 56. Beta Spectrum for a Briquette at $0.6 \mathrm{~cm}$ from the Detector 


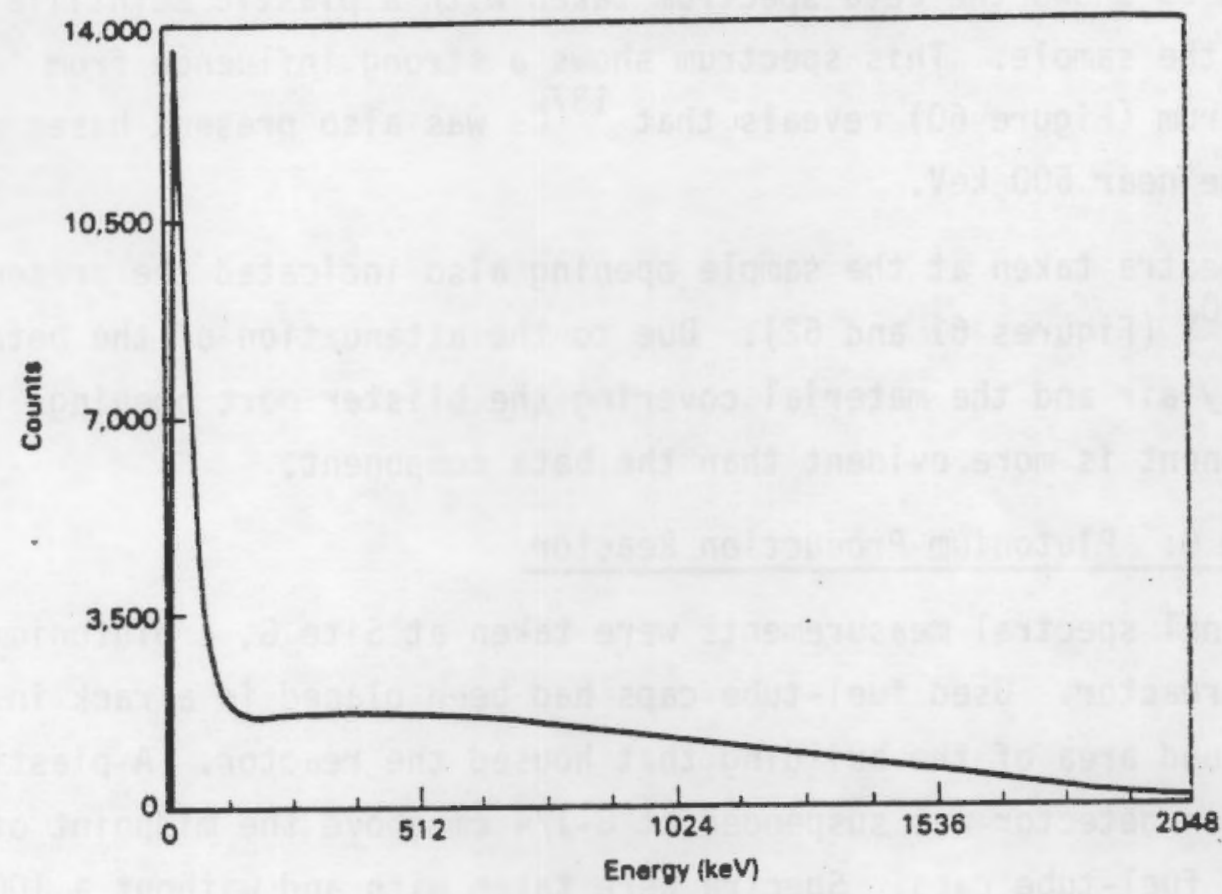

FIGURE 57. Beta Spectrum for an Ingot Smear

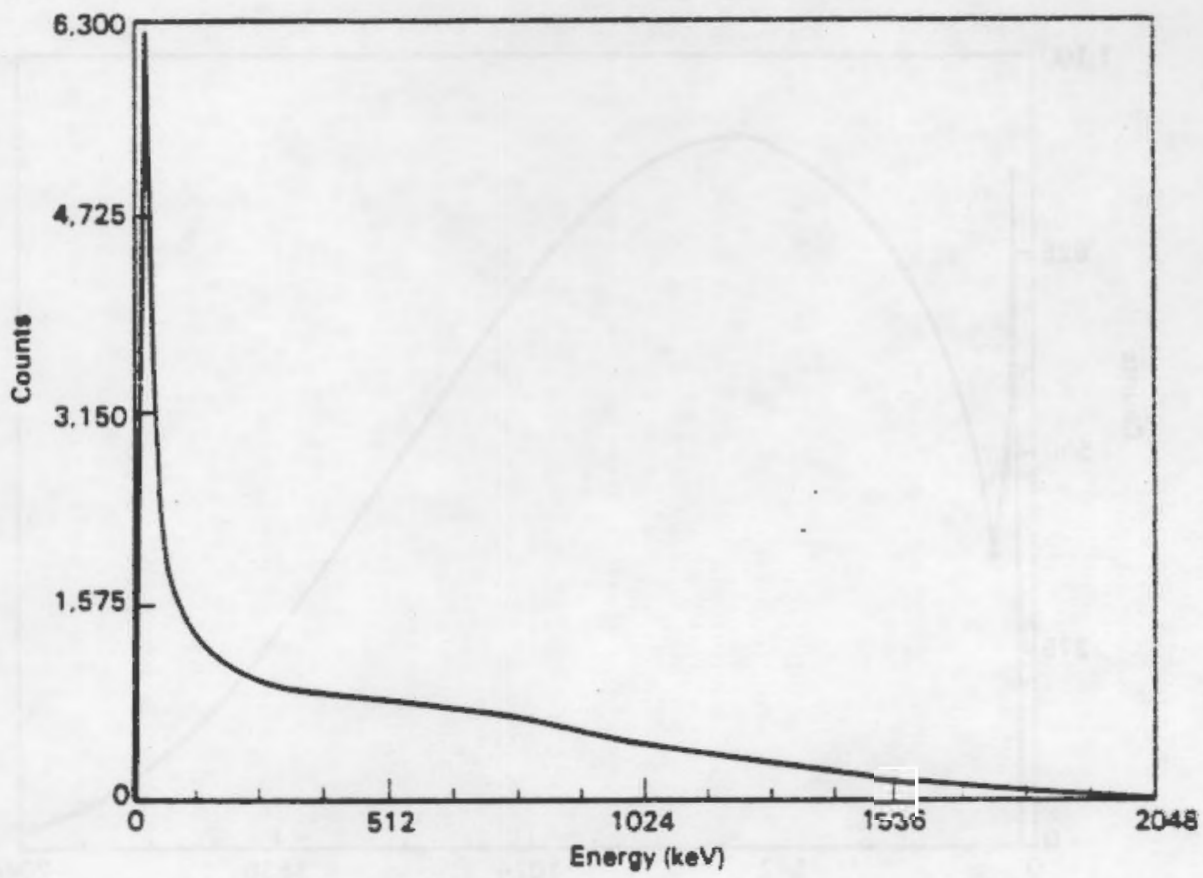

FIGURE 58. Beta Spectrum for a Fuel Element at $0.6 \mathrm{~cm}$ from the Detector 
Figure 59 shows the beta spectrum taken with a plastic scintillator at $30 \mathrm{~cm}$ from the sample. This spectrum shows a strong influence from $90_{Y}$. The gamma spectrum (Figure 60 ) reveals that ${ }^{137} \mathrm{Cs}$ was also present based on the Compton edge near $500 \mathrm{keV}$.

The spectra taken at the sample opening also indicated the presence of ${ }^{137} \mathrm{Cs}$ and ${ }^{90} Y$ (Figures 61 and 62 ). Due to the attenuation of the beta particles by air and the material covering the blister port opening, the ${ }^{137} \mathrm{Cs}$ gamma component is more evident than the beta component.

\subsubsection{Site G: Plutonium Production Reactor}

The final spectral measurements were taken at Site $G$, a plutonium production reactor. Used fuel-tube caps had been placed in a rack in a low-background area of the building that housed the reactor. A plastic scintillation detector was suspended at $8-1 / 4 \mathrm{~cm}$ above the midpoint of an array of 21 fuel-tube caps. Spectra were taken with and without a $1000-\mathrm{mg} / \mathrm{cm}^{2}$ plastic cover on the detector. The spectra, shown in Figures 64 and 65 , indicate that the radiation field was largely due to ${ }^{60}$ Co contamination.

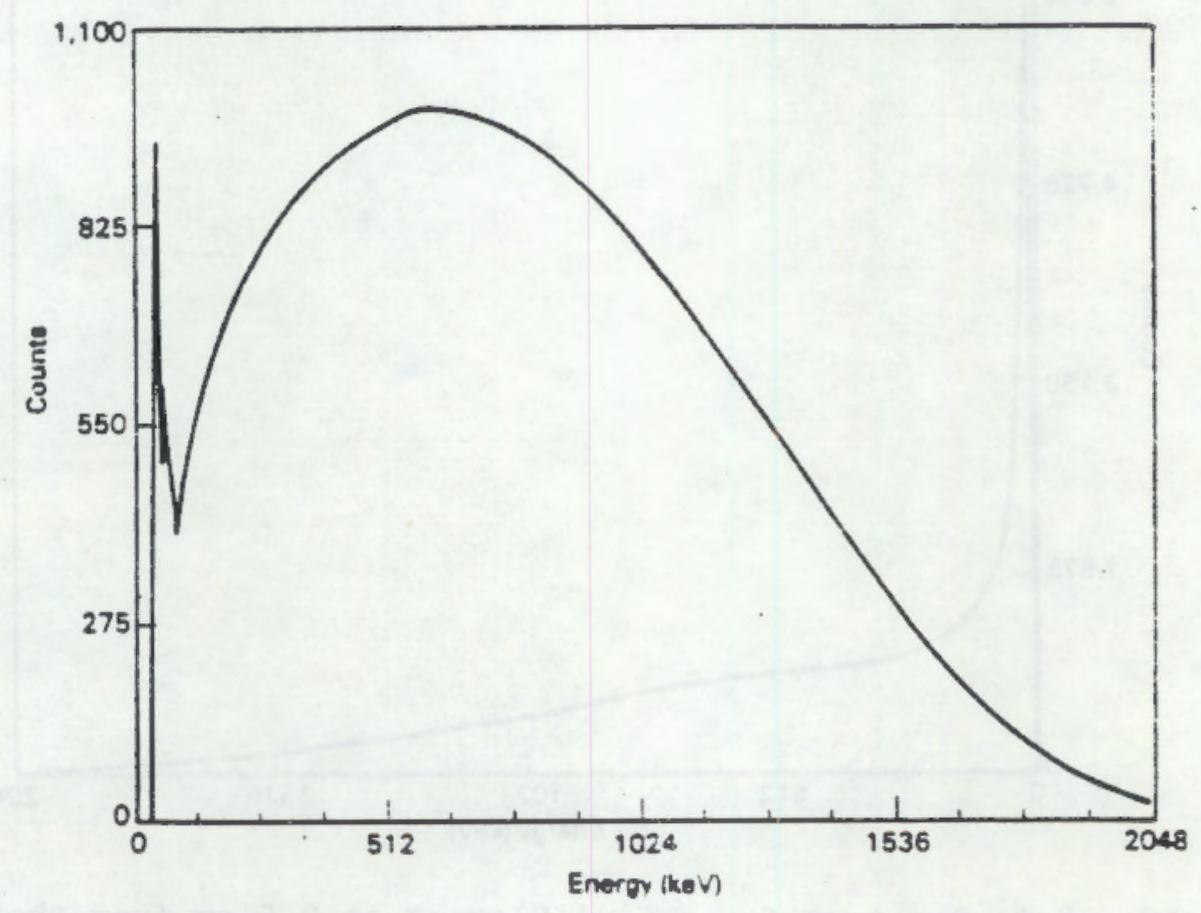

FIGURE 59. Beta Spectrum for a Contaminated Soil Sample 


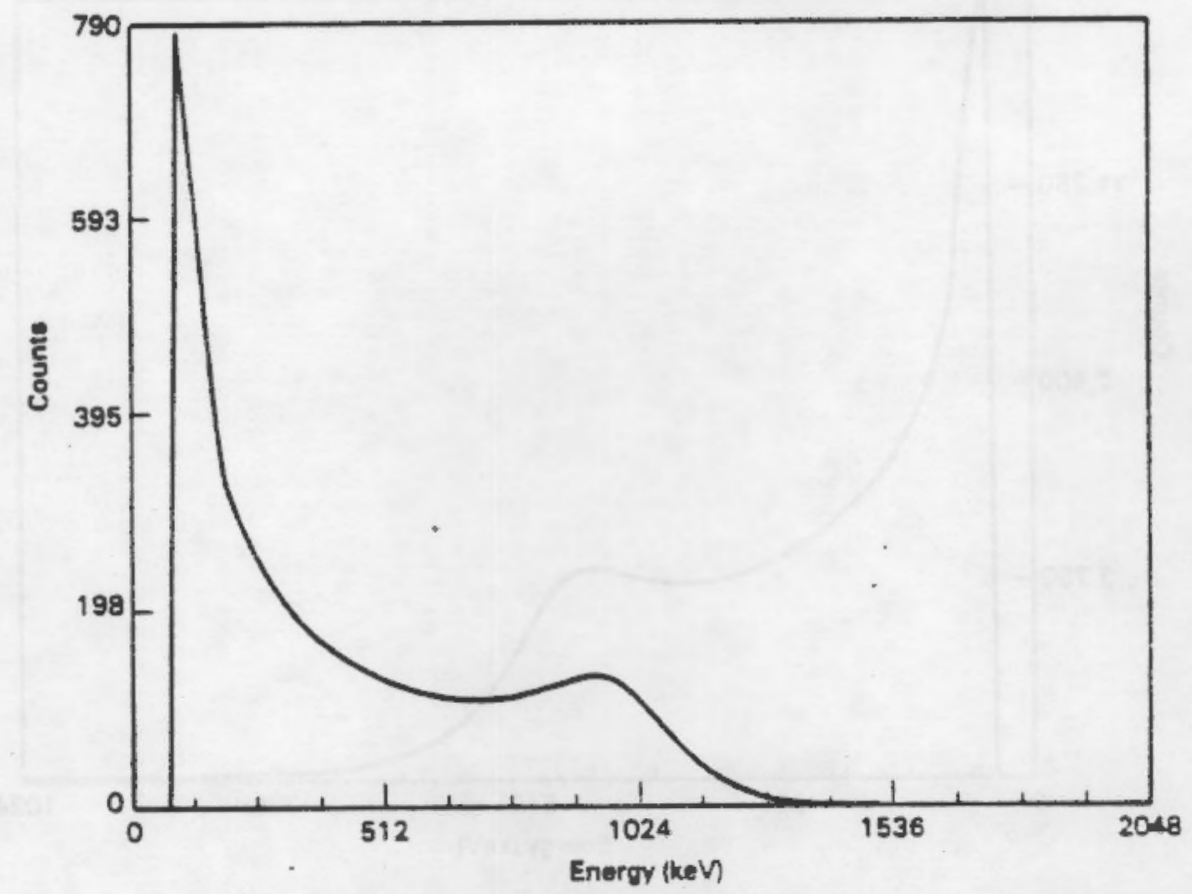

FIGURE 60. Gamma Spectrum for a Contaminated Soil Sample

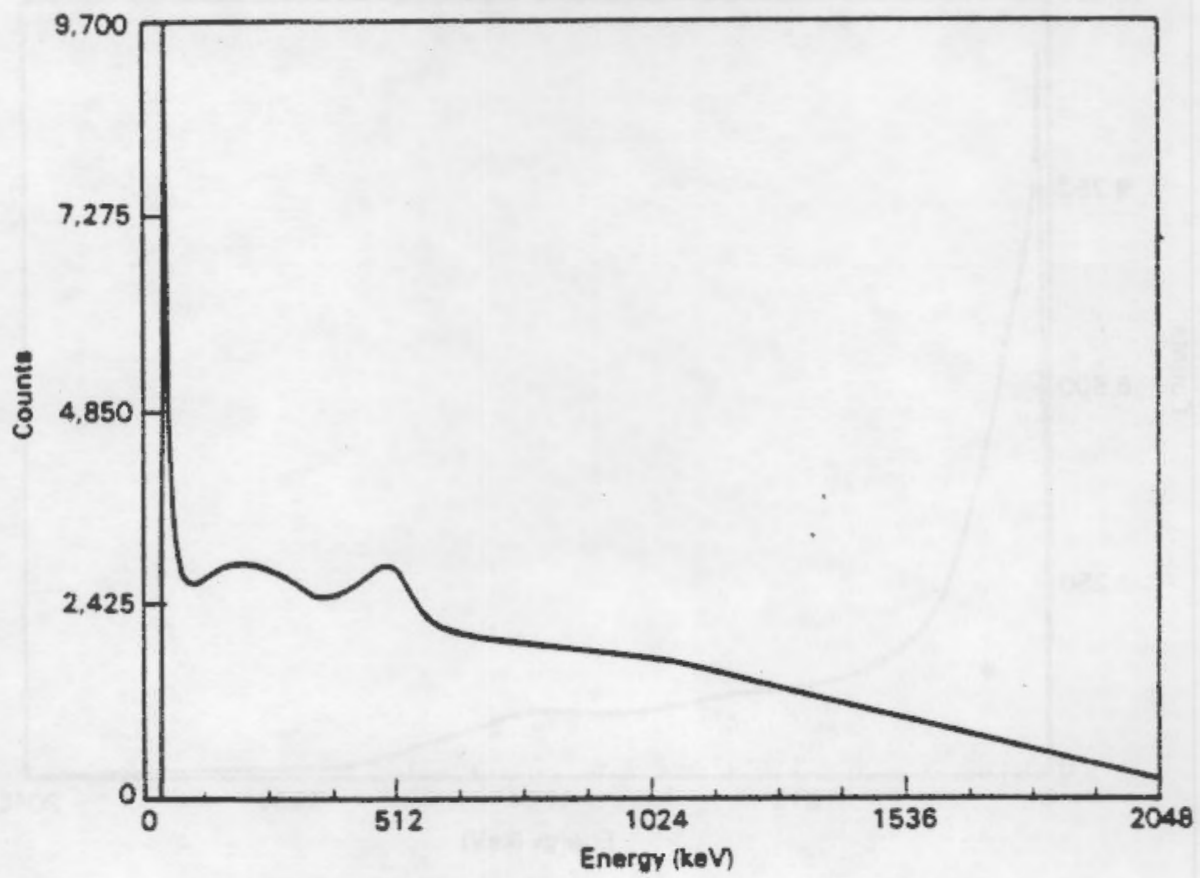

FIGURE 61 . Beta Spectrum at $60 \mathrm{~cm}$ from a Blister Port 


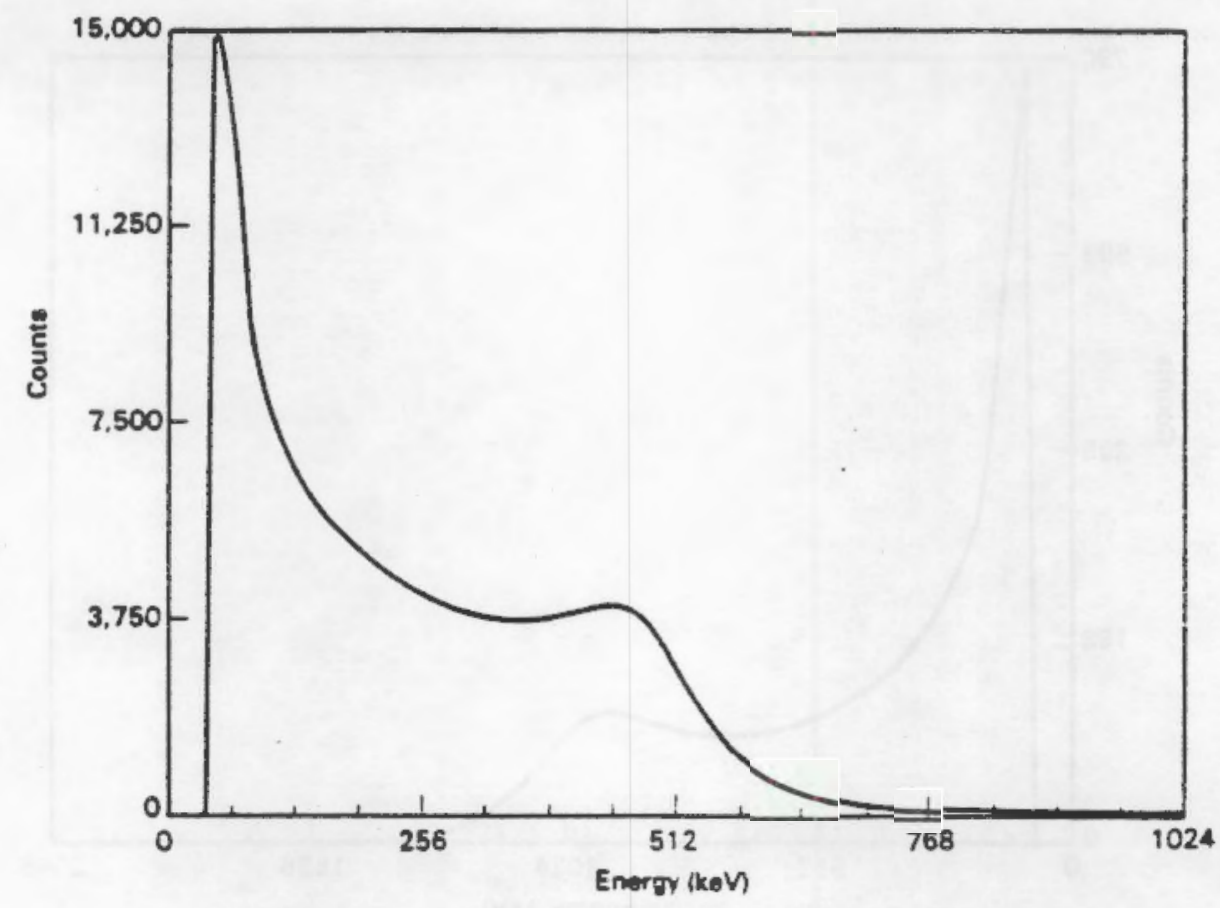

FIGURE 62. Gamma Spectrum at $60 \mathrm{~cm}$ from a Blister Port

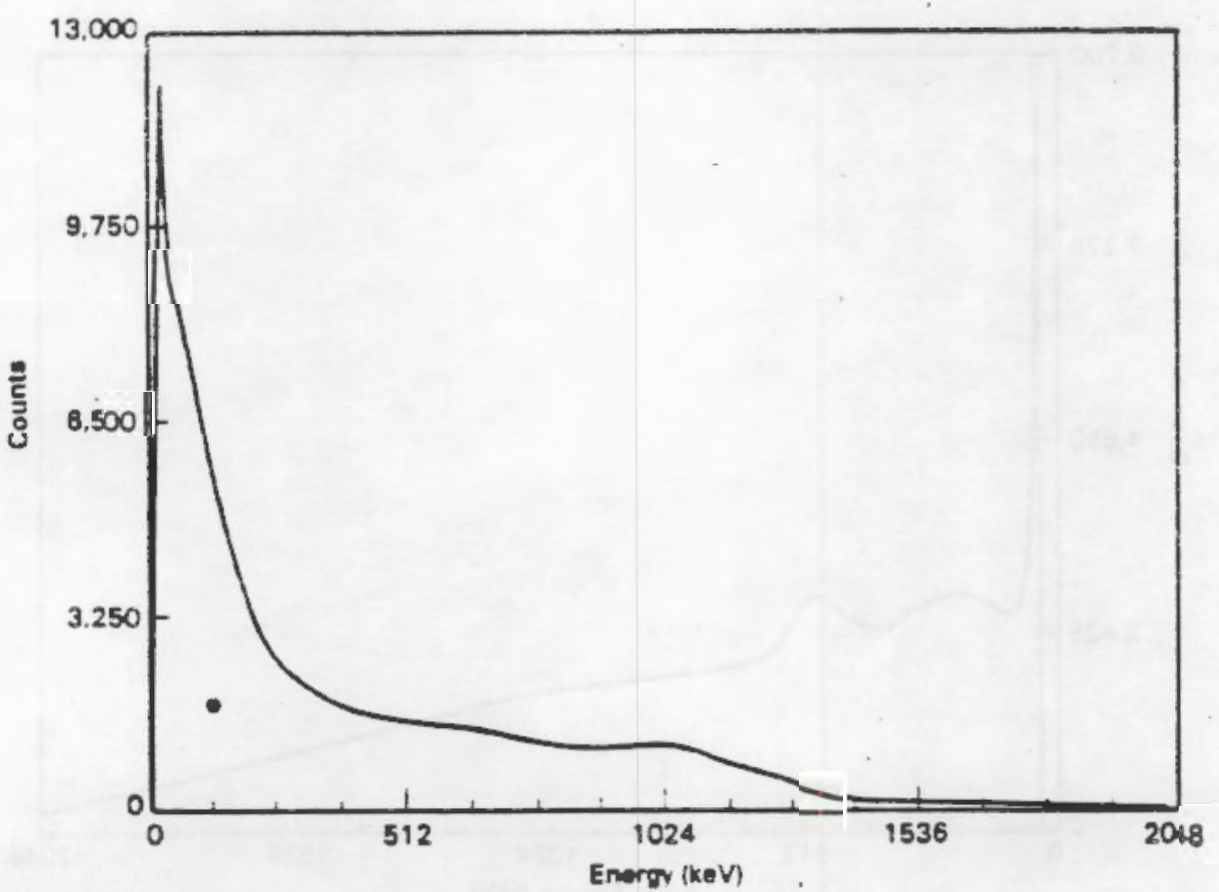

FIGURE 63. Beta-Plus-Gamma Spectrum for Fuel-Tube Caps 


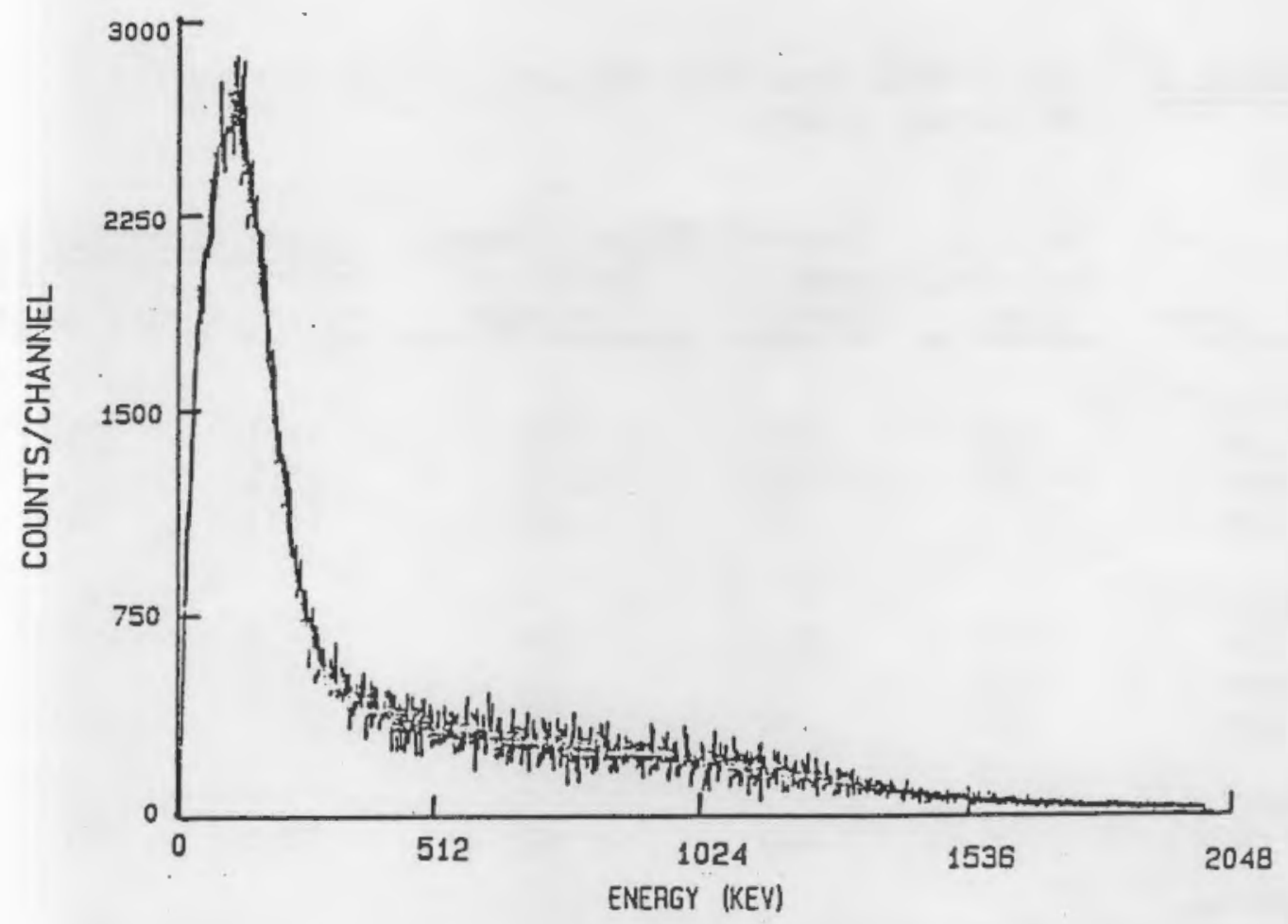

FIGURE 64. Beta Spectrum for Fuel-Tube Caps

\subsection{DOSE RATE MEASUREMENTS}

\subsubsection{Site A: Separation Facility}

At Site $A$, beta dose rates and doses were obtained from the spectrometer, survey meter, and eight-element dosimeter for each measurement location except that the waste sample spectrum for the second visit did not provide a useful beta dose; any beta dose was completely masked by variations in the gamma component. The results are shown in Table 8 . There is good agreement between the dose rates derived from the three devices for the first process sample, especially at 60 and $90 \mathrm{~cm}$. Because of the hard beta spectra produced by encasing the sources in glass bottles, the spectral doses were not corrected for low-energy backscatter (Rathbun et al. 1984) and a small correction factor (1.2) (Table 5) was used for the survey meter. However, a correction factor of 1.33 (Section 3.1.4) was used for the spectral dose when the process sample data from the second visit were analyzed. This was based on the very low attenuation of beta particles provided by the gauze pad that contained the sample. For the same reason, a correction factor of 2.5 (Section 3.4 ) was 
TABLE 8. Site A Beta Dose Rates Measured with Spectrometers and Survey Meters

\begin{tabular}{|c|c|c|c|c|c|}
\hline Radiation Source & $\begin{array}{l}\text { Spectral } \\
\text { Analysis, } \\
\mathrm{mrad} / \mathrm{h} \\
\end{array}$ & $\begin{array}{c}\text { Survey } \\
\text { Meter A, } \\
\mathrm{mrad} / \mathrm{h} \\
\end{array}$ & $\begin{array}{c}\text { PNL } \\
\text { Eight-Element, } \\
\text { Dosimeter } \\
\mathrm{mrad} / \mathrm{h} \\
\end{array}$ & $\begin{array}{l}\text { Beta: } \\
\text { Survey } \\
\text { Meter }\end{array}$ & $\begin{array}{l}\text { Gamma Ratios } \\
\text { Eight-ETement } \\
\text { Dosimeter }\end{array}$ \\
\hline $\begin{array}{l}\text { Process Sample (a) } \\
\text { at } 30 \mathrm{~cm} \\
\text { at } 60 \mathrm{~cm} \\
\text { at } 90 \mathrm{~cm}\end{array}$ & $\begin{array}{r}610 \\
130 \\
50\end{array}$ & $\begin{array}{r}840 \\
130 \\
40\end{array}$ & $\begin{array}{r}730 \\
120 \\
50\end{array}$ & $\begin{array}{l}34: 1 \\
22: 1 \\
13: 1\end{array}$ & $\begin{array}{l}38: 1 \\
21: 1 \\
23: 1\end{array}$ \\
\hline $\begin{array}{l}\text { Waste Sample } \\
\text { at } 30 \mathrm{~cm} \\
\text { at } 60 \mathrm{~cm} \\
\text { at } 90 \mathrm{~cm}\end{array}$ & $\begin{array}{r}270 \\
100 \\
30\end{array}$ & $\begin{array}{r}360 \\
120 \\
40\end{array}$ & $\begin{array}{r}110 \\
50 \\
20\end{array}$ & $\begin{array}{l}12: 1 \\
24: 1 \\
13: 1\end{array}$ & $\begin{array}{r}11: 1 \\
13: 1 \\
4: 1\end{array}$ \\
\hline $\begin{array}{c}\text { Process Sample } e^{(b)} \\
\text { at } 30 \mathrm{~cm}\end{array}$ & 360 & 440 & 580 & $8: 1$ & $120: 1$ \\
\hline
\end{tabular}

(a) Samples analyzed during first trip. Samples were in glass bottles. (b) Sample analyzed during second trip. Sample was on gauze pad.

used for the survey meter. Even with these corrections, the results from the survey meter and spectral measurements were low during the second trip relative to results from the eight-element dosimeter.

The beta doses shown for the first process sample decrease with distance as expected based on an inverse distance squared relationship (plus air attenuation). The relationship of dose versus distance for the waste sample in Table 8 is not so straightforward. Although the doses at $90 \mathrm{~cm}$ versus those at $60 \mathrm{~cm}$ follow the expected inverse distance squared (plus attenuation) relationship, the doses at $30 \mathrm{~cm}$ appear to be too low relative to those at 60 and $90 \mathrm{~cm}$. The same correction factors used for the first process sample were used for the waste sample, based on a similar configuration. This caused the spectral doses to be approximately 75 to $85 \%$ as high as the survey meter doses. The eight-element dosimeter doses were only 30 to $50 \%$ of the survey meter doses. It is not clear why this should be the case; it does not follow the trend of the process samples. 
Gamma doses were also determined for each sample with a survey meter and an eight-element dosimeter. These gamma doses generally follow an inverse distance squared relationship with distance except for the eight-element dosimeter with the waste sample. In the latter case the gamma doses at 30 and $60 \mathrm{~cm}$ appear to be too low.

Beta-to-gamma ratios were also determined at a distance of $30 \mathrm{~cm}$ with the survey meter and eight-element dosimeter. These results are listed in Table 8 . All the beta-to-gamma ratios are high, but the eight-element dosimeter beta-to-gamma ratio is much higher than that of the survey meter during the second visit.

\subsubsection{Site B: Fuel Fabrication Facility}

The results of measurements with the three survey meters, the scintillation detector, and the multielement dosimeters are shown in Tables 9 and 10. The multielement dosimeters and scintillation detector may be assumed to provide good estimates $( \pm 50 \%)$ of the contact beta dose rates for the fuel elements. Al though contact beta readings are also listed for the survey meters there is no direct correspondence between the contact survey meter readings and the actual contact dose. Although the window of the chamber is in contact with the source, the sensitive volume of the chamber is separated from the source. Meter readings represent the average ionization throughout the sensitive volume. Hence, the survey meter readings underestimate the beta dose in close proximity to the source, unless a correction factor is applied. Based on previous experience at PNL (Table 7), a correction factor of 5.3 was used with the $7-\mathrm{cm}-\mathrm{dia}$ fuel element readings to determine contact doses with the survey meters. Even with this adjustment, the beta contact doses and total doses measured with the survey meters were low relative to the corres-

ponding values for the multielement detectors. The readings for the $208-\mathrm{cm}^{3}$ CP were especially low, but they were still within $50 \%$ of the multielement contact doses. A factor of 1.2 was used for all distances other than contact, based on the same rationale discussed for Site $A$. It is apparent from the preceding tables that the whole body dose rate in the vicinity of a fuel element (not in contact with it) is typically no more than $1 \mathrm{mrad} / \mathrm{h}$. This is borne out by data from other multielement dosimeters placed in various work 
TABLE 9. Site B Dose Rates from a $0.95 \%$-Enriched Fuet Element, mrad/h (a)

\begin{tabular}{|c|c|c|c|c|c|}
\hline instrument & \multirow{2}{*}{$\begin{array}{c}\text { Open } \\
\text { Window } \\
\\
2.5 \\
0.8 \\
0.5 \\
0.3\end{array}$} & \multirow{2}{*}{$\begin{array}{l}\text { Closed } \\
\text { Hindow } \\
1.9 \\
0.5 \\
0.3 \\
0.2\end{array}$} & \multirow{2}{*}{$\begin{array}{c}\text { Gamma } \\
1.9 \\
0.5 \\
0.3 \\
0.2\end{array}$} & \multirow{2}{*}{$\begin{array}{l}\text { Beta } \\
3.2 \\
0.4 \\
0.2 \\
0.1\end{array}$} & \multirow{2}{*}{$\begin{array}{c}\text { Total } \\
5.1 \\
0.9 \\
0.5 \\
0.3\end{array}$} \\
\hline $\begin{array}{l}\text { Ion Chamber "A" Contact } \\
15 \mathrm{~cm} \\
30 \mathrm{~cm} \\
60 \mathrm{~cm}\end{array}$ & & & & & \\
\hline $\begin{array}{l}\mathrm{CP} " \mathrm{~B}^{\prime \prime}\left(208 \mathrm{~cm}^{3}\right) \text { Contact } \\
15 \mathrm{~cm} \\
30 \mathrm{~cm} \\
60 \mathrm{~cm}\end{array}$ & $\begin{array}{l}2.1 \\
0.7 \\
0.45 \\
0.3\end{array}$ & $\begin{array}{l}1.6 \\
0.5 \\
0.3 \\
0.25\end{array}$ & $\begin{array}{l}1.6 \\
0.5 \\
0.3 \\
0.25\end{array}$ & $\begin{array}{l}2.6 \\
0.2 \\
0.2 \\
0.1\end{array}$ & $\begin{array}{l}4.2 \\
0.7 \\
0.5 \\
0.35\end{array}$ \\
\hline $\begin{array}{l}\left.C P \text { "C" (463 } \mathrm{cm}^{3}\right) \text { Contact } \\
15 \mathrm{~cm} \\
30 \mathrm{~cm} \\
60 \mathrm{~cm}\end{array}$ & $\begin{array}{l}2.9 \\
1.0 \\
0.55 \\
0.35\end{array}$ & $\begin{array}{l}1.9 \\
0.85 \\
0.5 \\
0.3\end{array}$ & $\begin{array}{l}1.9 \\
0.85 \\
0.5 \\
0.3\end{array}$ & $\begin{array}{l}5.3 \\
0.2 \\
0.1 \\
0.1\end{array}$ & $\begin{array}{l}7.2 \\
1.0 \\
0.6 \\
0.4\end{array}$ \\
\hline Plastic Scintillator (Eve & $50 \mathrm{keV})$ & & & & 3.6 \\
\hline $\begin{array}{l}\text { Multielement Dosimeter } \\
\text { Contact }\end{array}$ & $\mathrm{ND}^{(\mathrm{b})}$ & ND & 3.0 & 5.2 & 8.2 \\
\hline
\end{tabular}

(a) TLD statistical variation on gamma readings are \pm 10 to $20 \%$, and on beta reading \pm 50 for the above data.

(b) $\mathrm{ND}=$ not determined.

TABLE 10. Site B Dose Rates from a $1.25 \%$-Enriched Fuel Element, $\mathrm{mrad} / \mathrm{h}^{(\mathrm{a})}$

\begin{tabular}{|c|c|c|c|c|c|}
\hline Instrument & $\begin{array}{c}\text { Open } \\
\text { Hindow }\end{array}$ & $\begin{array}{l}\text { Closed } \\
\text { Window }\end{array}$ & Gamma & Beta & Total \\
\hline $\begin{array}{l}\text { Ion Chamber "A" Contact } \\
15 \mathrm{~cm} \\
30 \mathrm{~cm}\end{array}$ & $\begin{array}{l}3.1 \\
0.5 \\
0.1\end{array}$ & $\begin{array}{l}1.85 \\
0.25 \\
0.0\end{array}$ & $\begin{array}{l}1.85 \\
0.25 \\
0.0\end{array}$ & $\begin{array}{l}6.6 \\
0.4 \\
0.1\end{array}$ & $\begin{array}{l}8.45 \\
0.65 \\
0.1\end{array}$ \\
\hline $\begin{array}{l}\mathrm{CP} " \mathrm{~B} "\left(208 \mathrm{~cm}^{3}\right) \text { Contact } \\
15 \mathrm{~cm} \\
30 \mathrm{~cm} \\
45 \mathrm{~cm}\end{array}$ & $\begin{array}{l}2.3 \\
0.75 \\
0.4 \\
0.2\end{array}$ & $\begin{array}{l}1.6 \\
0.5 \\
0.25 \\
0.15\end{array}$ & $\begin{array}{l}1.6 \\
0.5 \\
0.25 \\
0.15\end{array}$ & $\begin{array}{l}3.7 \\
0.4 \\
0.2 \\
0.1\end{array}$ & $\begin{array}{l}5.3 \\
0.9 \\
0.45 \\
0.25\end{array}$ \\
\hline $\begin{array}{l}\mathrm{CP} " \mathrm{Cl} "\left(463 \mathrm{~cm}^{3}\right) \text { Contact } \\
15 \mathrm{~cm} \\
30 \mathrm{~cm} \\
60 \mathrm{~cm}\end{array}$ & $\begin{array}{l}2.5 \\
0.8 \\
0.4 \\
0.25\end{array}$ & $\begin{array}{l}1.5 \\
0.5 \\
0.3 \\
0.1\end{array}$ & $\begin{array}{l}1.5 \\
0.5 \\
0.3 \\
0.1\end{array}$ & $\begin{array}{l}5.3 \\
0.4 \\
0.9 \\
0.2\end{array}$ & $\begin{array}{l}6.8 \\
0.9 \\
0.4 \\
0.3\end{array}$ \\
\hline \multicolumn{5}{|c|}{ Plastic Scintillator $\left(E_{\text {ave }}=400 \mathrm{keV}\right)$} & 5.8 \\
\hline $\begin{array}{l}\text { Multielement Dosimeter } \\
\text { Contact }\end{array}$ & $\mathrm{ND}^{(b)}$ & ND & 3.2 & 5.4 & 8.6 \\
\hline
\end{tabular}

(a) TLD statistical variation on gamma readings are \pm 10 to $20 \%$, and on beta reading \pm 50 a for the above data.

(b) $\mathrm{ND}=$ not determined. 
locations in the fuel fabrication building (Table 11). The maximum exposure for a person standing at location 1 (intermittent fuel storage area) for $8 \mathrm{~h} /$ day could not exceed $1600 \mathrm{mrad}$ for the year. If it were not for the zirconium cladding $(2 \mathrm{~mm})$ on the fuel elements, beta doses would be much higher.

TABLE 11. Dose Rate in Various Locations in the Uranium Fuel Fabrication Facility (Site B)

\begin{tabular}{|c|c|c|c|c|}
\hline \multirow[b]{2}{*}{ Location } & \multirow[b]{2}{*}{ Description } & \multicolumn{3}{|c|}{ Dose Rate, mrad/h } \\
\hline & & Beta & Gamma & Total \\
\hline 1 & Intermittent Fuel Storage Area & 0.19 & 0.61 & 0.80 \\
\hline 2 & Inspection Station & 0.17 & 0.21 & 0.38 \\
\hline 3 & Sandblast Cabinet & No $(a)$ & 0.02 & ND \\
\hline 4 & UItrasonic Testing & 0.10 & 0.13 & 0.23 \\
\hline 5 & Near Autoclaves & ND & 0.11 & ND \\
\hline 6 & Northwest Entrance & ND & 0.03 & ND \\
\hline
\end{tabular}

(a) ND = not determined.

\subsubsection{Site C: Separations Facility}

After the lid was removed from each waste tank sample at Site $C$, survey meter readings were taken with a $C P$ instrument. The beta dose rates were obtained by subtracting the closed window reading from the open window reading and multiplying by a factor of 2.5. This typical factor should be adequate, provided only beta particles from inside the sample bottle were detected. The measurement of contamination on the outside of the bottle would require a larger calibration factor due to the close proximity of the source to the detector. The survey meter dose rates are listed along with spectral dose rates, in Table 12. In three out of four liquid sample cases compared, the spectral dose rates were larger than the $C P$ dose rates. Also, a small portion of the spectrum near the origin was lost, due to the discriminator setting. Actual beta dose rates may be even larger than those listed based on a correction factor of 1.33 . 
TABLE 12. Site CDose Rates for Waste Tank Samples Measured with CP "C", $\mathrm{mrad} / \mathrm{h}$

\begin{tabular}{|c|c|c|c|c|c|}
\hline Sample & $\begin{array}{l}\text { Surv } \\
\text { Open Window } \\
\text { Reading, } \\
\mathrm{mrad} / \mathrm{h} \\
\end{array}$ & $\begin{array}{l}\text { Meter } \\
\text { Closed Window } \\
\text { Reading, } \\
\mathrm{mrad} / \mathrm{h} \\
\end{array}$ & $\begin{array}{c}\text { Beta }= \\
\text { Difference } \\
\times 2.5 \\
\end{array}$ & $\begin{array}{c}\text { Spectral } \\
\text { Beta Dose, } \\
\mathrm{mrad} / \mathrm{h} \\
\end{array}$ & $\begin{array}{l}\text { Spectra } 1 \\
\text { Average } \\
\text { Energy } \\
\end{array}$ \\
\hline $105 \mathrm{AW}$ & 30 & 10 & 50 & 130 & 980 \\
\hline $107 \mathrm{AN}$ & 700 & 90 & 1525 & 1140 & 1400 \\
\hline I05AN & 180 & 90 & 235 & 310 & 650 \\
\hline $102 \mathrm{AZ}$ & 200 & 80 & 300 & $N D^{(a)}$ & 1000 \\
\hline 104AN272 & 50 & 15 & 87 & 270 & 420 \\
\hline $102 \mathrm{AW}$ & 800 & 100 & 1750 & ND & 750 \\
\hline
\end{tabular}

(a) ND = not determined.

It is known from gamma analyses of the samples that the primary nuclide was ${ }^{137} \mathrm{Cs}$. The $32-\mathrm{keV} \times$ rays from the ${ }^{132} \mathrm{Cs}$ decay product $\left({ }^{137} \mathrm{Ba}\right)$ would be attenuated more by the $1000-\mathrm{mg} / \mathrm{cm}^{2}$ covering on the scintillation detector than the $400-\mathrm{mg} / \mathrm{cm}^{2}$ beta window of the survey meter. However, in this case it would change the reported beta doses by only a few percent, at the most. At Site $A$, where similar samples were measured with greater attenuation, the survey meter dose rates were larger than the spectral dose rates.

\subsubsection{Site D: Uranium Foundry}

At Site $D$, three of the site's routine survey meters were used for comparison with spectrometer results. These survey meters are typical of those used at other DOE facilities. Many of the survey meter and spectrometer dose rates (Table 13) exceeded $400 \mathrm{mrad} / \mathrm{h}$ with typical correction factors of 2.5 for survey meters and 1.33 for the spectrometer.

The published value for a uranium slab, with a $7-\mathrm{mg} / \mathrm{cm}^{2}$ cover, is about $230 \mathrm{mrad} / \mathrm{h}$ (Shleien and Terpilak 1984). This difference can be explained by the nonuniform deposition of uranium decay products. Apparently the short$l i$ ved progeny of ${ }^{238} U$ and ${ }^{235} U$ were depleted from the center of a molten mass of uranium and concentrated at the ends by chemical/physical processes. This resulted in a very high beta-to-gamma ratio and little attenuation for the 
TABLE 13. Site D Beta Dose Rates Measured with Spectrometers and Survey Meters

\begin{tabular}{|c|c|c|c|c|c|c|c|}
\hline \multirow[b]{2}{*}{$\begin{array}{l}\text { Radiation } \\
\text { Source }\end{array}$} & \multirow[b]{2}{*}{$\begin{array}{l}\text { Spectral } \\
\text { Analysis, } \\
\text { mrad/h }\end{array}$} & \multicolumn{3}{|c|}{ Survey Meters } & \multirow[b]{2}{*}{$\begin{array}{c}\text { PNL } \\
\text { Eight-El ement, } \\
\text { mrad/h } \\
\end{array}$} & \multicolumn{2}{|c|}{ Beta-to-Camma Ratios } \\
\hline & & $\begin{array}{r}\text { A, } \\
\mathrm{mrad} / \mathrm{h} \\
\end{array}$ & $\begin{array}{c}0, \\
\text { mrad/h }\end{array}$ & $\begin{array}{c}E, \\
\mathrm{mrad} / \mathrm{h} \\
\end{array}$ & & $\begin{array}{l}\text { Survey } \\
\text { Meter }\end{array}$ & $\begin{array}{l}\text { Eight- } \\
\text { Element } \\
\text { Dosimeter } \\
\end{array}$ \\
\hline $\begin{array}{l}\text { End Cut from } \\
\text { Uranium Billet }\end{array}$ & 390 & 400 & 560 & $\mathrm{ND}^{(a)}$ & 150 & $13: 1$ & $26: 1$ \\
\hline $\begin{array}{l}\text { Top of Uranium } \\
\text { Electrode Pour }\end{array}$ & 560 & 1200 & ND & ND & 790 & $10: 1$ & $84: 1$ \\
\hline $\begin{array}{l}\text { Uranium Elec- } \\
\text { trode Near } \\
\text { Midpoint }\end{array}$ & 90 & 280 & 200 & 130 & ND & $12: 1$ & ND \\
\hline $\begin{array}{l}18 \text { in. Above } \\
\text { Open Uranium } \\
\text { Crucible }\end{array}$ & 490 & ND & 530 & ND & No & $10: 1$ & ND \\
\hline
\end{tabular}

(a) NO = not determined.

surface material. However, the beta-to-gamma ratios show considerable variation both between the survey meter and the dosimeter and between the different locations. Much of this variation can be attributed to the position and size of the source relative to the measurement device.

The data in Table 13 result mostly from measurements taken at the surface of uranium metal. The uranium crucible is an exception. Also, the survey meters, dosimeters, and spectrometer were not placed at exactly the same position relative to the uranium metal. With these variables considered, the agreement among the results is reasonabiy good.

\subsubsection{Site E: Uranium Facility}

As at Site $D$, Site $E$ exposures were also due to uranium. However, measurements made during the first visit to Site $E$ (Table 14) revealed much lower dose rates than those recorded at Site $D$. This was partially due to a greater distance between the detectors and uranium surface (greater than $15 \mathrm{~cm}$ ) during the first measurements at Site $E$. In addition, the green salt at Site $E$ did not exhibit an increased concentration of uranium decay products at the surface. The residual uranium decay products on the inner surface of the crucible had apparently had time to decay. The measurement at $1.3 \mathrm{~cm}$ yielded about the same dose rate as the measurement at $15 \mathrm{~cm}$. 
TABLE 14. First Site E Beta Dose Rates Measured with Spectrometers and Survey Meters

\begin{tabular}{|c|c|c|c|c|c|c|}
\hline \multirow[b]{2}{*}{$\begin{array}{l}\text { Radiation } \\
\text { Source }\end{array}$} & \multirow[b]{2}{*}{$\begin{array}{l}\text { Spectra } 1 \\
\text { Analys is, } \\
\text { mrad } / \mathrm{h} \\
\end{array}$} & \multirow[b]{2}{*}{$\begin{array}{l}\frac{\text { Survey }}{D,} \\
\mathrm{mrad} / \mathrm{h}\end{array}$} & \multirow[b]{2}{*}{$\frac{\text { Meters }}{\mathrm{E},}$} & \multirow[b]{2}{*}{$\begin{array}{c}\text { PNL } \\
\text { Ejght-Element, } \\
\mathrm{mrad} / \mathrm{h} \\
\end{array}$} & \multicolumn{2}{|c|}{ Beta-to-Gamma Ratios } \\
\hline & & & & & $\begin{array}{l}\text { Survey } \\
\text { Meter }\end{array}$ & $\begin{array}{l}\text { Eight- } \\
\text { Element } \\
\text { Dosimeter }\end{array}$ \\
\hline $\begin{array}{l}15 \mathrm{~cm} \text { Above } \\
\text { Open Uranium } \\
\text { Crucible }\end{array}$ & 80 & 50 & 90 & 80 & $\mathrm{ND}^{(a)}$ & $160: 1$ \\
\hline Green Salt & 50 & 40 & 60 & 55 & ND & $70: 1$ \\
\hline Briquettes & 110 & 70 & 120 & 110 & $35: 1$ & $60: 1$ \\
\hline Hollow Fuel & 130 & 90 & 180 & 155 & $24: 1$ & $40: 1$ \\
\hline $\begin{array}{l}1.3 \mathrm{~cm} \text { Above } \\
\text { Inner Surface } \\
\text { of Crucible }\end{array}$ & 80 & 60 & 150 & ND & ND & ND \\
\hline
\end{tabular}

(a) ND = not determined.

The new thin scintillator prototype survey meter (survey meter $E$ ) used at Site $E$ seemed to be very consistent and accurate. It measured slightly higher dose rates than the other devices, as one would expect. Because the thin scintillator is only $5-\mathrm{mg} / \mathrm{cm}^{2}$ thick and is nearly tissue equivalent, it is a good approximation of the outer layer of human skin. Thus, measurements made with the thin scintillator can closely approximate skin doses.

The second set of measurements at Site $E$ produced much higher dose rates (Table 15). The measurements in this case were all taken at $0.6 \mathrm{~cm}$ from the surface of the uranium and/or decay products. The fuel element dose rate was close to that expected of a uranium slab; the briquette dose rate was similar to those seen at Site $D$; and the ingot wipe and inner glove surface dose rates were even higher. The crucible and outer glove surface dose rates approached those one would expect for an infinite plane source of ${ }^{234} \mathrm{Th}-{ }^{234 \mathrm{~m}} \mathrm{~Pa}$ (Cross et al. 1982). 
TABLE 15. Second Site E Beta Dose Rates Measured with Spectrometer and Survey Meter

\begin{tabular}{|c|c|c|c|c|}
\hline & $\begin{array}{c}\text { Spectral } \\
\text { Dose Rate, a }) \\
\mathrm{mrad} / \mathrm{h} \\
\end{array}$ & $\begin{array}{l}\text { Average } \\
\text { Energy, } \\
\text { keV } \\
\end{array}$ & $\begin{array}{c}\text { Survey } \\
\text { Instrument } \mathrm{C} \text {, } \\
\mathrm{mrad} / \mathrm{h} \\
\end{array}$ & $\begin{array}{c}\text { Beta-to-Gamma } \\
\text { Ratio } \\
\end{array}$ \\
\hline $\begin{array}{l}\text { Graphite Crucible } \\
\text { No } \mathrm{fiTtration} \\
20 \mathrm{mg} / \mathrm{cm}^{2}\end{array}$ & $\begin{array}{l}2320 \\
2070\end{array}$ & $\begin{array}{l}827 \\
776\end{array}$ & 2090 & $14: 1$ \\
\hline $\begin{array}{l}\text { Used Glove (outside surface) } \\
\text { No filtration } \\
20 \mathrm{mg} / \mathrm{cm}^{2}\end{array}$ & $\begin{array}{l}2448 \\
2110\end{array}$ & $\begin{array}{l}867 \\
833\end{array}$ & $N{ }^{(b)}$ & ND \\
\hline $\begin{array}{l}\text { Used Glove (inside surface) } \\
\text { No fi } 1 \text { tration } \\
20 \mathrm{mg} / \mathrm{cm}^{2}\end{array}$ & $\begin{array}{l}835 \\
620\end{array}$ & $\begin{array}{l}638 \\
623\end{array}$ & 680 & $18: 1$ \\
\hline $\begin{array}{l}\text { 8riquette } \\
\text { No filtration } \\
20 \mathrm{mg} / \mathrm{cm}^{2}\end{array}$ & $\begin{array}{l}402 \\
370\end{array}$ & $\begin{array}{l}770 \\
730\end{array}$ & 280 & $13: 1$ \\
\hline $\begin{array}{l}\text { Wipe from Ingot } \\
\text { No } \mathrm{fi} T \text { tration } \\
20 \mathrm{mg} / \mathrm{cm}^{2}\end{array}$ & $\begin{array}{l}876 \\
697\end{array}$ & $\begin{array}{l}642 \\
663\end{array}$ & 370 & $15: 1$ \\
\hline $\begin{array}{l}\text { Fuel Element } \\
\text { No filtration } \\
20 \mathrm{mg} / \mathrm{cm}^{2}\end{array}$ & $\begin{array}{l}200 \\
164\end{array}$ & $\begin{array}{l}580 \\
560\end{array}$ & 90 & $6: 1$ \\
\hline
\end{tabular}

(a) Dose rates calculated at $0.6 \mathrm{~cm}$ from surface of material based on beta radiation spectra for beta energies greater than $70 \mathrm{keV}$.

(b) ND $=$ not determined.

\subsubsection{Site F: Laboratory and Fuel Processing Facility}

Dose rate measurements at Site $F$ were taken in cooperation with a team of non-PNL. scientific investigators. Measurements were made in two different general locations using three commercial survey meters and two similar plastic scintillator spectrometers. The measurement results are shown in Table 16 . It is important to note that for these measurements, the center of the survey instrument (rather than the face) was used as the reference point. For the particular survey meters used, this allowed the beta dose to be read directly from the instruments rather than calculated with correction factors. With 
TABLE 16. Beta Measurements at Site F

\begin{tabular}{|c|c|c|c|c|c|c|c|c|}
\hline & \multirow{3}{*}{$\begin{array}{c}\text { Beta D } \\
\text { Scint. \#T, } \\
\text { mrad/h }\end{array}$} & \multirow{3}{*}{$\begin{array}{c}\text { Se Rate } \\
\text { Scint. } \# 2 \text {, } \\
\text { mrad/h }\end{array}$} & \multicolumn{6}{|c|}{ Survey Meters } \\
\hline & & & $A$ & & & & Th & \\
\hline & & & $\begin{array}{l}\text { Beta, } \\
\mathrm{mrad} / \mathrm{h}\end{array}$ & $\begin{array}{l}\text { Gamma, } \\
\mathrm{mrad} / \mathrm{h}\end{array}$ & $\begin{array}{l}\text { Beta, } \\
\mathrm{mrad} / \mathrm{h}\end{array}$ & $\begin{array}{l}\text { Gamma, } \\
\text { mrad/h }\end{array}$ & $\begin{array}{l}\text { Beta, } \\
\mathrm{mrad} / \mathrm{h}\end{array}$ & $\begin{array}{l}\text { Gama, } \\
\mathrm{mrad} / \mathrm{h}\end{array}$ \\
\hline $\begin{array}{l}\text { Soil in } \\
\text { HP } \\
\text { Laboratory }\end{array}$ & 69 & 67 & 58 & 7 & 68 & 0.5 & 64 & 0.7 \\
\hline $\begin{array}{l}60 \mathrm{~cm} \text { from } \\
\text { BI ister } \\
\text { Port, } \\
\text { Directly } \\
\text { in Front }\end{array}$ & $\$ 26$ & 190 & 150 & - & 160 & 6 & - & - \\
\hline
\end{tabular}

respect to the contaminated soil, the results show very good agreement for the various measurement devices and good accuracy if the extrapolation chamber result is taken as the true dose.

The results for the sampling port measurements (Table 16) are much more scattered. The position of the instruments relative to one another may have been an important factor here. Large changes in readings were noted with a vertical change of $5 \mathrm{~cm}$. Extrapolation chamber measurements at the sampling port are not available due to an equipment malfunction.

\subsubsection{Site G: Plutonium Production Reactor}

At Site $G$, only one survey instrument, "G", was used. With the center of the instrument at $11.4 \mathrm{~cm}$ above the array of fuel-tube caps, it read a beta dose rate of $390 \mathrm{mrad} / \mathrm{h}$ and a gamma dose rate of $32 \mathrm{mrad} / \mathrm{h}$. This compares to a beta dose rate of $230 \mathrm{mrad} / \mathrm{h}$ derived from the scintillation detector spectrum with the face of the detector at $8.3 \mathrm{~cm}$ above the array of fuel-tube caps. The average energy was $120 \mathrm{keV}$. Under these conditions, the scintillation detector received beta particles from four fuel-tube caps, while the survey instrument received additional beta particles from fuel-tube caps that were out to the side of the four directly below the instrument chamber. 


\subsection{SUMMARY OF MEASUREMENT RESULTS}

The following sections summarize the dosimeter and instrument measurements.

\subsubsection{Dosimeter Results}

Commercial and prototype dosimeters representative of those used at DOE facilities were placed at or near locations where radiation fields were measured with other devices. These dosimeter results along with those for the PNL eight-element dosimeters are listed in Table 16. The data in Table 16 result mostly from dosimeters placed at various distances from some form of uranium. The exceptions occurred at Sites $A$ and $F$; these are discussed last.

At sites where doses were from uranium, the eight-element dosimeters generally recorded higher dose rates than the other dosimeters. A notable departure from this trend occurred from a measurement of the end cut from a uranium billet at Site $D$. Although there was a variation in dose rate at different points on the billet end cut, the variation was not as high as indicated by the dosimeter results. In addition, a survey meter reading taken where the eight-element dosimeter was placed indicated that the location had a higher dose rate than other points on the surface. Thus, the result for the eight-element dosimeter must be accepted as anomalous in this case. At Site $D$, the most accurate dosimeter results (compared to the eight-element results) were provided by a PNL two-element dosimeter containing either $17-\mathrm{mg} / \mathrm{cm}^{2}$ or $235-\mathrm{mg} / \mathrm{cm}^{2}$ TLDs. A commercial four-element dosimeter with a modification of the thinnest filter and a revised algorithm was the most accurate at Site $\mathrm{E}$, followed by the two-element PNL dosimeter with $235-\mathrm{mg} / \mathrm{cm}^{2}$ TLDs. At Sites $D$ and $E$, the two-element PNL dosimeter with $100-\mathrm{mg} / \mathrm{cm}^{2}$ TLDs responded similarly to the same dosimeter with $235-\mathrm{mg} / \mathrm{cm}^{2} \mathrm{TLDs}$, but the thinner TLD results were more erratic. The second commercial four-element dosimeter and the commercial two-element dosimeters tended to have low responses (approximately one-half) relative to the eight-element results. At Site $F$, only the two-element dosimeters with $100-\mathrm{mg} / \mathrm{cm}^{2}$ and $235-\mathrm{mg} / \mathrm{cm}^{2}$ TLDs were exposed at the same point as the eight-element dosimeter; they had the low response just discussed. At site $A$, the $235-\mathrm{mg} / \mathrm{cm}^{2}$ TLD response was 


\section{TABLE 17. Response of Dosimeters to Beta Radiation at DOE Facilities}

\begin{tabular}{|c|c|c|c|c|c|c|c|c|}
\hline Site & Location & $\begin{array}{l}\text { PNL. Eight- } \\
\text { Element, } \\
\text { mrad/h } \\
\end{array}$ & $\begin{array}{l}\text { Two-El ement } \\
\begin{array}{l}17 \mathrm{mg} / \mathrm{cm}^{2} \\
\mathrm{mrad} / \mathrm{h}\end{array}\end{array}$ & $\begin{array}{l}\text { Two-El ement } \\
100 \mathrm{mg} / \mathrm{cm}^{2}, \\
\mathrm{mrad} / \mathrm{h}\end{array}$ & $\begin{array}{l}\text { Two-Element } \\
235 \mathrm{mg} / \mathrm{cm}^{2}, \\
\mathrm{mrad} / \mathrm{h} \\
\end{array}$ & $\begin{array}{l}\text { Four-El ement } \\
\text { Commercial, } \\
\mathrm{mrad} / \mathrm{h}(\mathrm{a}) \\
\end{array}$ & $\begin{array}{c}\text { Four-Element } \\
\text { Commercial, } \\
\mathrm{mrad} / \mathrm{h} \\
\end{array}$ & $\begin{array}{c}\text { Two-Element } \\
\text { Commercial, } \\
\text { mrad/h } \\
\end{array}$ \\
\hline A & Process Sampie & 580.0 & 430.0 & 380.0 & 920.0 & No ${ }^{(a)}$ & 50.0 & 230.0 \\
\hline D & $\begin{array}{l}\text { End Cut from } \\
\text { Uranium Billet }\end{array}$ & 150.0 & 390.0 & 480.0 & 510.0 & ND & 200.0 & 280.0 \\
\hline & $\begin{array}{l}\text { Top of Uranium } \\
\text { Electrode Pour }\end{array}$ & 790.0 & 270.0 & 160.0 & 740.0 & ND & ND & 340.0 \\
\hline & $\begin{array}{l}\text { Charge Makeup at } \\
1 \text { Meter }\end{array}$ & 1.1 & 0.9 & 0.7 & 0.7 & ND & 0.5 & 0.4 \\
\hline & General Area $\# 1$ & 0.5 & 0.4 & 0.4 & 0.4 & ND & 0.2 & 0.2 \\
\hline & Ceneral Area $\# 2$ & 4.8 & 2.4 & 2.3 & 2.5 & ND & 2.5 & 1.6 \\
\hline & Ceneral Area \#3 & 2.9 & 1.4 & 1.4 & 1.0 & ND & 1.0 & 0.6 \\
\hline & Ceneral Area \#4 & 0.6 & 0.6 & 0.5 & 1.0 & ND & 0.1 & 0.3 \\
\hline & General Area \#5 & 5.9 & 1.0 & 1.6 & 3.4 & ND & 0.8 & 0.5 \\
\hline & General Area \#6 & 1.0 & 1.2 & 0.9 & 0.9 & ND & 0.6 & 0.6 \\
\hline $\mathrm{E}$ & $\begin{array}{l}15 \mathrm{~cm} \text { Above Open } \\
\text { Uranium Crucible }\end{array}$ & 80.0 & ND & 80.0 & 65.0 & 65.0 & 11.0 & 31.0 \\
\hline & Green Salt & 55.0 & ND & 45.0 & 45.0 & 50.0 & 28.0 & 27.0 \\
\hline & Briquettes & 110.0 & ND & ND & NO & 85.0 & 50.0 & 62.0 \\
\hline & Hollow Fuel Rods & 155.0 & 165.0 & 220.0 & 160.0 & 120.0 & 65.0 & 66.0 \\
\hline $\mathrm{F}$ & Contaminated Soil & 92.0 & ND & ND & 38.0 & ND & 43.0 & ND \\
\hline
\end{tabular}

(a) ND $=$ not determined. 
abnormally high, the four-element commercial dosimeter response was very low, and the other dosimeters followed the trend described for Sites $D$ and $E$.

\subsubsection{Instrument Results}

In addition to measurements made with the silicon diode and scintillation spectrometer, commercial and prototype instruments were compared with spectral measurements when available. Selected measurements are summarized in Table 18 and discussed in more detail in the sections on the specific site measurements. Table 18 also shows the results for the eight-element dosimeter when measurements were made in the same location.

As one can see from the table, the measurements made with survey meters tend to be higher than dose rates determined by analysis of the spectral data. Ion chamber instruments ( $A, B$, and $C$ ) show reasonable agreement with spectral data, particularly in the high-energy beta exposure conditions (Sites $D, E$, and F). The developmental thin scintillator (Johnson et al. 1983) showed good agreement with the spectral analysis results in the limited testing performed. 
TABLE 18. Response of Instruments to Beta Radiation at Department of Energy Facility

\begin{tabular}{|c|c|c|c|c|c|c|c|c|}
\hline Site & Location & $\begin{array}{l}\text { Spectral } \\
\text { Analys is, } \\
\mathrm{mrad} / \mathrm{h} \\
\end{array}$ & $A^{(a)}$ & $\frac{B^{(a)}}{{ }^{(a)}}$ & $\frac{\text { er Read }}{c^{(a)}}$ & $\frac{\mathrm{gs}, \operatorname{mra}}{\mathrm{D}^{(b)}}$ & $E^{(c)}$ & $\begin{array}{l}\text { Eight- } \\
\text { Element } \\
\text { Dosimeter, } \\
\mathrm{mrad} / \mathrm{h} \\
\end{array}$ \\
\hline $\begin{array}{l}A \\
A\end{array}$ & $\begin{array}{l}\text { Process Sample } \\
\text { Waste Sample }\end{array}$ & $\begin{array}{l}610 \\
270\end{array}$ & $\begin{array}{l}840 \\
360\end{array}$ & $\mathrm{ND}^{(\mathrm{d})}$ & ND & ND & ND & $\begin{array}{l}730 \\
110\end{array}$ \\
\hline $\begin{array}{l}B \\
B\end{array}$ & $\begin{array}{l}\text { Fuel Element (contact) } \\
\text { Fuel Element }(\text { contact) }\end{array}$ & $\begin{array}{l}3.6 \\
5.8\end{array}$ & $\begin{array}{l}5.1 \\
8.5\end{array}$ & $\begin{array}{l}4.2 \\
5.3\end{array}$ & $\begin{array}{l}7.2 \\
6.8\end{array}$ & $\begin{array}{l}\text { ND } \\
\text { ND }\end{array}$ & $\begin{array}{l}\text { ND } \\
\text { ND }\end{array}$ & $\begin{array}{l}8.2 \\
8.6\end{array}$ \\
\hline $\begin{array}{l}\mathrm{C} \\
\mathrm{C}\end{array}$ & $\begin{array}{l}\text { Waste Sample } \\
\text { Waste Sample }\end{array}$ & $\begin{array}{l}130 \\
270\end{array}$ & $\begin{array}{l}\text { ND } \\
\text { ND }\end{array}$ & $\begin{array}{l}\text { NO } \\
\text { ND }\end{array}$ & $\begin{array}{l}50 \\
87\end{array}$ & $\begin{array}{l}\text { ND } \\
\text { ND }\end{array}$ & $\begin{array}{l}\text { ND } \\
\text { ND }\end{array}$ & $\begin{array}{l}\text { ND } \\
\text { ND }\end{array}$ \\
\hline $\begin{array}{l}\mathrm{D} \\
\mathrm{D}\end{array}$ & $\begin{array}{l}\text { Uranium Billet } \\
\text { Uranium Electrode }\end{array}$ & $\begin{array}{r}390 \\
90\end{array}$ & $\begin{array}{l}400 \\
280\end{array}$ & $\begin{array}{l}\text { ND } \\
\text { ND }\end{array}$ & $\begin{array}{l}\text { ND } \\
\text { ND }\end{array}$ & $\begin{array}{l}560 \\
200\end{array}$ & $\begin{array}{l}\text { ND } \\
130\end{array}$ & $\begin{array}{r}150 \\
\text { ND }\end{array}$ \\
\hline $\begin{array}{l}E \\
E\end{array}$ & $\begin{array}{l}\text { Uranium Crucible } \\
\text { Hollow Fuel Element }\end{array}$ & $\begin{array}{r}80 \\
130\end{array}$ & $\begin{array}{l}\text { ND } \\
\text { ND }\end{array}$ & $\begin{array}{l}\text { ND } \\
\text { ND }\end{array}$ & $\begin{array}{l}\text { ND } \\
\text { ND }\end{array}$ & $\begin{array}{l}50 \\
90\end{array}$ & $\begin{array}{r}90 \\
180\end{array}$ & $\begin{array}{r}80 \\
155\end{array}$ \\
\hline $\begin{array}{l}F \\
F\end{array}$ & $\begin{array}{l}\text { Contaminated Soil } \\
\text { Blister Port }\end{array}$ & $\begin{array}{r}69 \\
126\end{array}$ & $\begin{array}{r}58 \\
150\end{array}$ & $\begin{array}{r}68 \\
160\end{array}$ & $\begin{array}{l}\text { ND } \\
\text { ND }\end{array}$ & $\begin{array}{l}\text { ND } \\
\text { ND }\end{array}$ & $\begin{array}{l}64 \\
\text { ND }\end{array}$ & $\begin{array}{l}\text { ND } \\
\text { ND }\end{array}$ \\
\hline $\begin{array}{l}\text { (a) } \\
\text { (b) } \\
\text { (c) } \\
\text { (d) } \\
\text { (e) }\end{array}$ & $\begin{array}{l}\text { chamber instruments. } \\
\text { iger-Mueller detector and } \\
\text { in scintillation detector } \\
=\text { not determined. } \\
\text { dings are total dose at co }\end{array}$ & $\begin{array}{l}\text { unt rate me } \\
\text { rvey meter. } \\
\text { tact. }\end{array}$ & er. & & & & & \\
\hline
\end{tabular}




\subsection{CONCLUSIONS AND RECOMMENDATIONS}

\subsection{BETA EXPOSURES}

Seven different DOE facilities were visited during the course of the field measurement described in this report. This represents one-fourth of the DOE facilities that have beta measurement programs (Mulvehill et al. 1987). Five of these facilities were selected based on the probability that beta radiation dose rates exceeded photon dose rates. Thus, the results reported may be biased towards higher beta dose rates than typically experienced at DOE facilities.

In laboratories or field conditions where large quantities of unshielded material were present, high beta-to-ganma ratios were observed. The beta dose rates under these conditions were of ten hundreds of mrad per hour, and thus, beta spectra were easy to observe and analyze. Where fission products were found, or where uranium was shielded in the actual work locations, the resulting low beta-to-gamma ratios made interpretation of beta spectra difficult. Low-energy (less than $200 \mathrm{keV}$ ) beta fields caused additional difficulties due to the nonlinear energy response of beta spectrometers.

Analyses of beta and gamma spectra showed that ${ }^{234} \mathrm{Th}-{ }^{234 \mathrm{~m}} \mathrm{~Pa},{ }^{231} \mathrm{Th}$, ${ }^{137} \mathrm{Cs}$, and ${ }^{90} \mathrm{Sr} /{ }^{90} Y$ were the major nuclides contributing to beta doses. In addition to ${ }^{137} \mathrm{Cs}$ and ${ }^{90} \mathrm{Sr} /{ }^{9 \mathrm{D}} \mathrm{Y}$, other fission products and ${ }^{60} \mathrm{Co}$ were present in smaller quantities.

At facilities where mixed fission products were present, handling and control procedures developed to control internal exposures and exposure to penetrating radiations were also effective in controlling beta dose rates to workers. At facilities where large amounts of uranium were handled $\left({ }^{234} \mathrm{Th}\right.$ ${ }^{234} \mathrm{~m} \mathrm{~Pa}$ and ${ }^{231} \mathrm{Th}$ ) in the metal form the beta dose rates were higher. Even though the contact dose rates from fission product samples often exceeded the contact dose rates from uranium decay products, the opportunity for routine contact with the uranium decay products appeared to be much greater.

Workers exposed to mixed fission product fields typically wore at least two pairs of gloves taped to full-length outer protective clothing. Eye protection was usually available and small samples were handled in fume hoods 
or glove boxes. In larger enclosures where fission products existed, workers wore full-face masks. The use of long-handled tongs and lead containers also reduced exposures to fission products. Existing equipment and procedures for personnel contamination monitoring at facilities where fission products were present minimized the opportunity for undetected skin contamination.

At facilities where short-lived uranium decay products were the major source of beta exposure, workers typically wore heavy leather work gloves but no inner gloves or tape. These workers often stood close to large pieces of cast uranium metal, furnaces, and graphite crucibles. The surfaces of the uranium and the surfaces of associated processing and handiing equipment were typically covered with a black film containing carbon from the crucibles and uranium highly enriched in ${ }^{234} \mathrm{Th}-{ }^{234 \mathrm{~m}_{\mathrm{Pa}}}$ and ${ }^{231} \mathrm{Th}$. When uranium is melted, the thorium that has grown in from ${ }^{238_{U}}$ and ${ }^{235} U$ apparently moves preferentially to the outside of the molten solution and remains there while the metal resolidifies. This results in a thin film of much higher beta activity than the typical uranium slab, in which the uranium decay products are homogeneously mixed with the uranium. Because ${ }^{231}$ Th has a half-life of approximately one day, it will virtually decay away after one week. However, ${ }^{234}$ Th (halflife 24 days) will continue to provide significant beta emissions for up to six months. Protactinium- $234 \mathrm{~m}$ is always in equilibrium with ${ }^{234} \mathrm{Th}$. Protactinium-234m has a $2.3-\mathrm{MeV}$ beta particle (maximum energy) that can penetrate several meters of air.

The other beta emitters associated with the immediate decay products of uranium are important only for skin contact doses and internal doses. Rapid accumulation of black, uranium decay product dust on the outside of workers' gloves (worn for physical protection) and the opportunity for the interior of the gloves to become contaminated made dose rates to the hands potentially large. Dose rates of greater than $800 \mathrm{mrad} / \mathrm{h}$ were measured on the inside of one glove (see Table 14). 


\subsection{SURVEY METERS}

Beta dose rates measured by five different commercial models of survey meters were typically higher than the accepted values when the face of the instrument was taken as the reference point and a carefully considered correction factor was applied. For a hardened beta spectrum $\left({ }^{90} Y\right)$ a correction factor near unity was adequate. However, typical correction factors of 2.5 were often not large enough for $\mathrm{CP}$-type instruments used to measure lightly filtered beta fields.

The best survey meter results for the commercial instruments were obtained when the center of the instrument was taken as the reference point. Because of the availability of spectral information and the opportunity for careful analyses, the correction factors used in this report were probably more accurate than a single correction factor that might be applied at a typical DOE facility.

The prototype beta-plus-gamma dose rate meter developed at INEL was used briefly at Site E. Based on data from this limited application, the prototype survey instrument appeared to produce very good results.

\subsection{DOSIMETERS}

Typical dosimeters usually had a lower response to beta radiation than the PNL eight-element dosimeter. Two commercial dosimeters (two-element and four-element) responded approximately $50 \%$ less than the PNL eight-element dosimeter. However, a second four-element commercial dosimeter and PNLprototype two-element dosimeters containing three different thicknesses of TLO typically responded within 70 to $80 \%$ of the eight-element dosimeter. A thinner filter on the "beta" (PNL prototype) dosimeter and, in the case of the four-element dosimeter, an improved algorithm appeared to cause the better response. The dosimeter containing the $\mathrm{KSU}$ thin $\left(17-\mathrm{mg} / \mathrm{cm}^{2}\right)$ TLO responded equally to the same type of dosimeter containing $235-\mathrm{mg} / \mathrm{cm}^{2} \mathrm{TLDs}$. This indicates that most beta fields the thin TLDs were exposed to consisted of higher energy beta particles. 
In some cases, the results from the PNL eight-element dosimeter appeared to be erratic. The influence of low-energy photons may haved casued these erratic results. Because the eight-element dosimeter was used to compare other dosimeter results, any deviation in the eight-element dosimeters results affected the evaluation of the other dosimeters.

\subsection{RECOMMENDATIONS}

Based on the measurements made at the DOE facilities and observations during the measurements, several recommendations can be made. These recommendations are listed below.

- Further studies of detector response at energies below $200 \mathrm{keV}$ should be undertaken to determine the degree of detector nonlinearity and its influence on dose calculations.

- Studies are needed on the influence of backscatter from detectors and detector windows on beta spectra and beta dose calculations.

- Further studies should be performed on the eight-element dosimeters to determine their response in mixed fields dominated by low-energy photons.

- A dosimeter similar to the eight-element unit, but using stacked elements should be developed. This would eliminate the concern about the spatial response of the present multielement dosimeter and permit the study of spatial variations in radiation fields.

- Dosimeters used in beta fields at DOE facilities should have a thin window (less than $20 \mathrm{mg} / \mathrm{cm}^{2}$ ) over the beta element.

- Conventional $235 \mathrm{mg} / \mathrm{cm}^{2}$ TLDs should be replaced by thin TLDs $\left(17 \mathrm{mg} / \mathrm{cm}^{2}\right.$ ) in dosimeters used to monitor beta exposures.

- Dosimeters should be calibrated to beta energies similar to those encountered in the work areas. Yttrium-90 calibrations provide too energetic a beta spectrum for many applications. 
- The influence of source geometry and source-detector distance on measurements should be known for each instrument used in a facility. Whenever possible, measurements should be made to determine the correction factors.

- Personnel should be trained to use correction factors for source energy, source geometry, and source-to-detector distance on dose rate measurements.

- The variation in response of instruments with beta energy and angle of incidence should be documented.

- A modified ionization chamber instrument with a large-area, shallow chamber should be available for beta-dose-rate measurements.

- The thin scintillator should be further developed for field measurements.

- Workers who handle uranium metal products and associated processing materials should be made aware of the potentially high contact beta dose rates.

- Radiation protection procedures should be improved for workers in facilities where uranium decay products present beta dose probiems. Contamination control, protective clothing, and dosimeter placement should be addressed. 


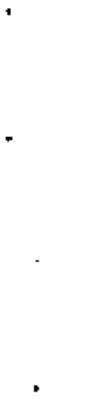

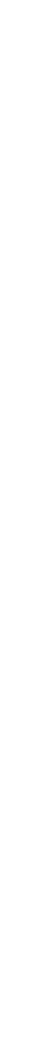




\section{REFERENCES}

Attix, F. H., and W. C. Roesch, eds. 1968. Vol. 1 of Radiation Dosimetry. 2nd ed. Academic Press, New York.

Birks, J. B. 1964. The Theory and Practice of Scintillation Counting, pp. 185-189. Pergamon Press Limi ted, Oxford, England.

Cross, W. G., H. Ing, N. O. Freedman, and J. Mainville. 1982. Tables of Beta-Ray Dose Distributions in Water, Air and Other Media. AECL-7617, Atomic Energy of Canada Limited, Ontario, Canada.

Cross, W. G., H. Ing, N. O. Freedman, and J. Mainville. 19B4. "Beta Spectra and Tables of Beta Ray Dose 0istributions." In Proceedings of the International Beta Dosimetry Symposium. NUREG/CP-005D, U.S. Department of Energy/ U.S. Nuclear Regulatory Commission/Heal th Physics Society, Washington, D.C.

Fox, R. J., and C. J. Borkowski. 1962. "Silicon Surface Barrier Detectors with High Reverse Breakdown Voltages." IRE Trans. Nucl. Sci. NS-9(3):213.

International Commission on Radiological Protection (ICRP). 1977. Recommendations of the International Commission on Radiation Protection. ICRP Publication 26, Pergamon Press, oxford.

International Organization of Standardization. 1981. Reference Beta Radiations for Calibrating Dosemeters and Dose Ratemeters and for Determining Their Response as a Function of Beta Radiation Energy. ISO/DP 6980, International Organization of Standardization, Geneva, Switzerland.

Johnson, L. 0., J. L. Alvarez, V. P. Gupta, and B. L. Rich. 1983. "Pulse Shape Discrimination in a Portable Beta-Gamma Dose Rate Meter." IEEE Trans. Nuc. Sci. NS-30:543.

Jones, A. R. 1984. "A Review of Techniques and Detectors Used in Instruments for Field Measurement of Beta Doses and Dose Rates." In Proceedings of the International Beta Dosimetry Symposium. NUREG/CP-0050, U.S. Department of Energy/U.S. Nuclear Regulatory Commission/Heal th Physics Society, Washington, D.C.

Mulvehill, J. M., L. W. Brackenbush, K. L. Swinth, and E. J. Vallario. 1987. Characteristics of Beta Detection and Dose Measurements at Department of Energy Facilities. PNL-5960, Pacific Northwest Laboratory, Richland, Washington.

Murphy, R. 0., J. W. Poston, and K. R. Baker. 1984. "A Dosimetry Technique for Beta Radiation Fields in the Nuclear Power Industry: A Progress Report." In Proceedings of the International Beta Dosimetry Symposium. NUREG/CP-0050, U.S. Department of Energy/U.S. Nuclear Regulatory Commission/ Health Physics Society, Washington, D.C. 
Murphy, R. 0., and J.W. Poston. 1984. "A Dosimetry Technique for Beta Radiation Fields in the Nuclear Power Industry." Proceedings of the International Beta Dosimetry Symposium, NUREG/CP-0050, U.S. Department of Energy/J.S. Nuclear Regulatory Commission/Health Physics Society, Washington, D.C.

Rathbun, L. A., G. W. R. Endres, R. A. Fox, P. L. Roberson, and R. I. Scherpelz. 1984. Beta Particle Measurement and Dosimetry Requirements at NRC-Licensed Facilities. NUREG/CR-3544, U.S. Nuclear Regulatory Commission, Washington, D.C.

Roesch, W. R., and E. E. Donaldson. 1956. "Portable Instruments for Beta-Ray Dosimetry." In Proceedings of the International Conference on the Peacesfu? Uses of Atomic Energy, Vol. 14, General Aspects of the Use of Radioactive Isotopes: Dosimetry. United Nations, New York.

Roesch, W. C. 1984. "Field Practices and Techniques: Introduction." In Proceedings of the International Beta Dosimetry Symposium. NUREG/CP-0050, U.S. Department of Energy/U.S. Nuclear Regulatory Commission/Heal th Physics Society, Washington, D.C.

ScherpeIz, R. I., G. W. R. Endres, and L. A. Rathbun, 1984. The Use of MuTti-Element Beta Dosimeters for Measuring Dose Rates in the TMI-2 Containment Building. PIL-4714, Pacific Northwest Laboratory, Richiand, Washington.

Scherpelz, R. I., G. W. R. Endres, and P. L. Roberson. 1984. "The Application of a Multi-Element Beta Dosimeter." In Proceedings of the Internationa] Beta Dosimetry Symposium. NUREG/CP-D050, U.S. Department of Energy/U.S. Nuclear Regulatory Commission/Health Physics Society, Washington, D.C.

Selby, J. M., K. L. Swinth, C. D. Hooker, and J. L. Kenoyer. 1984. "Field Measurement and Interpretation of Beta Doses and Dose Rates." In Proceedings of the International Beta Dosimetry Symposium. NUREG/CP-0050, U.S. Department of Energy/U.S. Nuclear Regulatory Commission/Health Physics Society, Washington, D.C.

Shleien, B., and M. S. Terpilak. 1984. The Health Physics and Radiological Heal th Handbook. Nucleon Lectern Associates, OTney, Maryland.

Simons, G. G., T. M. DeBey, R. B. Stuewe, and K. D. Stansbury. 1982. Beta Dosimetry and Spectroscopy. Annual Report prepared by Kansas State $\sqrt{n i v e r s-}$ ity, Department of Nuclear Engineering, Manhattan, Kansas for Pacific Northwest Laboratory under Subcontract No. B-B4345-A-X.

Wohn, F. K., J. R. Clifford, G. H. Carison, and W. L. Talbert, Jr. 1972. "A Plastic Scintillation Detector for Beta-Ray Spectrum Measurements." Nuc. Instru. Meth. 101:343. 


\section{DISTRIBUTION}

No. of

Copies

OFFSITE

30 Technical Information Center

DOE Headquarters

R. W. Barber, Director Office of Nuclear Safety

U.S. Department of Energy

Washington, DC 20545

R. P. Berube, Director Assistant Secretary for Environment, Safety, and Health Washington, DC 20545

D. F. Bunch, Acting Deputy Assistant Secretary for Safety, Health, and Quality Assurance

U.S. Department of Energy

Washington, DC 20545

N. Goldenberg, Acting Director

Quality Assurance

U.S. Department of Energy

Washington, DC 20545

Bette L. Murphy

Office of Nuclear Safety

U.S. Department of Energy

Washington, DC 20545

25 E. J. Vallario, Acting Director Division of Radiological Controls U.S. Department of Energy Washington, DC 20545

M. Walker

Assistant Secretary for

Environment, Safety, and Health

U.S. Department of Energy

Washington, DC 20545
No. of

Copies

DOE Albuquerque Operations Office

R. E. Alexander, Safety Director Pantex Plant

Mason \& Hanger--Silas Mason Co., Inc.

P.0. Box 3D020

Amarillo, TX 79177

W. D. Burnett, Manager

DOE Sandia National Laboratories

Mail Code 3312, B1dg. 8619

P.0. Box 2800

A]buquerque, NM 87115

G. W. Campbe11

Rockwell International Corp.

Rocky Flats Plant

P.0. Box 464

Golden, C0 80401

D. Krenz

U.S. Department of Energy

A)buquerque Operations 0ffice

P. 0. Box 5400

Albuouerque, NM 87115

H. E. Meyer, Manager

Mound Laboratory

Monsanto Research Corporation

Miamisburg, OH 45342

P. M. Ramey

U.S. Department of Energy

ATbuquerque Operations Office

P.0. Box 5400

A1buquerque, NM 87115

R. G. Stafford

Los Alamos National Laboratory

P.0. Box 1663

Los Alamos, NM 87545 
No. of

Copies

J. G. Themelis

U.S. Department of Energy

Albuquerque Operations Office

P.0. Box 5400

Alburquerque, NM 87115

A. M. Valentine

Los Alamos National Laboratory

P.0. Box 1663

Los Alamos, NM 87545

DOE Chicago Operations office

D. L. Bray

U.S. Department of Energy

9800 S. Cass Ave.

Argonne, IL 60439

L. V. Coutson

Fermi National Accelerator Laboratory

P.0. Box 500

Batavia, IL 60510

E. H. Dolecek

Argonne National Laboratory

9800 5. Cass Ave., Bldg. 201

Argonne, IL 60439

C. B. Meinhold

Brookhaven National Laboratory

Associated Universities, Inc.

Upton, NY 11973

R. Moser

U.S. Oepartment of Energy

Chicago Operations Office

9800 South Cass Avenue

Argonne, IL 60439

D. P. O'Neil

Argonne National Laboratory

9800 S. Cass Avenue

Argonne, IL 60439
No. of

Copies

DOE Idaho Operations Office

J. H. Barry

U.S. Department of Energy

Idaho Operations office

785 D0E Place

Idaho Falls, ID 83402

T. F. Gesel1

U.S. Department of Energy

Idaho Operations Office

550 2nd Street

Idaho Falis, ID 83401

B. L. Rich

EG\&G Idaho

P.0. Box 1625

Idaho Falls, ID 83401

A. N. Tschaeche

WINCO

$M / S$ CPP -630

P.0. Box 4000

Idaho Falls, ID 83403

DOE Naval Reactors Office

T. L. Coltins

U.S. Department of Energy

Knolls Atomic Power Laboratory

P.0. Box 1072

Schenectady, NY 12301

A. C. Davis

Westinghouse Electric Corporation

Bettis Atomic Power Lab. (DOE)

P.0. Box 79

West Mifflin, PA 15122

C. K. Gaddis

Pittsburgh Naval Reactors Office

P.0. Box 109

W. MiffTin, PA 15122 
DOE Nevada Operations Office

A. E. Bicker

Reynolds Electrical \& Engineering Co., Inc.

P.0. Box 14400

Las Vegas, NV 89114

B. W. Church

U.S. Department of Energy

Nevada Operations Office

P.0. Box 14100

Las Vegas, NV 89114

S. R. Elliot

U.S. Department of Energy

Nevada Operations Office

P.0. Box 14100

Las Vegas, NV 89114

DOE Oak Ridge Operations Office

W. F. Furth

Martin Marietta Energy Systems

P.0. Box $X$

Oak Ridge, TN 37831

R. E. Halliburton

Oak Ridge National Laboratory

P.0. Box $X$

Oak Ridge, TN 38730

S. L. Hinnefeld

Westinghouse Materials Co. of Ohio

P.0. Box 39B704

Cincinnati, $\mathrm{OH} 45239$

D. B. Howard

U.S. Department of Energy

0ak Ridge Operations Office

P.O. Box E

Oak Ridge, TN 37831
T. M. Jelinek

U.S. Department of Energy

Oak Ridge Operations Office

P.0. Box E

Oak Ridge, TN 37831

W. T. Mee

$\mathrm{Y}-12$

P.0. Box $Y$

Oak Ridge, TN 37830

D. C. Parzyck

Oak Ridge National Laboratory

P.0. Box X

Oak Ridge, TN 37830

B. G. Roach

Oak Ridge Associated Universities

P.0. Box 117

Oak Ridge, TN 37831

S. F. Seltzer

Paducah Gaseous Diffusion Plant

P.0. Box 1410

Paducah, KY 42001

J. Shoemaker

Oak Ridge Gaseous Diffusion Plant

P.0. Box P

Oak Ridge, TN 37831

F. G. VanLoocke

RMI Company

P.0. Box 579

AshtabuTa, OH 44004

E. R. Wagner

Portsmouth Gaseous Diffusion Plant

Martin Marietta Energy Systems

P.0. Box 628

Piketone, $\mathrm{OH} 45661$ 
No. of

Copies

DOE San Francisco Operations

Office

T. R. Crites

Lawrence Livermore National

Laboratory

P.0. Box 5505

Livermore, CA 94550

J. T. Davis

U.S. Department of Energy

San Francisco Operations Office

1333 Broadway

Oakland, CA 94612

R. V. Griffith

Lawrence Livermore Nationa T

Laboratory

P.0. Box 5505

Livermore, CA 94550

W. E. Keheley

U.S. Department of Energy

San Francisco Operations

Office

1333 Broadway

Oakland, CA 94612

R. C. McCalt

Stanford Linear Accelerator

P.0. Box 4349

Stanford, CA 94305

P. L. Phelps

Lawrence Livermore Nationa 1

Laboratory

P.0. Box 5505

Livermore, 'CA 94550

R. H. Thomas

DOE Lawrence Berkeley National Laboratory

University of California

Berkeley, CA 94720
No. of

Copies

A. J. Toy

Lawrence Livermore Nationa?

Laboratory

P.0. Box 808

Livermore, CA 94550

DOE Savannah River Operations

Office

D. N. Bridges

U.S. Department of Energy

Savannah River Operations Office

P.0. Box A

Aiken, SC 29801

R. M. Hall

E.I. duPont de Nemours \& Co.

Savannah River Plant

Aiken, SC 29809

W. A. Reese

U.S. Department of Energy

Savannah River Operations Office P.0. Box A

Aiken, SC 29801

W. C. Reinig

E.I. duPont De Nemours \& Co.

Savannah River Plant

Aiken, SC 29809

EPA Office of Radiation Programs

A. Richardson

401 M Street, SW

Washington, DC 20460

National Center for Devices and Radiological Heaith

J. C. Villforth

FDA Bureau of Radiological Health

Rockville, MD 20852 
No. of

Copies

National Bureau of Standards

Ronald Colle'

National Bureau of Standards

Gaithersburg, MD 20899

E. H. Eisenhower

National Bureau of Standards

Gaithersburg, MD 20899

Robert Loevinger

National Bureau of Standards

Gaithersburg, MD 20899

Robert B. Schwartz

National Bureau of Standards

Gaithersburg, MD 20899

Nuclear Regulatory Commission

R. E. Alexander

U.S. Nuclear Regulatory Commission Washington, DC 20555

L. K. Cohen

U.S. Nuclear Regulatory Commission Washington, DC 20555

l. J. Cunningham

U.S. Nuclear Regulatory Commission Washington, DC 20555

other

I. Fisenne

U.S. Department of Energy

Environmental Measurement Laboratory

376 Hudson St.

New York, NY 10014
No. of

Copies

ONSITE

4 DOE Richland Operations Office

R. E. Gerton

D. K. Jones/D. L. Sours

R. A. Rochette

J. J. Sutey

2 Westinghouse Hanford Company

L. K. Aldrich II

R. 0. Budd

42 Pacific Northwest Laboratory

W. J. Bair

L. W. Brackenbush

G. W. R. Endres

S. K. Ennor

T. H. Essig

L. G. Faust

J. J. Fix

D. E. Hadlock

D. L. Haggard

G. R. Hoenes

L. A. Rathbun

W. D. Reece

J. M. Selby (15)

K. L. Soldat

K. L. Swinth (5)

R. J. Traub

Health Physics Department Library

Publishing Coordination (2)

Technical Report Files (5) 


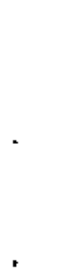

